\title{
Remedial Action Plan and Site DESIGN FOR STABILIZATION OF THE INACTIVE URANIUM MILL TAILINGS Sites at Slick Rock, Colorado
}

\section{Remedial Action Selection Report}

\author{
Preliminary Final
}

March 1994

\author{
Appendix B of the \\ Cooperative Agreement \\ No. DE-FC04-81AL16257 \\ DISCLAIMER
}

This report was prepared as an account of work sponsored by an agency of the United States Government. Neither the United States Government nor any agency thereof, nor any of their employees, makes any warranty, express or implied, or assumes any iegal liability or responsibility for the accuracy, completeness, or usefulness of any information, apparatus, product, or process disclosed, or represents that its use would not infringe privately owned rights. Reference herein to any specific commercial product, process, or service by trade name, trademark, manufacturer, or otherwise does not necessarily constitute or imply its endorsement, recommendation, or favoring by the United States Government or any agency thereof. The views and opinions of authors expressed herein do not necessarily state or reflect those of the United States Government or any agency thereof. 


\section{INTENDED FOR PUBLIC RELEASE}

This report has been reproduced from the best available copy. Available in paper copy and microfiche.

Number of pages in this report: 102

DOE and DOE contractors can obtain copies of this report from:

Office of Scientific and Technical Information

P.O. Box 62

Oak Ridge, TN 37831

(615) 576-8401

This report is publicly available from:

National Technical Information Service

Department of Commerce

5285 Port Royal Road

Springfield, VA 22161

(703) $487-4650$ 


\section{REMEDIAL ACTION PLAN AND SITE DESIGN FOR STABILIZATION}

OF THE INACTIVE URANIUM MILL TAILINGS SITES

AT SLICK ROCK, COLORADO

Preliminary Final

March 1994

Prepared for

U.S. Department of Energy UMTRA Project Office Albuquerque, New Mexico

Prepared by Jacobs Engineering Group Inc. Albuquerque, New Mexico 


\section{EXECUTIVE SUMMARY}

\section{INTRODUCTION}

The Slick Rock uranium mill tailings sites are located near the small town of Slick Rock, in San Miguel County, Colorado. There are two designated Uranium Mill Tailings Remedial Action (UMTRA) Project sites at Slick Rock: the Union Carbide (UC) site and the North Continent (NC) site. Both sites are adjacent to the Dolores River. The UC site is approximately 1 mile (mi) (2 kilometers $[\mathrm{km}]$ ) downstream of the NC site. Contaminated materials cover an estimated 55 acres (ac) (22 hectares [ha]) at the UC site and 12 ac (4.9 ha) at the NC site. The sites contain former mill building concrete foundations, tailings piles, demolition debris, and areas contaminated by windblown and waterborne radioactive materials. The total estimated volume of contaminated materials is approximately 620,000 cubic yards $\left(\mathrm{yd}^{3}\right)\left(470,000\right.$ cubic meters $\left[\mathrm{m}^{3} \mathrm{]}\right)$. in addition to the contamination at the two processing site areas, four vicinity propertifs were contaminated. Contamination associated with the UC and NC sites has leached intci ground water.

\section{REMEDIAL ACTION}

Pursuant to the requirements of the Uranium Mill Tailings Radiation Control Act (UMTRCA), the proposed remedial action plan (RAP) will satisfy the U.S. Environmental Protection Agency (EPA) standards (40 CFR Part 192 (1993)) for cleanup, stabilization, and control of the residual radioactive materials (RRM) (tailings and other contaminated materials) at the proposed disposal site at Burro Canyon. The requirements for control of the RRM (Subpart A) will be satisfied by the construction of an engineered disposal cell.

The proposed remedial action will consist of relocating the uranium mill tailings, contaminated vicinity property materials, demolition debris, and windblown/waterborne materials to a permanent repository at the proposed Burro Canyon disposal cell. The site is located approximately 5 road $\mathrm{mi}(8 \mathrm{~km})$ northeast of the mill sites on land currently administered by the Bureau of Land Management. The proposed disposal site was selected based on public input, environmental considerations, and regulatorily acceptable design opportunities.

The proposed disposal cell will be partially below-grade. The base of the cell will be excavated into the low-permeability claystones and mudstones to prepare for placement of the contaminated material. The mudstone/claystone will provide a natural impermeable barrier from the base of the pit to approximately 1.5 meters $(\mathrm{m})$ up the side wall to form a continuous saucer-shaped bottom and side liner. The RRM will be covered with a 5.2-foot (ft) $(1.6-\mathrm{m})$ cover on the topslopes and a 5.5-ft $(1.7-\mathrm{m})$ cover on the sideslopes. Both the topslope and sideslope covers will include a radon/infiltration barrier, layers to protect the barrier against frost penetration and the buildup of moisture, a sand and gravel bedding/drainage layer, and a rock erosion protection layer at the surface of the cell. 


\section{DESIGN ANALYSES}

This proposed RAP incorporates the results of detailed investigation of geologic, geomorphic, and seismic conditions at the proposed disposal site. The proposed disposal site will be geomorphically stable (i.e., against gully erosion in the cell vicinity, or from slope failure). Seismic design parameters were developed for the geotechnical analyses of the proposed cell. Cell stability was analyzed to ensure long-term performance of the disposal cell in meeting design standards, including slope stability, settlement, and liquefaction potential.

The proposed cell cover and erosion protection features were also analyzed and designed to protect the RRM agzinst surface water and wind erosion. The location of the proposed cell precludes the need for permanent drainage or interceptor ditches. Rock to be used on the cell top-, side-, and toeslopes was sized to withstand probable maximum precipitation events.

The requirements for radon emissions of 40 CFR Part 192 (1993), Subpart A, will be met with the disposal cell's $2-\mathrm{ft}(0.6-\mathrm{m})$ thick fine-grained radon barrier.

\section{GROUND WATER COMPLIANCE}

To achieve compliance with the proposed EPA ground water protection standards, the U.S. Department of Energy (DOE) proposes a supplemental standard that will ensure protection of human health and the environment. This standard applies to the ground water in the uppermost aquifer, defined as the low-yield ground water in the upper sandstone unit of the Burro Canyon Formation. The proposed disposal cell foundation will be separated from the uppermost aquifer by a thick layer ( 25 to $75 \mathrm{ft}$ [7.6 to $23 \mathrm{~m}$ ]) of low-permeability mudstone. Ground water in the underlying lithologic units is protected from potential siterelated contamination by low-permeability mudstone/claystone units and upward vertical hydraulic gradients that inhibit the downward migration of water. This supplemental standard will be narrative and will not include numerical concentration limits for the hazardous constituents identified in the RRM at the Slick Rock sites. In addition, a point of compliance has not been proposed. Ground water monitoring would not be effective at the Burro Canyon disposal site and is therefore not proposed, because insufficient yield in the uppermost aiquifer will preclude its future use. The only point of exposure that could potentially affect human health or the environment would be surface seepage at the base of the disposal cell mesa. In lieu of ground water monitoring, the DOE will conduct compliance monitoring through inspections to locate surface expressions of seepage at and in the vicinity of the Burro Canyon disposal site. These visual inspections will include looking for physical evidence of mineralization, phreatophyte vegetation, and the presence of saturated zones at sandstone outcrops. 


\section{TABLE OF CONTENTS}

Section

Page

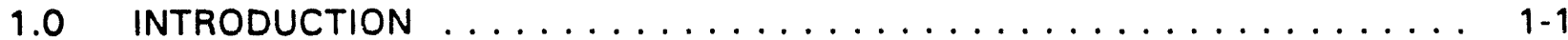

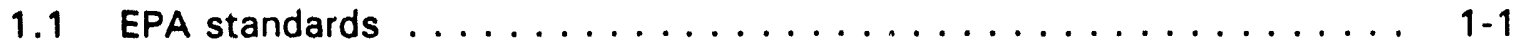

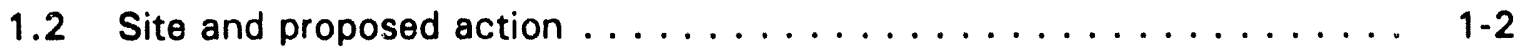

1.2.1 History .......................... 1-2

1.2 .2 Location .......................... 1-2

1.2.3 Contaminated materials . . . . . . . . . . . . . . 1-4

1.2 .4 Remedial action ........................ 1-4

1.3 Scope and content .......................... 1-10

1.4 Remedial action selection organization $\ldots \ldots \ldots \ldots \ldots \ldots \ldots \ldots \ldots \ldots$

1.5 Collateral documents ...................... 1-11

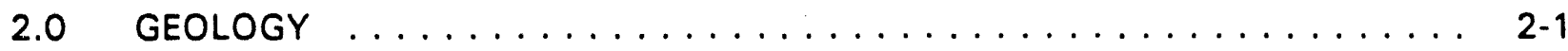

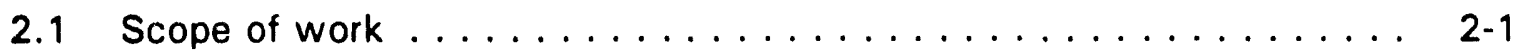

2.2 Regional geology ......................... $2-1$

2.2.1 Regional physiography .................. 2-2

2.2 .2 Stratigraphic setting .................. 2-2

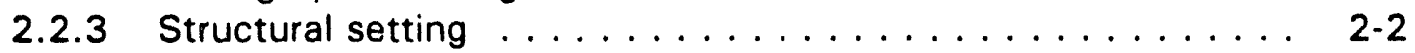

2.2.4 Seismotectonics ..................... 2-3

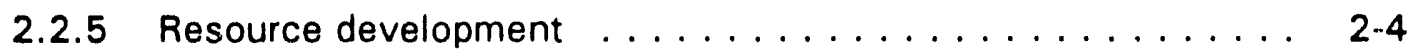

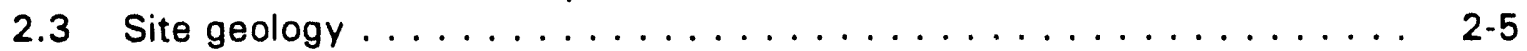

2.3.1 Bedrock geology .................... 2-5

2.3 .2 Surficial geology ..................... $2-5$

2.3.3 Geomorphology ..................... 2-5

2.4 Geologic stability ......................... $2-6$

2.4.1 Geomorphic stability . . . . . . . . . . . . . 2-6

2.4 .2 Seismotectonic stability ................ 2-7

2.5 Geologic suitability . . . . . . . . . . . . . . . . . . 2-8

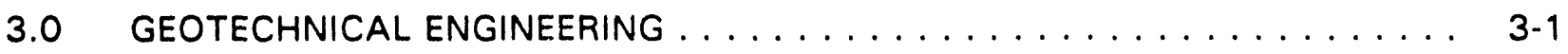

3.1 Introduction .......................

3.2 Site and material characterization . . . . . . . . . . . . . . $3-1$

3.2.1 Geotechnical investigation ................. 3-1

3.2 .2 Testing program .................... 3.2

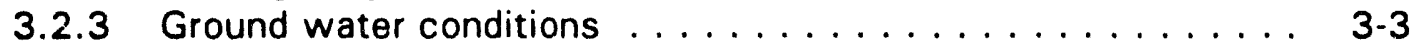

3.2 .4 Site stratigraphy .................... 3.4

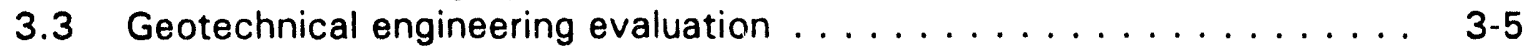

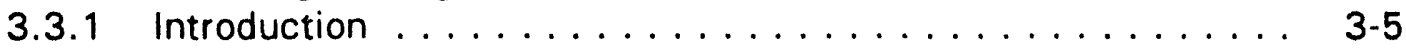

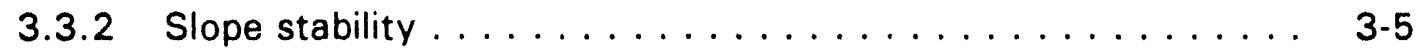

3.3.3 Settlement . . . . . . . . . . . . . . . . 3-7

3.3.4 Liquefaction potential . . . . . . . . . . . . 3-7

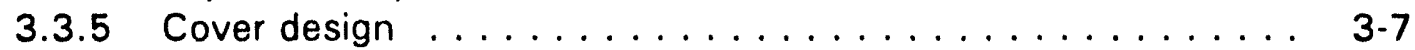

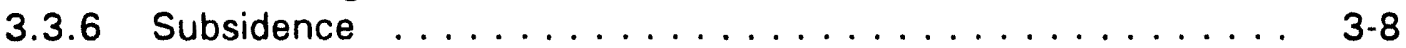

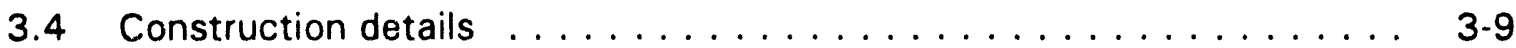

3.4.1 Construction methods and features . . . . . . . . . . . . 3-9 
TABLE OF CONTENTS (Continued)

Section

Page

3.4.2 Testing and inspection . . . . . . . . . . . . . . . 3-9

3.4.3 Construction activities and construction sequence . . . . . 3-10

3.5 Summary ......................... 3.13

4.0 SURFACE WATER HYDROLOGY AND EROSION PROTECTION $\ldots \ldots \ldots$

4.1 Hydrologic description and remedial action design . . . . . . . . . 4-1

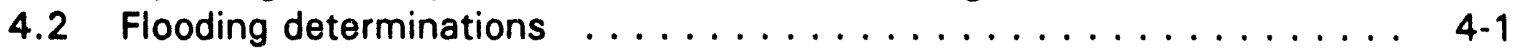

4.2.1 Probable maximum precipitation . . . . . . . . . . . 4-1

4.2.2 Infiltration losses ................... 4-1

4.2.3 Time of concentration .................. 4.3

4.2.4 Rainfall distributions - probable maximum precipitation ..... 4-3

4.2.5 Computation of probable maximum flood ............ 4-3

4.3 Flow depth and velocities .................... 4.3

4.3.1 Adjacent waterways . . . . . . . . . . . . . 4-3

4.3.2 Drainage ditches ..................... 4.4

4.3.3 Top and sides of the embankment ............. 4-4

4.4 Erosion protection ......................... 4.4

4.4.1 Topslopes ....................... 4.4

4.4 .2 Sideslopes . . . . . . . . . . . . . . . . 4.4

4.4.3 Toe and sides of the embankment ............ 4-5

4.5 Rock durability ......................... 4-5

4.6 Quality control testing and inspection for erosion protection ...... . 4-5

4.7 Upstream dam failures ..................... 4.5

4.8 Summary ......................... 4.6

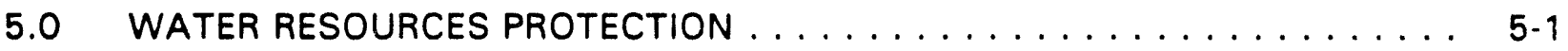

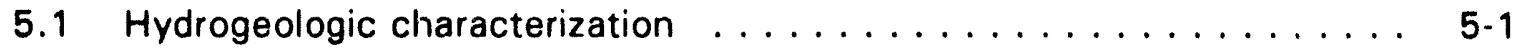

5.1 .1 Identification of hydrogeologic units ........... 5-1

5.1.2 Hydraulic and transport properties .............. 5-8

5.1.3 Geochemical conditions ................... 5-10

5.1 .4 Characterization methods ............... 5-12

5.1 .5 Water use ......................... 5-16

5.2 Conceptual design features for water resources protection . . . . . 5-17

5.3 Disposal ........................... 5-18

5.3.1 Ground water protection standard for disposal . . . . . . . . . 5-18

5.3.2 Narrative supplemental standard . . . . . . . . . . . . . . . . 5-22

5.3.3 Point of exposure ... . . . . . . . . . . . . . . . . . . 5-24

5.4 Performance assessment and demonstration . . . . . . . . . . 5-28

5.5 Ground water monitoring . . . . . . . . . . . . . . . . 5-29

5.6 Ground water cleanup . . . . . . . . . . . . . . . . . . 5 5-29

5.6.1 Ground water cleanup standard . . . . . . . . . . . . . . 5-29

5.6.2 Cleanup demonstration ................... 5-30

5.6.3 Cleanup monitoring program ................ 5-30 
TABLE OF CONTENTS (Continued)

Section

Page

5.7 Water resources protection strategy summary . . . . . . . . . 5-30

6.0 RADON ATTENUATION AND SITE CLEANUP $\ldots \ldots \ldots \ldots \ldots \ldots \ldots \ldots \ldots$

6.1 Introduction .......................... 6.1

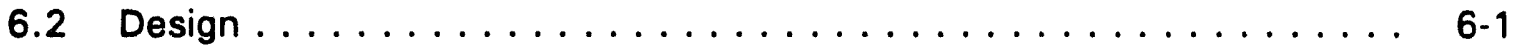

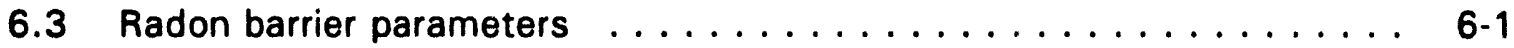

6.3.1 Long-term moisture . . . . . . . . . . . . . . . . . . 6-2

6.3.2 Radon diffusion . . . . . . . . . . . . . . . . . . 6-2

6.3.3 Radon emanation ...................... 6-3

6.3.4 Dry densities and porosities ................. 6-3

6.3 .5 Layer thickness ..................... 6-3

6.3.6 Radium-226 concentrations . . . . . . . . . . . . 6. 6-4

6.3.7 Ambient radon concentration ... . . . . . . . . . . . 6. 6-4

6.4 Evaluation of radon barrier . . . . . . . . . . . . . . . . 6.4

6.5 Site cleanup .......................... 6-5

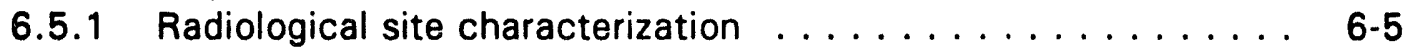

6.5.2 Standards for cleanup . . . . . . . . . . . . . . . 6-7

6.5 .3 Verification of cleanup ................... 6-7

6.6 Summary and conclusion ...................... 6-8

7.0 LIST OF CONTRIBUTORS $\ldots \ldots \ldots \ldots \ldots \ldots \ldots \ldots \ldots \ldots \ldots$

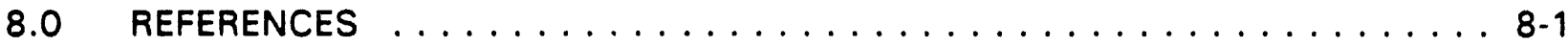

ATTACHMENT 1 SPECIFICATIONS, DESIGN DRAWINGS, INFORMATION FOR REVIEWERS, INFORMATION FOR BIDDERS, CALCULATIONS AND REPORTS, COST ESTIMATES

ATTACHMENT 2 GEOLOGY REPORT

ATTACHMENT 3 GROUND WATER HYDROLOGY REPORT

ATTACHMENT 4 WATER RESOURCES PROTECTION STRATEGY 


\section{LIST OF FIGURES}

\section{Figure}

Page

1.1 Locations of the Union Carbide and North Continent UMTRA sites near Slick Rock, Colorado ............................... 1-3

1.2 Location of the Union Carbide UMTRA site near Slick Rock, Colorado . . . . . 1-5

1.3 Location of the North Continent UMTRA site near Slick Rock, Colorado . . . 1-6

1.4 Burro Canyon site location ... . . . . . . . . . . . . . . . . . 1-7

1.5 Disposal cell for the Slick Rock tailings, Slick Rock, Colorado . . . . . . . . . . 1-8

1.6 Cross sections of the disposal cell at the Burro Canyon disposal site near Slick Rock, Colorado ... . . . . . . . . . . . . . . . . . . . . . . . . . . 1-9

4.1 Drainage systems, Burro Canyon site area, Slick Rock, Colorado . . . . . . . 4-2

5.1 Monitor well location map of the UC and NC processing sites, Slick Rock, Colorado . . . . . . . . . . . . . . . . . . . . . . . . . . . . . 5-2

5.2 Stratigraphic cross section at the UC and NC processing sites, Slick Rock, Colorado . . . . . . . . . . . . . . . . . . . . . . . . . . . . . 5 5-3

5.3 Monitor well location map and north-south $\left(A-A^{\prime}\right)$ cross section at the Burro Canyon disposal site, Colorado ... . . . . . . . . . . . . . . . . . . 5 5-6

5.4 Stratigraphy along the north-south (A-A') cross section, Slick Rock, Colorado . . . . . . . . . . . . . . . . . . . . . . . . . . . 5-7

5.5 Structural map of upper sandstone unit of Burro Canyon Formation . . . . . 5-25

5.6 Representative diagrammatic section of strata of Burro Canyon Formation . . 5-26

6.1 Areal extent of Ra-226 soil concentrations exceeding $5 \mathrm{pCi} / \mathrm{g}$ at Slick Rock tailings sites, Slick Rock, Colorado . . . . . . . . . . . . . . . . . . . . 6-6 


\section{LIST OF TABLES}

Table

Page

1.1 Contaminated material volumes at the Slick Rock processing sites, Colorado .............................. 1-4

1.2 Relationship between design details, criteria, and supporting

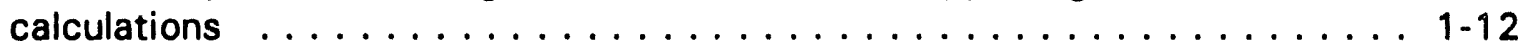

3.1 Results of slope stability analysis $\ldots \ldots \ldots \ldots \ldots \ldots \ldots$ 3-6

3.2 Cover components and their function $\ldots \ldots \ldots \ldots \ldots \ldots$

4.1 Rock size requirements and layer thickness for the Burro Canyon disposal cell .......................... 4-5

5.1 Average hydraulic properties at the processing sites . . . . . . . . . 5-8

5.2 Average hydraulic properties at the disposal site . . . . . . . . . . . 5-9

5.3 Summary of hazardous constituents identified at the Slick Rock processing sites ......................... 5-20

6.1 Background radioactivity and radiological conditions at the Slick Rock sites ............................. 6-5 
LIST OF ACRONYMS AND ABBREVIATIONS

\section{Acronym}

ac

ALARA

ASTM

$\mathrm{CDH}$

cm

DOE

EPA

FE

$\mathrm{ft}$

$\mathrm{ft}^{3} / \mathrm{s} / \mathrm{ft}$

$\mathrm{ft} / \mathrm{yr}$

$\mathrm{g}$

$\mathrm{g} / \mathrm{cm}^{3}$

gpd

ha

in

$\mathrm{km}$

L/s

$\mathrm{m}$

$m^{2}$

$\mathrm{m}^{3}$

$\mathrm{m}^{3} / \mathrm{s} / \mathrm{m}$

$\mathrm{MCL}$

ME

$\mathrm{mg} / \mathrm{L}$.

$\mathrm{mi}$

$\mathrm{mm}$

$\mu \mathrm{R} / \mathrm{hr}$

MSL

NC

NRC

pCi/g

pCi/L

$\mathrm{pCi} / \mathrm{m}^{2} \mathrm{~s}$

PHA

PMP

POC

QA

QC

Ra-226

RAC

RAP

RAS

Rn-222

\section{Definition}

acre

as low as reasonably achievable

American Society for Testing and Materials

Colorado Department of Health

centimeter

U.S. Department of Energy

U.S. Environmental Protection Agency

floating earthquake

feet

cubic feet per second per foot

feet per year

gravity

grams per cubic centimeter

gallons per day

hectare

inch

kilometer

liters per second

meter

square meter

cubic meter

cubic meter per second per meter

maximum concentration limit

maximum earthquake

milligrams per liter

mile

millimeter

microroentgens per hour

mean sea level

North Continent

U.S. Nuclear Regulatory Commission

picocuries per gram

picocurie per liter

picocuries per square meter per second

peak horizontal acceleration

probable maximum precipitation

point of compliance

quality assurance

quality control

radium-226

Remedial Action Contractor

remedial action plan

remedial action selection

radon-222 


\section{LIST OF ACRONYMS AND ABBREVIATIONS (Concluded)}

$\begin{array}{ll}\text { Acronym } & \text { Definition } \\ \text { RRM } & \text { residual radioactive materials } \\ \text { SF\&C } & \text { standard format and content } \\ \text { SPEAR } & \text { Software Program for Environmental Analysis and Reporting } \\ \text { SRP } & \text { standard review plan } \\ T_{C} & \text { time of concentration } \\ \text { TAC } & \text { Technical Assistance Contractor } \\ \text { TAD } & \text { Technical Approach Document } \\ \text { TDS } & \text { total dissolved solids } \\ \text { TER } & \text { technical evaluation reports } \\ \text { Th-230 } & \text { thorium-230 } \\ \text { UC } & \text { Union Carbide } \\ \text { Umetco } & \text { Union Carbide Corporation } \\ \text { UMTRA } & \text { Uranium Mill Tailings Remedial Action } \\ \text { UMTRCA } & \text { Uranium Mill Tailings Radiation Control Act } \\ \text { Yd } & \text { cubic yards }\end{array}$




\subsection{INTRODUCTION}

The inactive uranium mill tailings sites near Slick Rock, Colorado, were designated as 2 of 24 abandoned uranium tailings sites to be remediated by the U.S. Department of Energy (DOE) under the Uranium Mill Tailings Radiation Control Act (UMTRCA) of 1978 (42 USC $\$ 7901$ et seq.). The UMTRCA requires that the U.S. Nuclear Regulatory Commission (NRC) concur with the DOE's remedial action plan (RAP) and certify that the remedial action complies with the standards promulgated by the U.S. Environmental Protection Agency (EPA). The RAP, which includes this remedial action selection (RAS) report, serves two purposes. First, it describes the activities proposed by the DOE to accomplish long-term stabilization and control of residual radiosctive materials (RRM) at the inactive uranium processing sites near Slick Rock, Colorado. Second, this document and the remainder of tire RAP, upon concurrence and execution by the DOE, the state of Colorado, and the NRC, will become Appendix B of the cooperative agreement between the DOE and the state of Colorado.

The DOE objective in preparing this RAP is to comply with EPA regulations in Subparts A through C of 40 CFR Part 192 (1993). All remedial action planning and design considerations contained herein reflect the incorporation of this regulatory guidance. Therefore, by performing all remedial action activities in accordance with the design presented in this RAP, the DOE will meet the standards of 40 CFR Part 192. These regulations are summarized in Section 1.1.

\section{$1.1 \quad$ EPA STANDARDS}

As required by Title I of the UMTRCA, remedial action at the Slick Rock sites must comply with regulations established by the EPA in 40 CFR Part 192, Subparts $A$ through $C$. The regulations are summarized as follows:

- The disposal site shall be designed to stabilize and control the tailings and other RRM for 1000 years to the extent reasonably achievable and, in any case, for at least 200 years (40 CFR $\$ 192.02$ (b)).

- The disposal site design shall prevent radon-222 (Rn-222) flux from RRM into the atmosphere from exceeding 20 picocuries per square meter per second $\left(\mathrm{pCi} / \mathrm{m}^{2} \mathrm{~s}\right)$, or from increasing the annual average concentration of Rn-222 in air by more than 0.5 picocurie per liter (pCi/L) (40 CFR $\$ 192.02(b))$.

- The remedial action shall be conducted to provide reasonable assurance that the concentration of radium-226 (Ra-226) in land, averaged over 100 square meters $\left(\mathrm{m}^{2}\right)$, does not exceed the background level by more than 5 picocuries per gram $(\mathrm{pCi} / \mathrm{g})$, averaged over the first 15 centimeters $(\mathrm{cm})$ of soil below the surface; and $15 \mathrm{pCi} / \mathrm{g}$ averaged over $15-\mathrm{cm}$-thick layers of soil more than $15 \mathrm{~cm}$ below the surface, as a result of any residual radioactive materials at any designated processing site (40 CFR $\$ 192.12(a))$. 
In September 1985, the U.S. Court of Appeals for the Tenth Circuit remanded the ground water standards contained in 40 CFR \$192.2(a)(2)-(3). The court stipulated that the EPA promulgate new ground water standards of a general nature applicable to all Title I uranium mill sites.

In September 1987, the EPA issued proposed standards in response to the court remand. These proposed standards apply to disposal of the tailings (Subpart A), cleanup of ground water contaminated by the former mills (Subpart B), and implementation of the remedial action (Subpart C).

\subsection{SITE AND PROPOSED ACTION}

\subsubsection{History}

The Slick Rock tailings sites consist of two tailings piles: one each at the Union Carbide (UC) site and the North Continent (NC) site. Both sites are currently owned by the Union Carbide Corporation (Umetco). The UC mill began operation in 1957 and processed ore mined from the surrounding area. Upgraded material from the UC site was trucked to the UC mill in Rifle, Colorado. The NC mill site dates to 1931, when it was owned by Shattuck Chemical Company. The federal government acquired control of the site through the Union Mines Development Corporation with the specific purpose of supplying uranium and vanadium for the Manhattan Project. Umetco became the owner of the site in 1957. Except for some concrete foundations, all the mill buildings have been removed from the UC site. The former recreational building and dormitory remain adjacent to the site. Mobile homes have been removed from a trailer park area off the site, leaving concrete pads. All structures (including foundations) have been removed from the NC site. Both tailings piles were covered with soil and are at least partially vegetated.

\subsubsection{Location}

Both the UC and NC tailings sites are located in San Miguel County, Colorado (Figure 1.1). The tailings sites are next to the Dolores River and are surrounded by steep, juniper-covered hillsides and cliffs of the Dolores River Canyon. The tai: :ngs sites are 5500 feet ( $\mathrm{ft})(1700$ [m] meters) above mean sea level (MSL), while the surrounding hillsides reach $6500 \mathrm{ft}(2000 \mathrm{~m})$ above MSL. The UC tailings site is approximately 1 mile (mi) (2 kilometers $[\mathrm{km}]$ ) downstream of the NC tailings site.

The sites are arid with a mean annual precipitation of 9 inches (in) [200 millimeters $(\mathrm{mm})$ ]. The dominant land use in the area is grazing. A gas sweetener plant is adjacent to the UC tailings pile. In the past, mining was common in the area and there are now numerous abandoned mines and mining roads in the area. The area is sparsely populated; six people live within $1.6 \mathrm{mi}$ $(2.6 \mathrm{~km})$ of the site. 


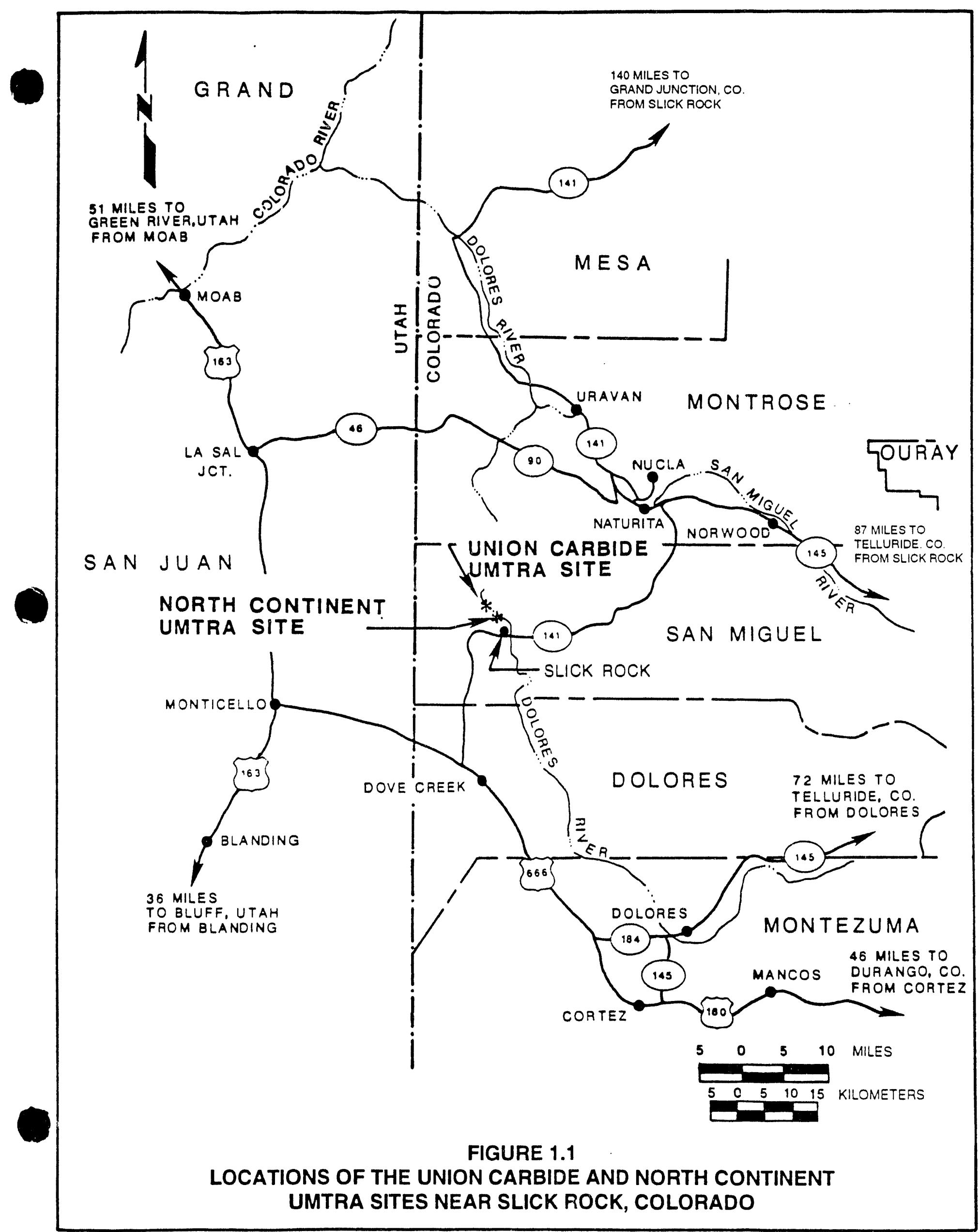




\subsubsection{Contaminated materials}

The UC tailings site consists of the tailings pile, mill site, mill site demolition debris, and windblown/waterborne contaminated areas (Figure 1.2). The tailings pile and the surrounding contaminated land cover 55 acres (ac) $(22$ hectares (hal). Approximately 536,000 cubic yards $\left(\mathrm{yd}^{3}\right)\left(410,000\right.$ cubic meters $\left.\left[\mathrm{m}^{3}\right]\right)$ of contaminated material at the UC site are distributed as shown in Table 1.1.

Table 1.1 Contaminated material volumes at the Slick Rock processing sites, Colorado

\begin{tabular}{|c|c|c|}
\hline \multirow[b]{2}{*}{ Location/source } & \multicolumn{2}{|c|}{ Volume } \\
\hline & $\left(y d^{3}\right)$ & $\left(m^{3}\right)$ \\
\hline \multicolumn{3}{|l|}{ UC site } \\
\hline Tailings & 296,000 & 226,000 \\
\hline Contaminated materials & 234,900 & 179,600 \\
\hline Demolition debris & 2,850 & 2,180 \\
\hline Subtotal & 533,750 & 407,780 \\
\hline \multicolumn{3}{|l|}{ NC site } \\
\hline Contaminated soil/tailings & 84,800 & 64,800 \\
\hline Demolition debris & 155 & 119 \\
\hline Subtotal & 84,955 & 64,919 \\
\hline Totals (rounded) & 618,700 & 472,700 \\
\hline
\end{tabular}

The NC tailings site consists of the tailings pile and windblown contaminated areas (Figure 1.3). The tailings pile is difficult to differentiate from the surrounding contaminated land. Approximately 12 ac (4.9 ha) are contaminated, with approximately $85,000 \mathrm{yd}^{3}\left(65,000 \mathrm{~m}^{3}\right)$ of contaminated materials distributed as shown in Table 1.1.

\subsubsection{Remedial action}

The proposed remedial action consists of removing all contaminated material from both former mill sites to the proposed Burro Canyon disposal site, located approximately $2.5 \mathrm{mi}(4.0 \mathrm{~km})$ east of the UC and NC processing sites in Sections 21 and 28, Township 44 North, Range 18 West (Figure 1.4). Contaminated materials will be transported over an approximately $6-\mathrm{mi}(10-\mathrm{km})$ haul route. The approximately $1-\mathrm{mi}(2-\mathrm{km})$ access road from Colorado State Highway 141 to the Burro Canyon disposal site will require upgrading, as will the access road between the NC site and Highway 141. The remainder of the haul route is on state- and county-maintained roads.

Figures 1.5 and 1.6 present the proposed disposal cell. Disposal will consist of constructing a 12-ac (4.9-ha) engineered cell partially below-grade. The disposal cell will be situated to optimally utilize the saddle and mesa topography at the Burro Canyon site. The cell will be shaped to avoid or minimize 


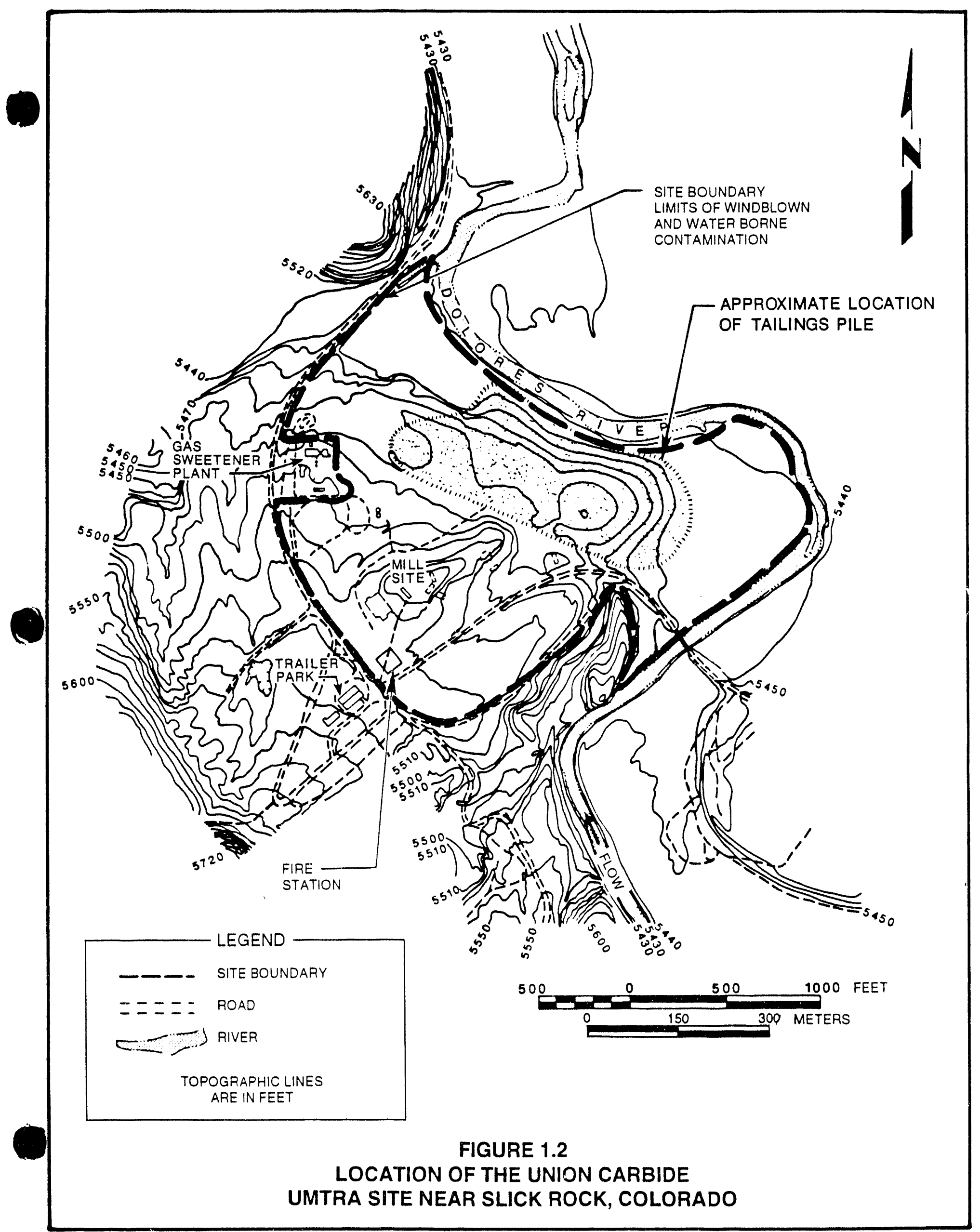




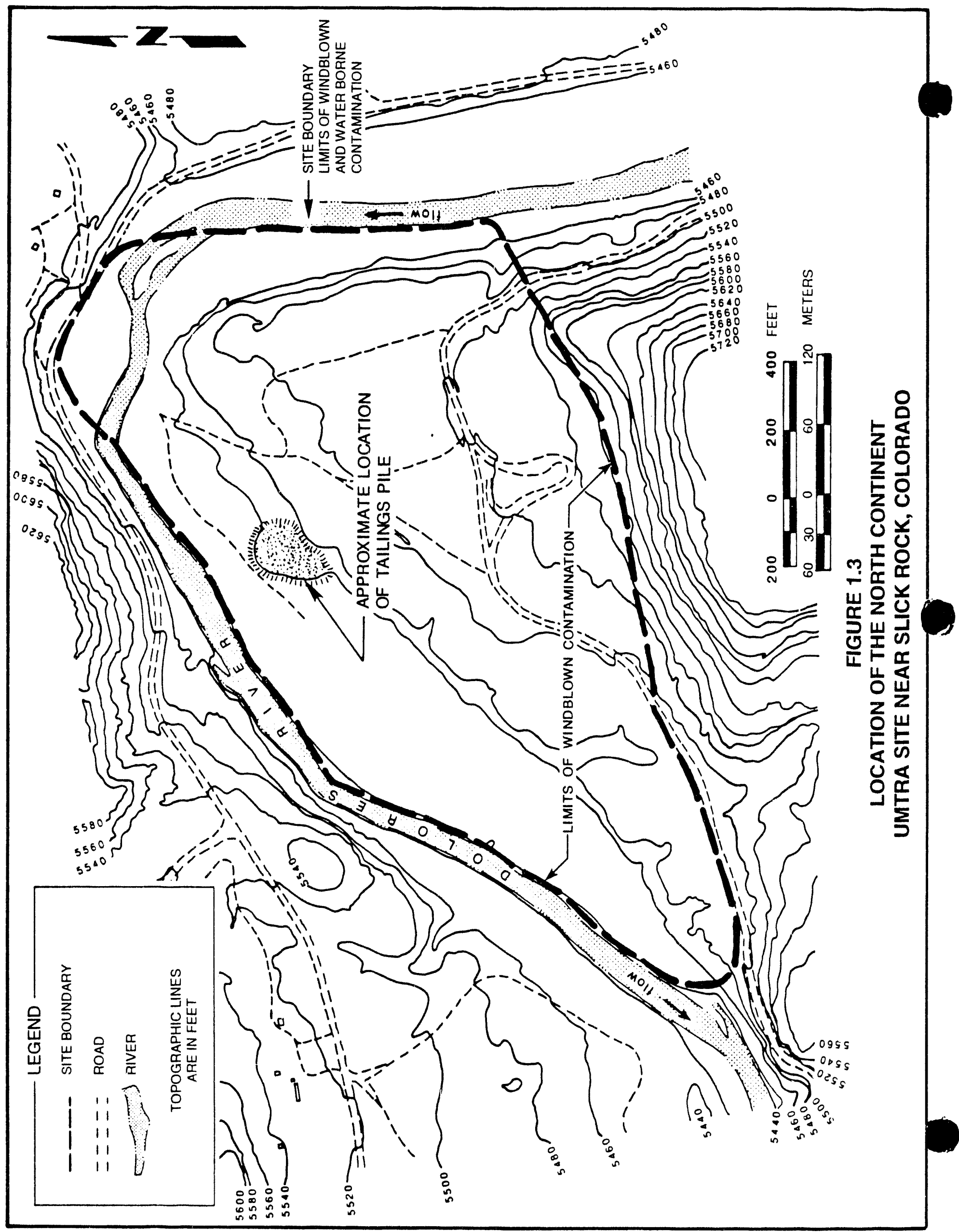




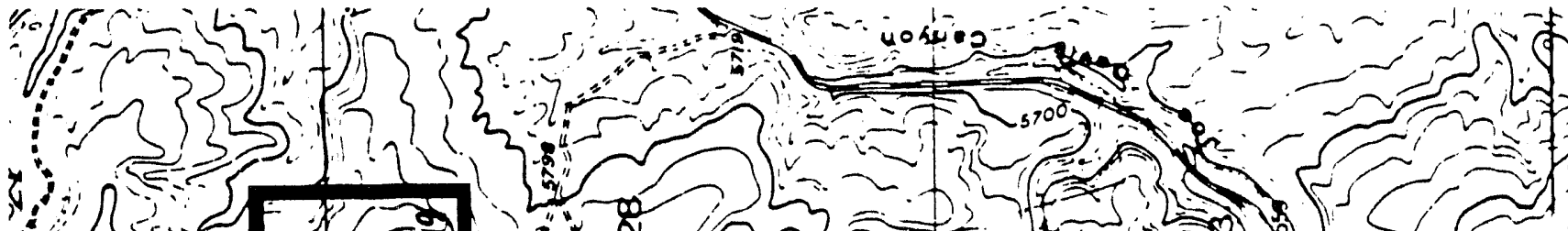

证

(1)

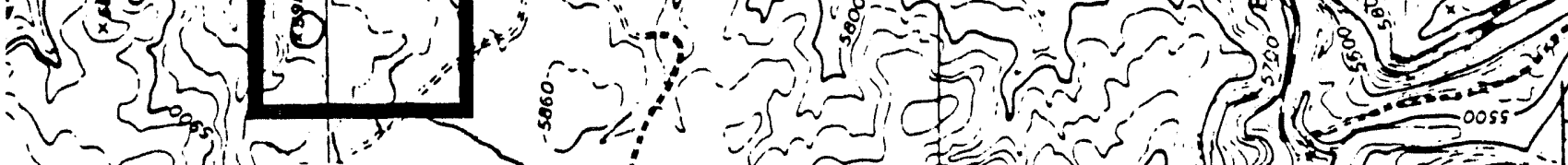

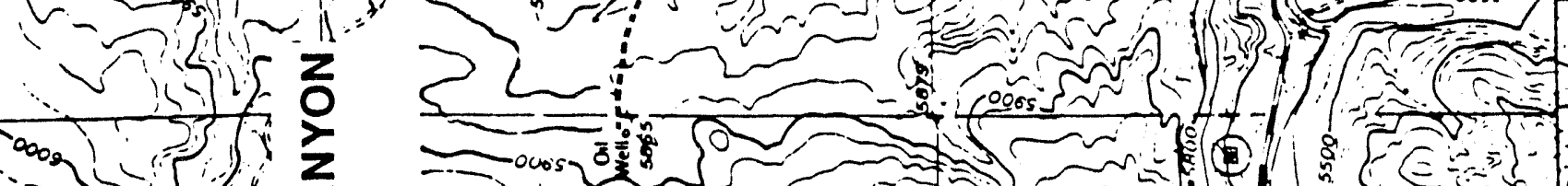

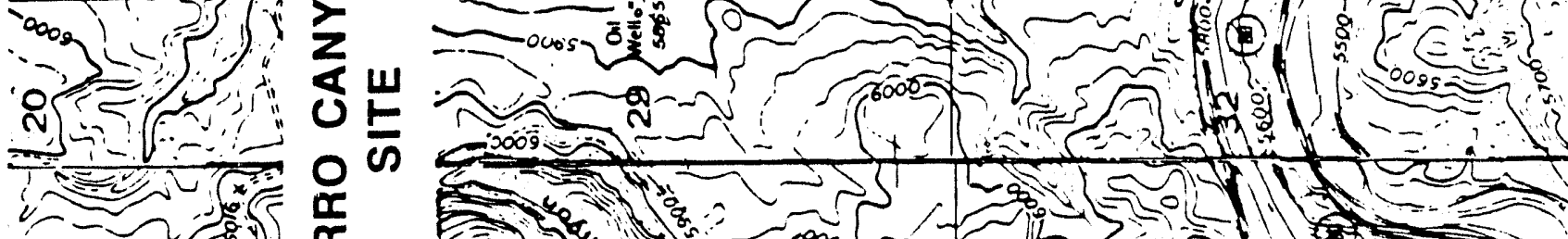

O-009

(1)

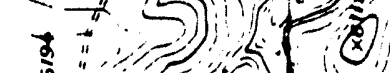

\section{(1)} 过Line

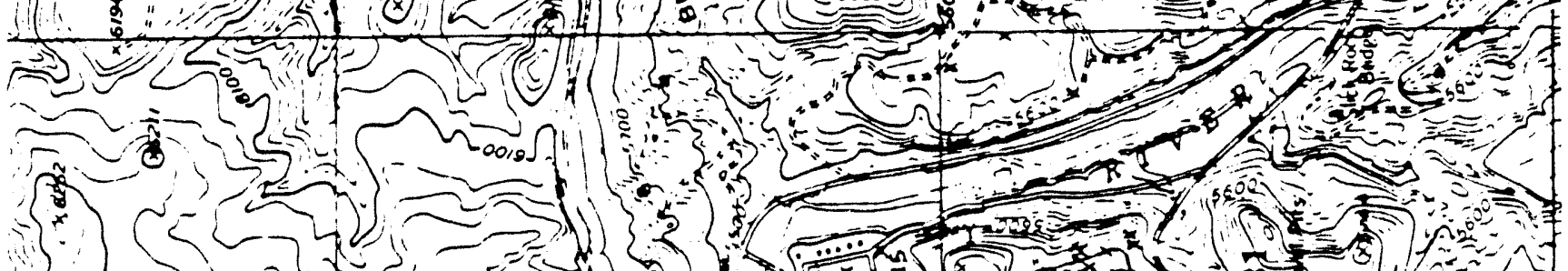

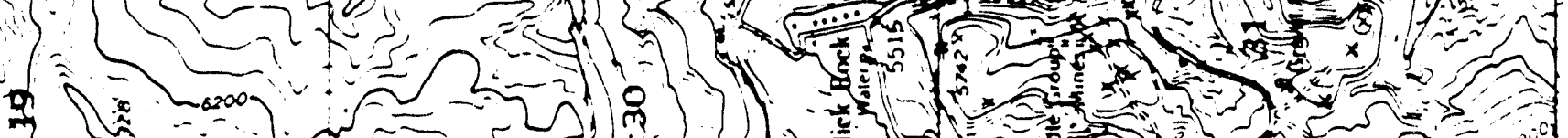

2.

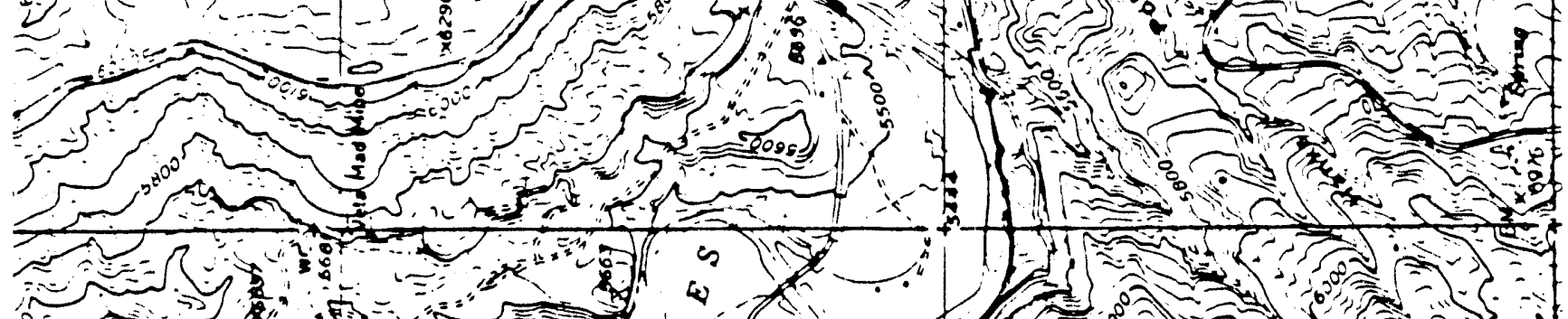
Non 


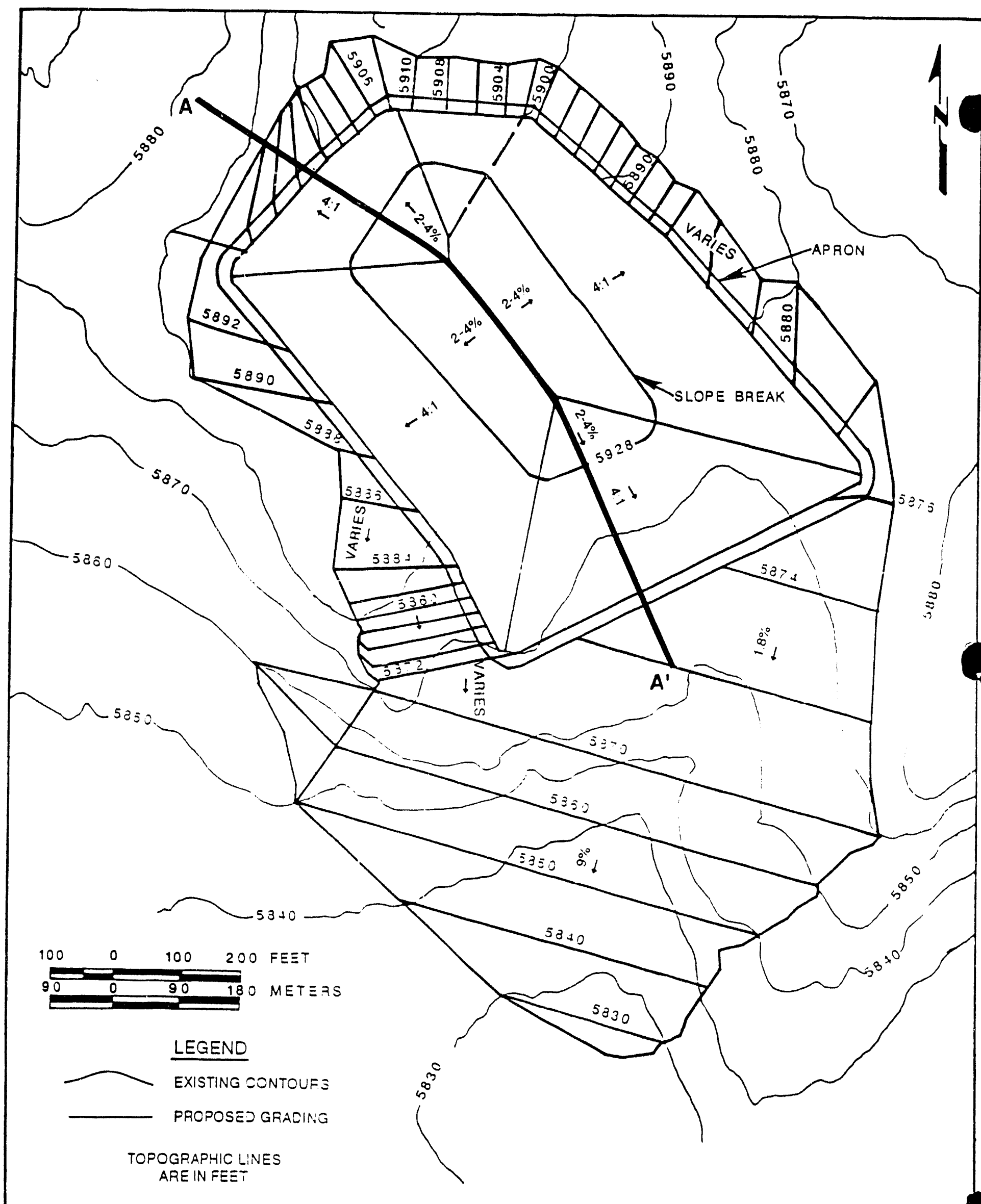

FIGURE 1.5

DISPOSAL CELL FOR THE SLICK ROCK TAILINGS SLICK ROCK, COLORADO 


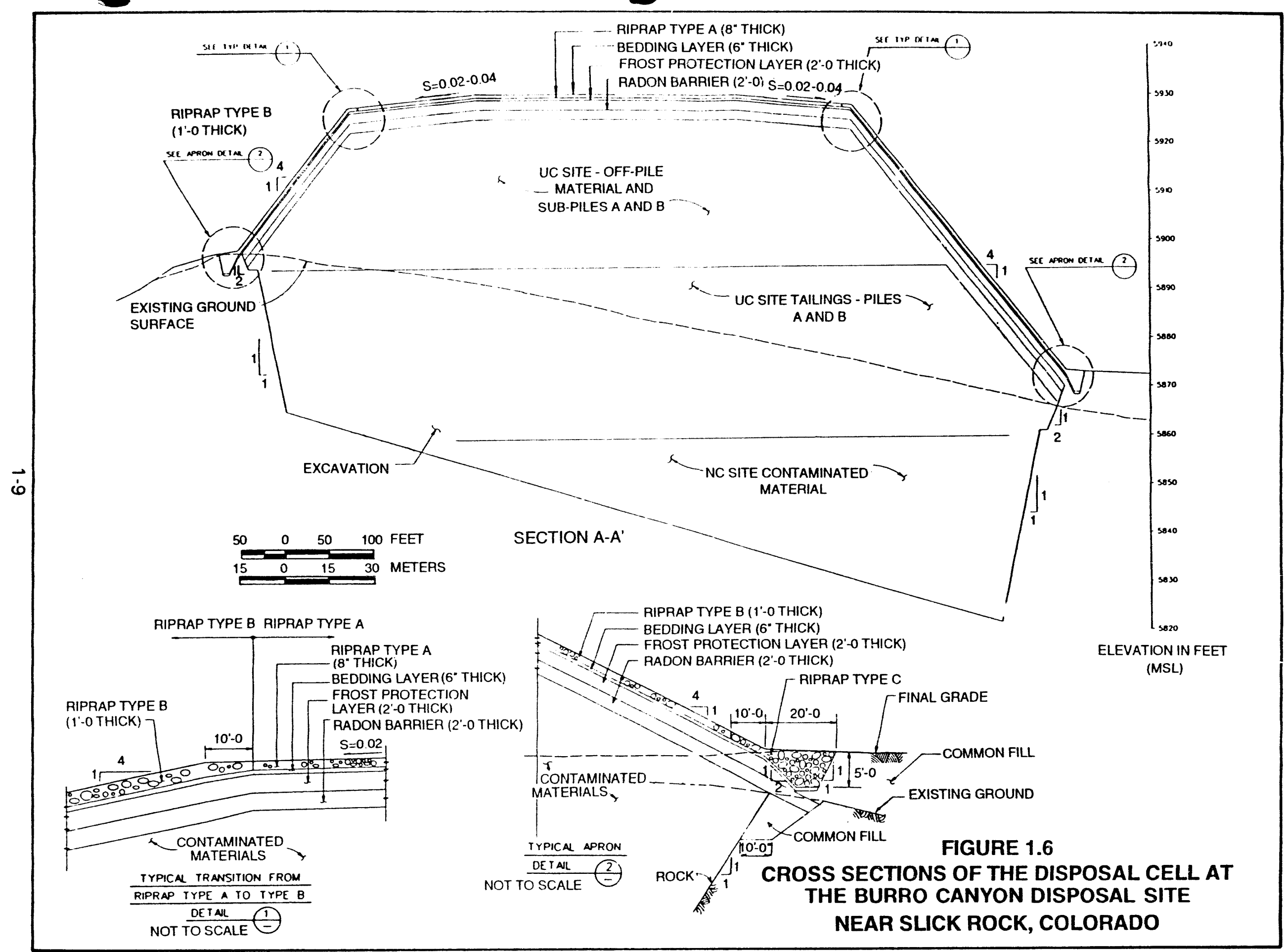


detrimental effects of surface water drainage and potential geomorphic change. To this end, the edge of the tailings and contaminated materials in the disposal cell will be no closer than $100 \mathrm{ft}(30 \mathrm{~m})$ to the edge of the mesa, nor will it extend outside the perimeter shown in Figure 1.5.

The disposal cell will hold approximately $620,000 \mathrm{yd}^{3}\left(470,000 \mathrm{~m}^{3}\right)$ of contaminated material and cover an area approximately $610 \mathrm{ft}(190 \mathrm{~m})$ wide and $900 \mathrm{ft}(280 \mathrm{~m})$ long. The height of the cell will range from $30 \mathrm{ft}(9 \mathrm{~m})$ to $50 \mathrm{ft}(20 \mathrm{~m})$ above the existing ground surface. The disposal cell footprint will be excavated to prepare for emplacement of the contaminated materials. Some of the excavated materials will be used as fill along the embankment sides and for the upper portion of the cover. The remaining excavated material will be left on the site.

All contaminated materials will be covered with a $2-\mathrm{ft}(0.6-\mathrm{m})$ thick layer of finegrained materials that will constitute a radon barrier to prevent release of radon into the atmosphere. A $2-\mathrm{ft}(0.6-\mathrm{m})$ thick frost protection layer of fine-grained material will be placed over the radon barrier, and then a 6 -in $(0.2-\mathrm{m})$ sand and gravel bedding layer. The top of the cover will consist of riprap ranging in depth from 8 to 12 in $(0.2$ to $0.30 \mathrm{~m})$. The disposal cell will have a 2- to 4 -percent topslope and 25-percent sideslopes. The completed disposal cell will occupy an area of 12 ac $(4.9 \mathrm{ha})$. A buffer area of $31 \mathrm{ac}(13 \mathrm{ha})$ will bring the total final disposal site to 43 ac (17 ha).

The remedial action is expected to take 19 months. During the summer of the first year, the sites will be prepared, the existing dirt road upgraded, the disposal cell excavated, existing foundations demolished, and contaminated materials from the UC and NC sites excavated and placed. A 3- to 5-month winter shutdown will be scheduled. The second-summer activities will include collecting cover materials from the Dolores River and Disappointment Valley borrow sites and constructing the cover system. Final site grading and site restoration will also be performed.

Detailed drawings of the disposal cell facility are shown in Attachment 1 , Drawing Nos. SRK-0-10-0330 through SRK-DS-10-0338.

After the contaminated materials are removed, the processing sites will be restored with uncontaminated fill and revegetated or mulched. After remedial action, the processing site eventually will be released for use consistent with existing land use controls.

\subsection{SCOPE AND CONTENT}

This RAS report has been structured to provide a brief but comprehensive description of the remedial action proposed for the Slick Rock sites. Data and supporting information generated for this remedial action are too extensive to be incorporated into this single document, although pertinent information and data are included, as are references to supporting documents. The RAP consists of 
this RAS and the following attached reports, which describe various aspects of the remedial action in more detail:

- Attachment 1, Specifications, Design Drawings, Inforrnation for Reviewers, Information for Bidders (four volumes), Calculations (four volumes), Reports (one volume), and Cost Estimates (one voluma).

- Attachment 2, Geology Report.

- Attachment 3, Ground Water Hydrology Report.

- Attachment 4, Water Resources Protection Strategy.

\subsection{REMEDIAL ACTION SELECTION ORGANIZATION}

Sections 2.0 through 6.0 are organized by technical discipline. The approach adopted in the RAS report is similar to that adopted by the NRC for site technical evaluation reports (TER). This RAS report is formatted in accordance with the requirements of NRC standard format and content (SF\&C) guide (NRC, 1989) for remedial action selection for Uranium Mill Tailings Remedial Action (UMTRA) Project sites. The RAS report has been compiled to facilitate NRC preparation of its TERs. The RAS report does not contain design details. These are available in supporting documents, reports, drawings, specifications, and calculations (see Attachment 1).

Table 1.2 summarizes the relationship between design details and criteria and supporting calculations and reports.

\subsection{COLLATERAL DOCUMENTS}

The Environmental Assessment of Remedial Action at the Slick Rock Sites (DOE, 1993a) describes existing conditions at the sites, the proposed remedial actions and alternatives, and the environmental impacts of the proposed action. It also includes environmental details not reported in this RAP.

An additional supporting document is the Technical Approach Document (TAD) (DOE, 1989), which describes technical approaches and procedures used on the UMTRA Project. The TAD also discusses major technical areas, design considerations, surface water hydrology and erosion control, geotechnical aspects of pile design, radiological issues (the design of the radon barrier, in particular), and protection of ground water resources.

Copies of these documents, as well as supporting data and calculations, are on file in the UMTRA Project Office, Albuquerque, New Mexico. 


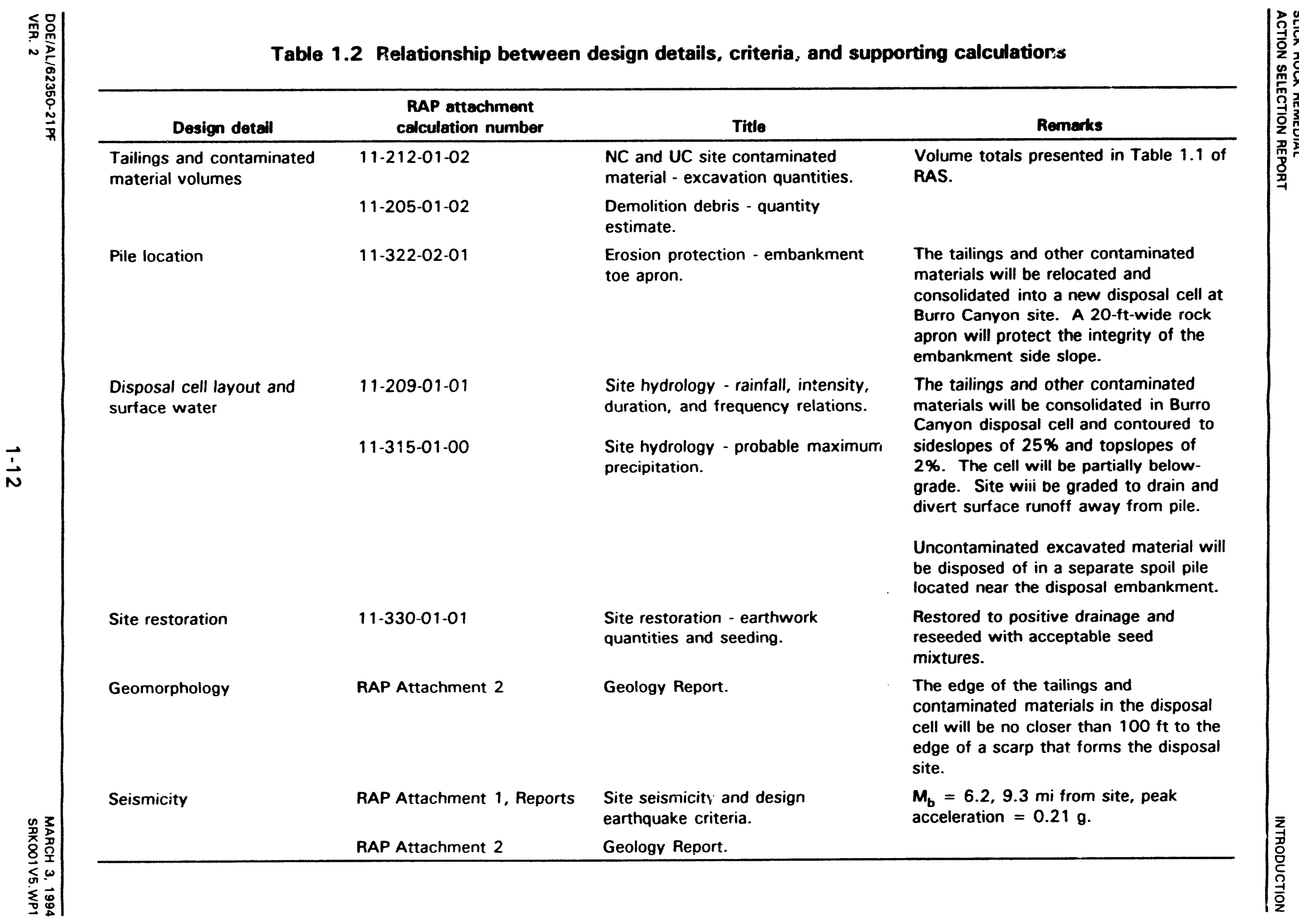




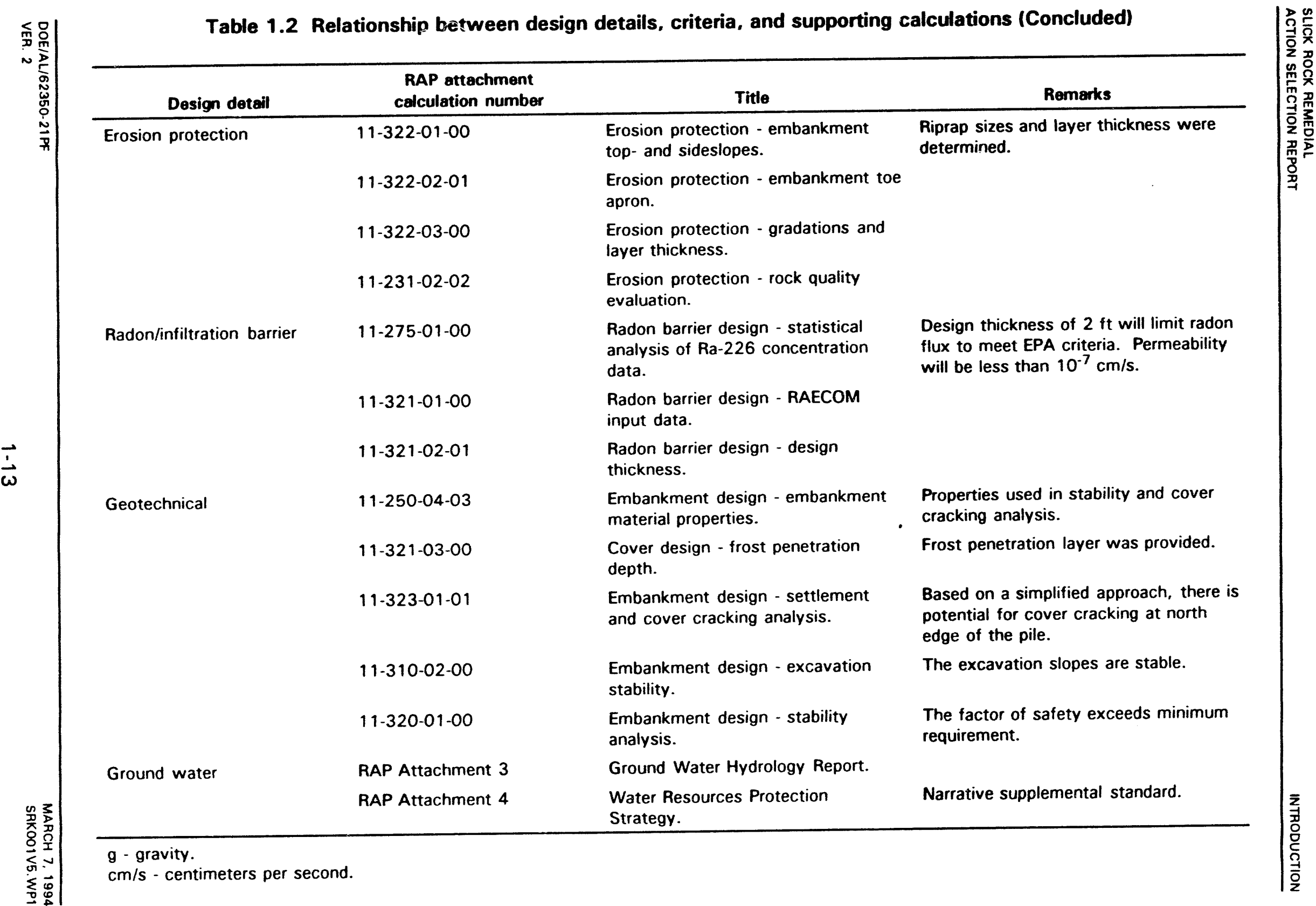




\subsection{GEOLOGY}

This section documents that, at the Burro Canyon site, the DOE has adequately characterized the impact of geologic conditions on the long-term performance objectives of remedial action as defined by 40 CFR $\$ 192.02$ (1993).

The EPA standards listed in 40 CFR Part 192 do not include generic or site-specific requirements for characterization of the geological conditions at UMTRA Project sites. Rather, 40 CFR Part 192 requires that controls must be effective for 1000 years to the extent achievable, and in any case for at least 200 years. To achieve this long-term stability, certain geologic performance objectives must be met. For example, the NRC standard review plan (SRP) (NRC, 1985) requires information about basic regional and site geology and site stratigraphy. This information is the basis of the geotechnical and ground water aspects of disposal cell performance evaluation, described in Sections 3.0 and 5.0 of this document. An evaluation of the potential geomorphic hazards is required, and the DOE should show that potential geomorphic change will not affect the site or the disposal cell integrity throughout its design life. The site geological characterization should estimate earthquake-induced ground accelerations that could occur at the site, as well as the potential for other types of tectonic hazards that could affect the performance of the disposal cell. Geological site characterization must also demonstrate that future resource development will not adversely affect the disposal cell's stability during the design life. Additional criteria that support an evaluation of the adequacy of the site, regional geology, and the basis of the work described herein are in the DOE TAD (DOE, 1989).

\subsection{SCOPE OF WORK}

Detailed investigations of geologic, geomorphic, and seismic conditions at the site were conducted by the Tech.ical Assistance Contractor (TAC). Geologic investigations were carried out in accordance with the procedures and approaches described in the TAD (DOE, 1989) to gather the data specified in the NRC SRP and SF\&C guide. These investigations included the compilation and analysis of previously published and unpublished geological literature and data; review and analysis of historical and instrumental seismic data; geological field mapping and observations; refraction seismic surveys; review of site-specific subsurface geological and geotechnical data, including borehole logs and samples from boreholes, test pits, and trenches; aerial reconnaissance and analysis of stereo-pair aerial photographs; geologic interpretation of existing LANDSAT satellite imagery; and studies of previous work. Details of the data gathering and interpretation procedures are provided in the documents referenced in this section.

\subsection{REGIONAL GEOLOGY}

As noted in the NRC SRP, regional geology must be defined in sufficient detail to provide a clear perspective and orientation to site-specific subsurface information. 
The DOE has characterized the regional geologic conditions in the site geology report (Attachment 2). Information in this RAS report was derived from published studies referenced in Attachment 2. The site region is defined as the area within a $65-\mathrm{km}$ radius of the disposal site.

\subsubsection{Regional physiography}

As required in the NRC SF\&C guide, the following main physiographic features of the region will be characterized:

- Type of geomorphic surface that surrounds the site.

- General relief and topography of the region.

- Regional drainage systems.

- Major regional geomorphic processes.

The Burro Canyon site is in the northeastern part of the Colorado Plateau physiographic province near its boundary with the southern Rocky Mountain province. This portion of the Colorado Plateau is characterized ty large-scale folds, unwarped plateaus, and deep, narrow river canyons. The entrenched meanders of the Dolores River and the folded belt of the Paradox Basin are the principal features of the region.

Further details of the regional physiographic setting and the basis for the above description are contained in Section 2.1 of Attachment 2. That section describes the geomorphic landforms, the relief and topography of the region, the drainage systems, and the types and rates of the major geomorphic processes.

\subsubsection{Stratigraphic setting}

Bedrock in the site region includes exposures of complete stratigraphic sequences of Mesozoic deposits. Most upper Cretaceous and all Tertiary deposits have been removed by erosion. Paleozoic rocks underlie the reyion but are rarely exposed.

Further details of the technical approach to and the results of the characterization of the regional and site stratigraphy are in Section 2.2 of Attachment 2. Figures 2.3, 3.1, and 3.2 of Attachment 2 show the bedrock within the site region and site area. Table 2.1 of Attachment 2 describes the stratigraphic units. This document further details the age, name, thickness, lithology, induration, relation to adjacent units, and geographic distribution.

\subsubsection{Siructural setting}

The site is located in the Colorado Plateau structural province, an intercontinental subplate with a thicker crust than adjoining provinces. Substructures within the plateau consist of broad basins containing thick Tertiary deposits and uplift structures with exposures of Precambrian basement rock. 
Details of the site structural setting are described in Section 2.3 of Attachment 2. The regional structural elements (Figures 2.4 and 2.5 of Attachment 2) show the relationship of the site region to adjoining structural provinces.

The bedrock structure of the disposal site foundation is described in Section 3.1 of Attachment 2 and is illustrated on the geology map in Figure 3.1 of Attachment 2.

\subsubsection{Seismotectonics}

The DOE has characterized the potential for tectonic activity in local and regional structures that may contribute to earthquake generation and may affect the suitability of the site and design as follows.

\section{Seismicity}

The seismotectonic characteristics of the Colorado Plateau and adjacent provinces are given in Table 2.2 of Attachment 2. The maximum earthquake (ME) of the source area and the resultant acceleration at the site are shown in Table 2.5 of Attachment 2.

The historical seismicity of the region of all earthquakes of magnitude 4.0 or greater within a $65-\mathrm{km}$ radius of the site is presented in Table 2.4 of Attachment 2. This historical record is derived from the seismic data for a radius of $125 \mathrm{mi}(201 \mathrm{~km})$ from the site including the date, location coordinates, depth of focus, intensity, and magnitude. The original 1985 earthquake data file for this site has been updated by reference to the 1989 data file of the nearby Dry Flats site near Naturita, Colorado (NGDC, 1989). Because the largest earthquake predicted or experienced within the western United States is a magnitude 8.2 event, the accepted attenuation/distance relationship for this event at a distance of $65-\mathrm{km}$ is not expected to result in a peak horizontal acceleration (PHA) at the site that would exceed the PHA for a 6.2 magnitude event as a floating earthquake (FE) located $9.3 \mathrm{mi}(15 \mathrm{~km})$ away. The $65-\mathrm{km}$ site radius is therefore considered appropriate for design purposes.

The seismic record is discussed in detail in Section 2.4 of Attachment 2. It describes seismic activity that is related to remote seismic source zones. A brief summary of the main points follows.

Seismicity for the site region, based upon credible locations of historical earthquakes and instrumentally located epicenters, has occurred mostly in the border zones of the Colorado Plateau and in the intermountain seismic zone. The largest events recorded within the Colorado Plateau are in the range of 5.3 to 5.7 magnitude. The largest earthquake within a $125-\mathrm{mi}(201-\mathrm{km})$ radius was of 5.5 magnitude located $130 \mathrm{mi}(210 \mathrm{~km})$ southeast of the site in the Rio Grande Rift area near the New Mexico-Colorado state line. Only one 
macroseismic earthquake occurred within the site region, with a magnitude 4.0 event in 1970 at a distance of $33 \mathrm{mi}(53 \mathrm{~km})$.

The following information is the basis of the parameters used in designing the disposal cell to ensure stability against earthquake-induced instability (see Section 4.2 of Attachment 2).

\section{Tectonics}

Section 2.4 of Attachment 2 details the seismotectonic setting related to the structural geology of the region. The tectonic provinces are defined in Figure 2.4 of Attachment 2. These provinces are based on previously referenced studies of the region that present the correlation of structural features with seismic activity. Evidence of tectonic activity with the Colorado Plateau province and adjacent provinces (such as uplift or subsidence rates, evidence of active fault traces, and volcanism) are cited as characteristics of each province. Plate 2.1 of Attachment 2 shows the epicentral locations within a $65-\mathrm{km}$ site radius relative to the known fault systems within the site region. Important aspects of the regional tectonics are summarized below.

The interior portion of the Colorado Plateau province in which the disposal site is located is considered stable, with a more active border zone on its east, west, and south sides. Neogene faulting is rare within the interior. An exception is the Uncompahgre Uplift structure, where minor earthquakes have been associated with faults on its northeastern side and its southeastern terminus with the western mountains. These faults are located beyond the site region.

This information on the site region tectonics is the basis of the estimation of site-specific seismic design parameters.

\subsubsection{Resource development}

To ensure that future resource development will not jeopardize the remedial action, the occurrence of recoverable resources in the site area must be characterized. Resources of concern are those which, if exploited, could result in inadvertent intrusion into the disposal site.

Economic resources in the site region consist essentially of uranium and vanadium ore located within the Salt Wash Member of the Morrison Formation. The nearest mine is approximately $0.5 \mathrm{mi}(0.8 \mathrm{~km})$ southwest of the site in the Slick Rock uranium mining district.

The DOE has identified the resources occurring nearest the site, such as uranium ore and gas and oil deposits. Suspected uranium and vanadium ore zones 1 or $2 \mathrm{ft}(0.3$ to $0.6 \mathrm{~m})$ thick occur at depths of $900 \mathrm{ft}(300 \mathrm{~m})$ below the site. These ore deposits are not considered economically important resources at the present time because of the depressed uranium market. Based on the calculation for the impact of mining at that depth (presented in the 
appendix to Attachment 2), future resource development will not affect or be affected by the proposed remedial action.

Further details of the resources of the site and region are presented in Section 2.5 of Attachment 2. The locations of mineral resources are shown in Figures 2.9 and 2.10 of Attachment 2.

\section{SITE GEOLOGY}

Bedrock geological conditions at the site are characterized primarily to provide the basic information required for site geotechnical stability evaluations and ground water performance assessments. Surficial geologic conditions are characterized to establish the geomorphic history and processes at the site, and hence to determine that long-term stability standards will be met.

The procedures used to characterize site geology and the details of that site characterization are contained in Section 3.0 of Attachment 2. Figures 3.1 through 3.7 of Attachment 2 characterize the site geology and geomorphology through topographic base maps and cross sections. Salient site geologic features are described below.

\subsubsection{Bedrock geology}

The bedrock that underlies the site consists of shales and thin sandstones of the lower unit of the Dakota Sandstone Formation, which is underlain by the mudstone/claystone of the Burro Canyon Formation. The most significant strata in terms of hydrogeology are an upper sandstone at a depth of about $80 \mathrm{ft}$ $(20 \mathrm{~m})$, a middle sandstone at a depth of about $170 \mathrm{ft}(52 \mathrm{~m})$, and a lower sandstone at a depth of about $300 \mathrm{ft}(90 \mathrm{~m})$. The cell will be founded in the mudstone, siltstone, and claystone strata of the Burro Canyon Formation.

\subsubsection{Surficial geology}

Surficial deposits on the approximately 18-ac (7.3-ha) mesa surface consist of thin soil covering the interior drainage basin of the site. Thickness ranges from less than $1 \mathrm{ft}(0.3 \mathrm{~m})$ at the perimeter to $4 \mathrm{ft}(1 \mathrm{~m})$ along the interior drainage swale. Because most of the surface area will be utilized in the cell design, the soil will be stripped to bedrock and stockpiled for other use. The surficial soils on and around the site are shown in Figure 3.7 of Attachment 2 and are discussed in Section 3.2 of Attachment 2. The DOE concludes that the surficial deposits will not detrimentally affect the long-term stability of the disposal cell.

\subsubsection{Geomorphology}

Site geomorphology is characterized to confirm the stability of the current landscape and to provide reasonable assurance that stability will be maintained for the performance period required by the standards. The DOE has 
characterized the regional and site geomorphology by referring to published literature, topographic maps, site inspections, and the procedures described in the TAD. Details of the regional geomorphology are provided in Section 2.1 of Attachment 2. Site-specific geomorphology is described in detail in Section $\mathbf{3 . 3}$ of Attachment 2. The main aspects of the geomorphology directly relevant to site remedial action are summarized below.

The site lies on a small mesa protected by outcrops of the resistant sandstone strata in the lower Dakota Sandstone Formation. The rim of the mesa forms the drainage divide so that no off-site overland flow can occur. Drainage on the mesa is interior with only a single outlet founded on sandstone that occurs at the south rim. The principal geomorphic process at the site is scarp retreat and head cutting. All tributary drainage around the mesa terminates on the exposed rock rim of the mesa. Natural armoring of the mesa slopes has developed from the detritus of the sandstone ledges.

The DOE has examined the geomorphic processes that could affect site stability and has described the geomorphic processes that created the landforms and the geomorphic processes that are likely to take place in the future (see Sections 2.1 and 3.3 of Attachment 2). This characterization is considered sufficient to assess the geomorphic stability of the site, as described in Section 2.4.1 of this report (where the DOE confirms that there is a reasonable assurance that stability will be maintained for the performance period of the design standards).

\subsection{GEOLOGIC STABILITY}

This section describes the local geologic and seismic conditions likely to affect the geotechnical stability of the disposal cell and the long-term stability of the landscape environment. It also analyzes the characteristics of unconsolidated deposits and geomorphic processes at the site that may affect long-term stability. In general, this section characterizes the suitability of the site geology including lithology, stratigraphy, and structural conditions as a foundation for the disposal cell.

\subsubsection{Geomorphic stability}

The DOE provides evidence of the long-term stability of the site in Section 3.0 and describes the stability that is expected for the performance period of the proposed remedial action in Section 4.0 of Attachment 2. The main aspects of the geomorphic stability of the site are discussed below.

The site has experienced long-term geomorphic stability. The topography indicates that stable conditions are likely to continue for the performance period of the remedial action. The evidence for geomorphic stability is shown by the resistance of the cap rock sandstone to development of gullies on the mesa sideslopes and in the exit drainage of the mesa top. 
To enhance geomorphic stability, a minimum setback of $100 \mathrm{ft}(30 \mathrm{~m})$ from the edge of the mesa escarpment is recommended for the contaminated materials. Where the integrity of the mesa rim is encroached, the sideslopes will require placement of erosion protection rock. The central drainage exit at the south side of the mesa, if overlapped by the cell, will require erosion protection against headward advance of this tributary.

The age of the geomorphic surfaces has been established in the preceding sections by reference to the rate of the scarp retreat. The geomorphic processes that could influence the disposal cell and remedial action have been identified and quantified by the DOE. Specific projections relating to recommendations and engineering designs for site stability are presented regarding the potential for scarp retreat and headward advance of the tributaries. On the basis of these evaluations, the DOE concludes that the site is geomorphically stable and will continue to be for the performance period of the disposal cell.

\subsubsection{Seismotectonic stability}

The DOE has determined that the disposal site and designs will provide long-term stability during seismic events by developing an understanding of the anticipated ground motion at the site as a result of these everits. Having catalogued the seismic activity, identified the significant geologic structures, and delineated the tectonic provinces, the DOE provides an analysis of the seismic sources that would most affect the stability of the site in Section 2.4 of Attachment 2. Each potentially active fault and the remote seismotectonic sources are shown in Tables 4.1 and 4.2 of Attachment 2 and discussed in the text, with the calculated ME and the estimated ME of previous studies. Using appropriate attenuation relationships for the site region, the PHA for these sources and a FE is also presented. Only one fault system has been identified as having a critical potential acceleration relative to the $\mathrm{FE}$ as a design event. This fault system is determined to be noncapable so that the FE is determined to be the design earthquake.

The design earthquake for this site was determined to be an $M_{L}=6.2$ event occurring at a distance of $9.3 \mathrm{mi}(15 \mathrm{~km})$ from the site as an FE. The PHA of bedrock at the site is estimated to be 0.21 gravity $(\mathrm{g})$. Details of the studies leading to this conclusion are given in Section 4.2 of Attachment 2.

Specific seismic parameters to be used for the design are presented in the following design criteria section. These criteria were used in conjunction with appropriate soil strength parameters, pile geometry, and ground water information to assess slope stability. The geotechnical engineering aspects of the remedial action at the Slick Rock, Colorado, sites are presented in Section 3.0 of this document and in applicable calculation sets of Attachment 1.

Seismic design parameters were derived using procedures that are presented in Section 1.2 of Attachment 2. These procedures are set forth in the TAD 
(DOE, 1989). The acceleration attenuation relationship of Campbell (1981) was used to derive the on-site peak horizontal acceleration.

\section{Desian criteria}

- Long-term slope stability seismic coefficient: $K=0.14$ (0.66 of PHA).

- Short-term slope stability seismic coefficient: $K=0.11$ (0.5 of PHA).

- Liquefaction analysis: ground surface horizontal acceleration $a_{\max }=0.21 \mathrm{~g}$.

Potential geologic conditions, including seismic shaking, liquefaction, on-site rupture, ground collapse, and volcanism, are ruled out as potential disturbing forces on the disposal cell, either because they will not occur or because the geotechnical design of the cell is formulated to resist such forces.

\subsection{GEOLOGIC SUITABILITY}

On the basis of the site characterization described in this section and supporting documents, the details of the final RAP, and the provisions for stability included in the design of the disposal cell, the DOE concludes that there is reasonable assurance that regional and site geologic conditions have been characterized adequately to meet the requirements of 40 CFR Part 192. Conditions potentially affecting long-term stability have been identified and either avoided by design layout or mitigated by the details of the remedial action design. 


\subsection{GEOTECHNICAL ENGINEERING}

\subsection{INTRODUCTION}

This section and supporting references describe the geotechnical engineering aspects of the remedial action at the Slick Rock, Colorado, sites. The following aspects of the remedial action are described: geotechnical information related to the processing, borrow, and disposal sites; design details related to the disposal site and the disposal cell and its cover; and materials associated with the remedial action, including the foundation and excavation materials, tailings, and other contaminated materials. Related geologic aspects, such as site geology, geomorphology, and geomorphic and seismic characterization, are presented in Section 2.0. Surface water and erosion control are described in Section 4.0. Ground water conditions at the sites are described in Section 5.0.

\subsection{SITE AND MATERIAL CHARACTERIZATION}

\subsubsection{Geotechnical investigation}

Geotechnical investigations and site characterization programs were performed at both processing sites and at the disposal and borrow sites. The data obtained during these site characterization programs are presented in Attachment 1, Information for Bidders, Volumes I, II, III, and IV (January 1994). The geotechnical investigations included excavating test pits and augering boreholes. See Attachment 1, Drawing Nos. SRK-GE-10-0304 and SRK-PS-100318 , SRK-PS-10-0325, and SRK-DS-10-0338, for the locations of test pits and boreholes. Test pit and borehole logs are compiled and included in Attachment 1, Information for Bidders, Volumes III and IV; and Appendix B of Attachment 3.

\section{Processing sites}

Tailings materials at the Slick Rock processing sites are located at the UC tailings pile and the NC tailings pile. Two site characterization programs were conducted at the processing sites. The pre-1987 program conducted by the TAC included 3 test pits at the NC pile and 19 test pits excavated at the UC pile. The DOE conducted additional subsurface investigations at the UC pile by augering 51 boreholes and performing 12 piezocone soundings. Another 26 boreholes were advanced at the NC site. Bulk samples were taken for laboratory analyses that required larger amounts of material.

Additional data were collected at the Slick Rock processing sites during investigations performed in 1987 and 1989. The TAC drilled another 13 boreholes at the UC site in 1989. The Remedial Action Contractor (RAC) also collected and analyzed soil samples from an additional 20 boreholes and 21 test pits at the UC site and 2 boreholes and 12 test pits at the NC site. All 
applicable logs from the processing site can be found in Attachment 1, Information for Bidders, Volume III; and Appendix B of Attachment 3.

\section{Disposal site}

The DOE performed the disposal area subsurface investigations, obtaining geotechnical data from 20 test pits excavated with a backhoe. The test pits were advanced to depths of 3 to $10 \mathrm{ft}(1$ to $3 \mathrm{~m})$. Additional geotechnical data were obtained during 1990 and 1993. Sixteen well boreholes and six coreholes were advanced during 1990. The coreholes were drilled to depths ranging from 80 to $430 \mathrm{ft}(20$ to $130 \mathrm{~m})$. Seven coreholes and seven test pits were advanced during November 1993. The coreholes were drilled to depths up to $37 \mathrm{ft}(11 \mathrm{~m})$, and the test pits were advanced to depths of $10 \mathrm{ft}(3 \mathrm{~m})$.

Disturbed and undisturbed samples were obtained from the boreholes using standard sampling and penetration techniques. Only disturbed samples of material were obtained from test pits. Test pit and borehole logs are compiled and presented in Attachment 1, Information for Bidders, Volume III; and Appendix B of Attachment 3.

\section{Borrow areas}

The DOE conducted numerous investigations of borrow areas. A total of 27 test pits ( 9 by the TAC and 18 by the RAC) were excavated and logged to characterize the soil at the Disappointment Valley borrow site. Soil from the Disappointment Valley borrow site will be used to construct the radon barrier. All test pits were excavated using a backhoe. Bulk samples were collected for laboratory determination of moisture content and the geotechnical characteristics of remolded samples. Samples of the erosion protection rock, ranging from gravel to cobble-sized material, were obtained from 23 test pits excavated in the Dolores River borrow sites located between the UC and NC piles. Two of the 23 test pits are located at the Troy Rose gravel pit. An additional rock borrow source is located about $0.2 \mathrm{mi}(0.4 \mathrm{~km})$ south of the UC mill site on the western bank of the Dolores River. Rock samples from this site were obtained from three deep test pits and three boreholes. Test pit logs are compiled and presented in Attachment 1, Information for Bidders, Volume IV; and Appendix B of Attachment 3.

\subsubsection{Testing program}

The materials at the Slick Rock processing sites were classified and tested. The testing program included sieve analysis (gradation), Atterberg limits, specific gravity, moisture density determinations, compaction and consolidation tests, determination of saturated hydraulic conductivity, percolation and water pressure tests, capillary moisture analysis, direct shear tests, and triaxial shear strength tests. The results of the individual tests are presented in Attachment 1, Information for Bidders, Volume IV. Summary tables and 
selected geotechnical design parameters are found in Attachment 1, Volume I, Calculation No. SRK-250-04-03.

\section{Disposal site foundation and borrow materials}

The DOE conducted the geotechnical engineering testing program for the Burro Canyon disposal site, Disappointment Valley radon barrier borrow site, and Dolores River rock borrow sites. The test program for characterizing the disposal site foundation soils included performing field moisture and density tests in five test pits using the sand-cone method. Soil from depths of 3 to $10 \mathrm{ft}(1$ to $3 \mathrm{~m}$ ) below the surface were tested. Additional data on the disposal site foundation were obtained from laboratory testing of borehole samples taken from depth ranging from 20 to $90 \mathrm{ft}(6$ to $30 \mathrm{~m})$ below the ground surface. The Disappointment Valley borrow site test program included soil classification and material properties testing. Testing included gradation. Atterberg limits, consolidation tests, saturated hydraulic conductivity, organic content, capillary moisture, triaxial shear strength, and moisture-density relationships. Rock durability tests and petrographic analyses were performed on rock from the Dolores River borrow sites. The durability tests performed were the Los Angeles abrasion, sulfate soundness, sodium adsorption and specific gravity, and Brazilian tensile strength tests. Petrographic analyses were performed as described by the American Society for Testing and Materials (ASTM) (ASTM, 1991). The results of the individual tests are contained in Attachment 1, Information for Bidders, Volumes III and IV.

\section{Conclusion}

All laboratory and field testing procedures followed the standards published by the ASTM or the U.S. Army Corps of Engineers, Engineering Manual EM 1110-2-1906 (USACE, 1970a). The testing program employed a sufficient number of samples and tests to define all critical soil parameters appropriate for support of the engineering analyses. In addition, the scope of the testing program and the use of resulting data to define material properties are in general conformance with the applicable provisions of the NRC SRP (NRC, 1985). Quality assurance (QA) and quality control $(\mathrm{QC})$ activities followed appropriate UMTRA Project procedures.

\subsubsection{Ground water conditions}

\section{Processing sites and rock borrow sites}

Three ground water systems are present in the vicinity of the UC and NC sites and the proposed rock borrow sites: 1) the unconfined Dolores River alluvium, 2) the semiconfined to confined Entrada Formation, and 3) the unconfined to confined Navajo Sandstone. These three hydrostratigraphic units may be interconnected in the vicinity of the processing sites. Additional information is provided in Section $\mathbf{5 . 1}$ of this document. 


\section{Disposal site}

Four hydrostratigraphic units consisting of one unsaturated unit and three saturated units underlie the proposed disposal site. The unsaturated hydrostratigraphic unit is the lowest unit of the Dakota Sandstone and the uppermost Burro Canyon Formation claystones and mudstones. The three saturated sandstone units are within the Burro Canyon Formation at approximate depths of 100,200 , and $300 \mathrm{ft}(30,60$, and $90 \mathrm{~m})$ and are described as the upper, middle, and lower sandstone units, respectively. The upper sandstone unit of the Burro Canyon Formation is the uppermost aquifer underlying the disposal cell footprint. This unit is characterized by low yield and limited use. Ground water movement in the upper sandstone unit is semiconfined. Ground water in lithologic units underlying the upper sandstone unit is protected from potential site-related contamination by 1$)$ hydrogeologic isolation provided by the low permeability mudstone units that inhibit the downward migration of water, and 2) upward vertical hydraulic gradients in the confined lower and middle sandstone units of the Burro Canyon Formation.

\subsubsection{Site stratiaraphy}

\section{Processing sites}

The UC site lies on a bench of Entrada Formation Sandstone with a thin, probably discontinuous Quaternary terrace gravel cover and overlaps the bedrock bench toward the river onto a thicker, younger gravel deposit. The NC site lies partially on sandstone and mudstone of the Salt Wash Member of the Morrison Formation and partially on Quaternary terrace gravels.

At Slick Rock, the slimes were removed for processing at Rifle, Colorado, leaving only sand tailings. Tailings in the UC pile generally contain less than 15 percent fines, while samples of NC tailings contain generally less than 5 percent fines.

\section{Disposal site}

The soil at the Burro Canyon disposal site consists of reddish-brown, sandy clay to clayey sand with thicknesses ranging from 0 to $1.5 \mathrm{ft}(0.46 \mathrm{~m})$ at the perimeter of the mesa top to 0.25 to $4.5 \mathrm{ft}(0.08$ to $1.4 \mathrm{~m})$ in the middle of the site. In most places, the soil is directly underlain by a thin sandstone stratum. In a few locations, the soil covers a dark-gray, carbonaceous shale/claystone. The upper unit of the Burro Canyon Formation forms the foundation at the site. A more detailed discussion of the stratigraphy and geology of the disposal site is presented in Section 2.0 and Attachment 2.

\section{Borrow sites}

The Disappointment Valley radon barrier borrow site is overlain by approximately $1 \mathrm{ft}(0.3 \mathrm{~m})$ of a brown, silty clay topsoil. Underlying this surface layer, a 
silty-clayey sand layer ranging from 0.7 to $10 \mathrm{ft}(0.2$ to $3 \mathrm{~m})$ in thickness was encountered. A medium plastic Mancos Shale layer lies beneath the clayey sand layer. The clayey sand and weathered sections of the Mancos Shale are suitable for radon barrier material.

The proposed borrow sites for riprap and gravel are adjacent to the Dolores River. The stratigraphy of the sites is generally sand overlying a moderately thick river terrace deposit. The terrace deposits contain subrounded, gravel-size particles and subrounded cobbles ranging in size from 6 to 8 in (approximately $0.2 \mathrm{~m}$ ) in diameter. Based on the site characterization data and flood and floodplain analyses, the terrace deposits should contain a sufficient quantity of large diameter rock to construct the erosion protection features of the Burro Canyon disposal cell.

\subsubsection{Introduction}

This section and the supporting documents referenced in Table 1.2 present the engineering evaluation of the information and analyses that were undertaken to demonstrate that the proposed remedial action design will meet the EPA standards for long-term stability, including slope stability, settlement, liquefaction, and cover cracking. The analyses were performed for design-basis events such as the design earthquake, the design flood, and extreme meteorological conditions.

\subsubsection{Slope stability}

The geotechnical stability of the disposal embankment slopes was evaluated. The most critical slope sections were analyzed for both the short-term. end-of-construction state and the long-term state. Excavation slopes were evaluated to ensure stability during construction. A brief description follows of the work that supports these conclusions.

\section{Disposal cell slopes}

A plan of the pile layout and the location of the most critical sections are presented in Attachment 1, Calculation 11-310-01-00. Soil parameters for the compacted tailings and radon barrier were established by appropriate testing of representative material. Values of soil parameters for the select fill, riprap, and foundation materials were assigned, based on published data and data obtained from the geotechnical explorations at the site. Soil parameters used for the evaluation are presented in Attachment 1, Calculation 11-250-04-03.

The Modified Janbu Method and infinite slope methods were employed to assess the conditions to which the critical slope might be subjected. Results are shown in Table 3.1. Factors of safety against failure were analyzed for both static and seismic loading conditions. The seismic stability of the slope was 
investigated by the pseudostatic method of analysis using horizontal seismic coefficients of 0.11 for the short-term case and 0.14 for the long-term case. Pseudostatic methods are considered acceptable because of the conservatism employed in determining soil parameters and seismic coefficient values. Minimum requirements for the static loading conditions and seismic loading conditions are specified in the TAD (DOE, 1989).

Table 3.1 Results of slope stability analysis"

\begin{tabular}{llcc}
\hline \multicolumn{1}{c}{ Case } & \multicolumn{1}{c}{$\begin{array}{c}\text { Loading } \\
\text { condition }\end{array}$} & $\begin{array}{c}\text { Short-term } \\
\text { conditions } \\
\text { (EOC) }\end{array}$ & $\begin{array}{c}\text { Long-term } \\
\text { conditions } \\
\text { (LT) }\end{array}$ \\
\hline Excavation slope & Static & 1.3 & 1.5 \\
Embankment slope & Static & 3.03 & 3.00 \\
& Seismic & 2.02 & 1.84 \\
Infinite slope (shallow plane) & Static & 2.67 & 6.32 \\
& Seismic & 1.85 & 4.00 \\
\hline
\end{tabular}

'As specified by the TAD (DOE, 1989).

NA - not applicable.

EOC - end of construction.

\section{Excavation slopes}

The excavation slopes will be 1 horizontal to 1 vertical $(1: 1)$ along the disposal cell perimeter. Soil parameters for the disposal area foundation material were assigned on the basis of data obtained from geotechnical explorations and published data; they are presented in Attachment 1, Calculation 11-250-04-03. A minimum factor of safety against failure of 1.3 was determined for the temporary (during construction) excavation slope, and a safety factor of 1.5 was calculated for the permanent (post-construction) slope. The analysis of the excavation slope stability is presented in Attachment 1, Calculation $11-310-02-00$.

\section{Conclusion}

The methods of analysis employed are considered to be conservative approaches and satisfy the requirements in the TAD. In addition, the most critical conditions to which the slopes might be subjected have been considered and the characteristics of all slopes have been well defined. From the results of the slope stability evaluation, it can be concluded that the embankment slopes would be stable under short-term and long-term conditions, and thus would comply with the EPA standard 40 CFR \$192.02(a) for long-term stability. 


\subsubsection{Settlement}

As a result of volume changes in the tailings and foundation materials, differential settlement of the disposal cell was evaluated to determine the potential for disruptive conditions such as surface water flow concentration, ponding, or cracking of the radon barrier cover. The locations evaluated were chosen to determine the range of total and differential settlements across the cell. A detailed analysis of settlement is presented in Attachment 1, Calculation 11-323-01-01.

Soil parameters for the radon barrier and compacted tailings were determined from appropriate testing of representative material. The other materials, including the select fill and foundation, were assigned soil parameter values on the basis of data obtained from geotechnical investigations and published data.

Multilayered analyses using conventional consolidation theory were used to evaluate the amount of primary and secondary settlement and the time rates of primary settlement that will occur at locations on both sides of this interface. Comparison was made of the secondary consolidation at different locations to determine long-term differential settlement gradients across the interface. Based on the results of this analysis (see Attachment 1, Calculation 11-323-01-01), the cover will not experience significant cracking, nor will water collect on the top of the embankment.

\subsubsection{Liquefaction potential}

For liquefaction to occur, a soil must be saturated, loose, and cohesionless. Both the compacted tailings and foundation material satisfy the cohesionless criterion, but because of an infiltration-inhibiting radon/infiltration barrier and a depth of 80 to $150 \mathrm{ft}(20$ to $50 \mathrm{~m})$ to ground water, the tailings and foundation material will not become saturated. In addition, neither the compacted tailings nor the medium dense-to-dense foundation material can be considered loose. Therefore, the stabilized tailings embankment is not susceptible to liquefaction.

\subsubsection{Cover design}

Figure 1.6 shows a cross section of the cover system. A more detailed layout of the cover system is shown in Attachment 1, Drawings SRK DS-10-0335 and SRK-DS-10-0336. The design for the disposal embankment cover consists of the following layers, descending from the top: an 8-in $(0.2-\mathrm{m})$ thick layer of ripra, ; a 6-in $(0.2-\mathrm{m})$ thick sand/gravel layer; a $2.0-\mathrm{ft}(0.61-\mathrm{m})$ thick frost protection layer; and a $2.0-\mathrm{ft}(0.61-\mathrm{m})$ thick radon barrier. The only difference between the top and sideslope covers is that the riprap layer on the sideslope will be 1.0-ft $(0.30-\mathrm{m})$ thick. Cover component material types and functions are listed in Table 3.2. 
Table 3.2 Cover components and their function

\begin{tabular}{|c|c|c|}
\hline Cover component & Material type & Function \\
\hline Erosion protection layer & Riprap & $\begin{array}{l}\text { Prevents erosion of the disposal cell by } \\
\text { surface water runoff. }\end{array}$ \\
\hline \multirow[t]{3}{*}{ Bedding layer } & Sand/gravel & $\begin{array}{l}\text { Prevents displacement of large- } \\
\text { diameter rock. }\end{array}$ \\
\hline & & $\begin{array}{l}\text { Protects frost protection layer (fine- } \\
\text { grained material) from erosion. }\end{array}$ \\
\hline & & Drains water laterally. \\
\hline Frost protection layer & $\begin{array}{l}\text { Fine-g, ained soil } \\
\text { with some sand }\end{array}$ & $\begin{array}{l}\text { Protects the radon/infiltration barrier } \\
\text { from the effects of frost. }\end{array}$ \\
\hline \multirow[t]{2}{*}{ Radon barrier } & Sandy clay & Inhibits radon emanation. \\
\hline & & $\begin{array}{l}\text { Inhibits infiltration through the } \\
\text { underlying contaminated material. }\end{array}$ \\
\hline
\end{tabular}

\section{Conclusion}

The material properties and available quantities for the cover materials have been adequately defined in a manner that conforms with the applicable provisions of the SRP. In addition, the performance of the cover system has been evaluated using both state-of-the-art techniques and standard engineering methods; the result is that the cover will remain effective for a period of time that is in compliance with the EPA standard 40 CFR $\$ 192.02$ for long-term performance.

\subsubsection{Subsidence}

Because mining may take place beneath the Burro Canyon site in the future, the potential exists for subsidence of the foundation soil of the disposal cell footprint. The potential effect of subsidence on the stability of the disposal cell was assessed in the appendix to Attachment 2, TAC Calculation SRK-04-90-0303-00. Based on previous mining practices in the area and conservative assumptions for analysis, future uranium and vanadium mining of the Upper Salt Wash Formation will not adversely affect the long-term stability of the disposal cell at Burro Canyon. The top of the Upper Salt Wash Formation is approximately $900 \mathrm{ft}(300 \mathrm{~m})$ below the surface of the proposed Burro Canyon disposal site. 


\subsection{CONSTRUCTION DETAILS}

\subsubsection{Construction methods and features}

Detailed descriptions of the remedial action are provided in Attachment 1 , including site plans and engineering drawings that convey the remedial action design features and construction specifications that provide a detailed explanation of the proposed construction methods. In addition, Attachment 1, Calculations, Volumes I through VI, contains calculations that support the remedial action design features and volumes of materials.

Remedial action will meet the following general construction requirements:

- The maximum percentage of organics contained within the reshaped disposal cell should not exceed 5 percent by volume, and the material should be distributed so as to avoid pockets or layers of organic matter.

- All uncontaminated vegetation and organic material in areas subject to excavation and placement should be removed and disposed of off the site.

- Contaminated demolition debris should be reduced to manageable pieces and carefully placed in the embankment to ensure that no voids or nesting exist around the debris and that the adjacent contaminated materials are compacted to 90 percent of the Standard Proctor density (ASTM D698) (ASTM, 1991).

- Excavation of all contaminated materials should be monitored carefully to prevent the inclusion of unnecessary, uncontaminated material in the pile.

- The surfaces of all areas where fill materials will be placed should be proof-rolled before placement of contaminated materials. Soft zones should be excavated and replaced with compacted material.

- The relocated tailings and contaminated materials should be compacted to at least 90 percent of the Standard Proctor density (ASTM D698) (ASTM, 1991) and should be moisture-conditioned or dried to specified moisture content to achieve specified density.

- Design criteria for the radon barrier cover include 1) placement at a minimum of 95 percent of the Standard Proctor density (ASTM D698) (ASTM, 1991), 2) placement at or near the optimum moisture content, and 3) compaction by a kneading method.

\subsubsection{Testing and inspection}

Attachment 1, Subcontract Documents, details the methods, procedures, and frequencies by which construction materials and activities will be tested and inspected to verify compliance with the design specifications. 
Quality will be controlled in accordance with the UMTRA QA plan (DOE, 1993b). The DOE and the TAC will conduct QA audits and an in-process surveillance to verify and ensure that remedial action activities are performed in accordance with approved UMTRA Project requirements.

\subsubsection{Construction activities and construction sequence}

\section{General}

Construction activities will take place at the following locations: the existing tailings sites (UC and NC sites); areas contaminated by windblown and waterborne tailings; the Burro Canyon disposal site; and borrow sites.

During remedial action construction, all contaminated runoff will be contained. Contaminated disturbed areas at the UC site will be graded so that runoff flows to a retention basin. Construction at the NC site will occur over a short period and during the dry early summer months; therefore, a wastewater retention basin will not be required. Uncontaminated disturbed areas will be graded to divert runoff from contaminated areas.

Ditches at the UC site and the Burro Canyon disposal site will be sized to carry the peak runoff flows from a 10-year storm event and will serve to divert uncontaminated runoff away from the sites and to divert contaminated runoff at the UC site to the retention basin for temporary storage or treatment and discharge.

The retention basin will receive water from contaminated areas and decontamination activities, including equipment and truck washdowns. The retention basins at the processing site and the disposal site are designed to retain the runoff from a 10-year, 24-hour storm in conjunction with the volume in the basin due to the average monthly runoff, as well as wastewater generated from the remedial action activities and all sediment inflow during the remedial action.

The emergency spillway from the basin is designed to discharge the 25-year, 6-hour storm runoff while $1 \mathrm{ft}(0.3 \mathrm{~m})$ of freeboard is maintained between the top of the embankment and the water surface. Normally, a wastewater discharge will not be necessary during the construction period. However, if an event greater than the 10-year storm occurs, wastewater may have to be discharged from the retention pond. The characteristics of any wastewater or storm water to be discharged from the pond will be specified in applicable federal and state permits.

\section{Wastewater treatment}

Wastewater will be directed to the retention basin to provide primary settling as well as flow and contaminant equalization. Water in the retention basin may be treated further if a discharge is required. Also, water collected in the retention 
basin will be used only for dust control within contaminated areas and for compaction of contaminated material.

\section{Equipment decontamination pad}

To prevent contaminated materials from being carried out of the construction areas, decontamination pads with a holding pond and a pump will be provided at the UC and NC sites and the Burro Canyon disposal site to wash contaminated equipment, as required.

\section{Dust control}

Dust generated by excavating, earth moving, vehicle use, temporary material stockpiling, and other activities will be controlled and minimized by the use of water and water-based surfactants. Only uncontaminated water will be used to control dust in uncontaminated areas.

Water recycled from the wastewater retention ponds will be used to suppress dust created by stockpiling and working with contaminated materials.

\section{Construction sequence}

The following construction sequence is proposed for the remedial action. The final schedule will contain more details and the construction subcontractor will be allowed flexibility in the final construction sequence. Activities are presented in the order in which they should occur, although some events will be concurrent.

1. Erect site perimeter fences and remove existing fences.

2. Perform clearing and grubbing at the UC, NC, and Burro Canyon sites.

3. Start excavating the Burro Canyon disposal cell foundation.

4. Construct, upgrade, and maintain access roads to the NC and Burro Canyon sites, including excavations at the junction of the Burro Canyon site access road and State Highway 141.

5. Excavate and stockpile contaminated materials from access control and decontamination pad areas in the UC and NC sites.

6. Construct access control areas and decontamination pads at the UC, NC, and Burro Canyon sites.

7. Construct the temporary bypass road at the UC site.

8. At the UC and Burro Canyon sites, construct retention basins and temporary drainage ditches. Stockpile contaminated materials excavated at 
the UC site during this process for later disposal in the tailings embankment; stockpile excavated uncontaminated materials for later use as fill. Perform grading required for site drainage. At the NC and Burro Canyon sites, construct silt fences.

9. Demolish abandoned structures and utilities encountered and stockpile the debris of the UC site for haul to the Burro Canyon site.

10. Clean up windblown/waterborne contamination at the UC site, including the small area west of the bridge and the gas line right-of-way. Stockpile material within the fenced area or haul to the Burro Canyon site.

11. Open the borrow sites.

12. Complete preparation of the tailings embankment foundation.

13. Excavate and transport the NC contaminated materials, including demolition debris, to the Burro Canyon embankment.

14. Demolish the temporary facilities at the NC site and perform final site grading of the NC area.

15. Excavate and transport the UC contaminated materials to the tailings embankment.

16. Seal existing monitor wells.

17. Demolish decontamination and wash facilities, including the decontamination pad sump, and dispose of the debris in the tailings embankment.

18. Dispose of contaminated sediments from the temporary drainage ditches and the washwater retention basins of the UC and Burro Canyon areas in the tailings embankment, as required, and dispose of the synthetic membrane liner.

19. Construct the $2.0-\mathrm{ft}(0.61-\mathrm{m})$ thick radon barrier cover over the contaminated material in the tailings embankment.

20. Construct the $2.0-\mathrm{ft}(0.61-\mathrm{m})$ thick frost protection layer over the radon barrier.

21. Place erosion protection materials over the frost protection barrier. The erosion protection materials shall consist of a 6 -in $(0.2-\mathrm{m})$ thick layer of bedding material topped by a layer of rock riprap.

22. Remove and dispose of the subcontractor's stockpiled material, close the borrow areas, and remove the site perimeter fencing. 
23. Grade and restore the Burro Canyon and UC sites and borrow areas to provide drainage, including placement of uncontaminated fill, conditioning, and revegetation.

\section{Schedule}

Remedial action is scheduled to begin March 15,1995 . Winter shutdown periods may be up to 5 months. The construction schedule may be refined during the final design process.

\subsection{SUMMARY}

Geotechnical engineering and construction evaluations were conducted using common engineering practices and commonly accepted techniques. These evaluations extended to levels of detail that are in general conformance with applicable provisions of the NRC SRP for UMTRA Project Title I mill tailings RAPS. Evaluation of the previous results show that the proposed remedial action design will comply with the EPA standard 40 CFR Part 192, Subpart A, for geotechnical engineering and construction. 


\subsection{SURFACE WATER HYDROLOGY AND EROSION PROTECTION}

\subsection{HYDROLOGIC DESCRIPTION AND REMEDIAL ACTION DESIGN}

The elevations of the Burro Canyon disposal site range from 5870 to $5912 \mathrm{ft}$ (1790 to $1802 \mathrm{~m}$ ) above MSL. The disposal site is located on a small mesa that is completely isolated from runoff from upland drainages. The drainage north and east of the site is the Nicholas Wash Basin. The disposal site and basins south of the site drain into Joe Davis Canyon. Runoff in the two shallow drainages located in the center of the site (mesa) drains by sheet flow until it reaches the south edge of the mesa; there the flow concentrates into a welldefined gully that incises the rim. Flooding is not considered a hazard at the Burro Canyon disposal site because of its distance from and elevation above the closest stream channel. The drainage characteristics of the Burro Canyon disposal site are illustrated in Figure 4.1.

The erosion protection riprap on the topslopes and sideslopes of the disposal cell will be sized to withstand an on-cell probable maximum precipitation (PMP) storm runoff. The cell also will be protected by a $20-\mathrm{ft}(6-\mathrm{m})$ wide, $5-\mathrm{ft}(2-\mathrm{m})$ deep apron along the toe of the sideslopes. The areas surrounding the disposal cell will be backfilled as required, graded to control surface drainage, and seeded.

\subsection{FLOODING DETERMINATIONS}

To determine the impact of flooding to the sites, the DOE calculated peak flows and velocities and evaluated the need for erosion protection features. All erosion protection features must withstand extreme meteorologic events such as the PMP.

\subsubsection{Probable maximum precipitation}

The determination of the site design PMP is presented in Attachment 1 , Calculation No. 11-315-01-00. A local thunderstorm PMP of approximately 8.1 in $(210 \mathrm{~mm})$ in 1 hour is calculated for a small upland watershed (i.e., the disposal site). The PMP rainfall estimate was developed using Hydrometeorological Report No. 49 (NOAA, 1977).

\subsubsection{Infiltration losses}

In computing the peak flow rate for the design of the rock erosion protection for the disposal cell top, sideslopes, and toe apron, the DOE assumed no infiltration would occur. This estimate is conservative with respect to erosion protection design (see Attachment 1, Calculations 11-322-01-00 and 11-322-02-01). 


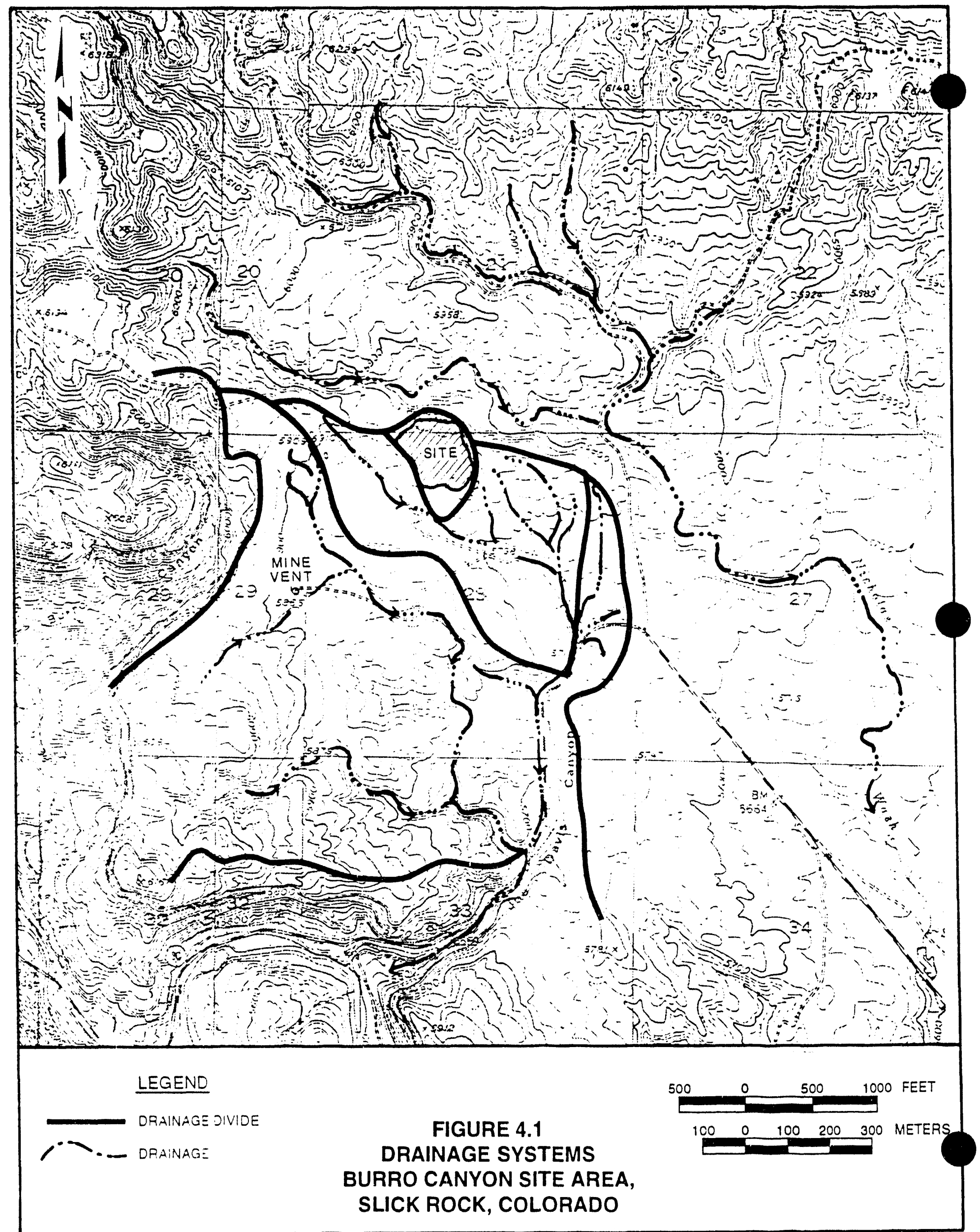




\subsubsection{Time of concentration}

The time of concentration $\left(T_{c}\right)$ is the time for runoff to reach the outlet of a drainage basin from the most remote point in the basin. For a given volume of runoff, the peak runoff for a given drainage basin (area) is inversely proportional to the $T_{c}$ for that basin. If the $T_{c}$ is conservatively computed to be small, the peak discharge will be conservatively large.

The $T_{c}$ for the topslopes and sideslopes was determined by dividing the slope lengths by the estimated flow velocities. The flow velocities were determined using the Manning Equation. For the design rock size and a critical path length of $130 \mathrm{ft}(40 \mathrm{~m})$, the $T_{c}$ for the topslope is 2.0 minutes; however, a minimum $T_{c}$ of 2.5 minutes is used in all applicable calculations. The $T_{c}$ for the sideslope is 3.2 minutes for a critical path length of $340 \mathrm{ft}(104 \mathrm{~m})$. The $T_{c}$ 's are included in Attachment 1, Calculations SRK-322-01-00 and SRK-322-02-01.

\subsubsection{Rainfall distributions - probable maximum precipitation}

The DOE derived PMP rainfall depths and intensities from Hydrometeorological Report No. 49 (NOAA, 1977). The temporal distribution of the PMP depths and intensities was performed in accordance with the procedure described in the TAD (DOE, 1989).

\subsubsection{Computation of probable maximum flood}

\section{Adiacent waterways}

The disposal site is located on a small mesa, and flooding of adjacent waterways will not impinge on the disposal cell. In addition, no upland drainages contribute runoff toward the site.

\section{On-site drainage}

The Rational Formula and PMP rainfall intensity were used to determine the peak flow rates. Peak unit flow at the end of the topslope is 0.158 cubic feet per second per $\mathrm{ft}\left(\mathrm{ft}^{3} / \mathrm{s} / \mathrm{ft}\right)\left(0.0147\right.$ cubic meters per second per meter $\left.\left[\mathrm{m}^{3} / \mathrm{s} / \mathrm{m}\right]\right)$. Peak unit flow for the sideslope and the toe apron is $0.39 \mathrm{ft}^{3} / \mathrm{s} / \mathrm{ft}$ (Attachment 1, Calculations 11-322-01-00 and 11-322-02-01).

\subsection{FLOW DEPTH AND VELOCITIES}

\subsubsection{Adiacent waterways}

Because the disposal cell is located on a small mesa that is much higher than the surrounding terrain, flooding in adjacent waterways will not impinge on the site. Therefore, analyses of adjacent waterways were not necessary. 


\subsubsection{Drainage ditches}

Because of the disposal cell's location, no permanent drainage or interceptor ditches are required at the Burro Canyon disposal site. A naturally formed swale at the southern end of the mesa will be filled and graded (10 percent) to facilitate drainage from the top and sideslopes of the disposal cell.

\subsubsection{Top and sides of the embankment}

Manning's Equation was used to estimate a flow depth based on the peak sheet flow rate, slope, and an assumed Manning's $n$ value. The appropriateness of the assumed Manning's n was then checked using the U.S. Army Corps of Engineers equation (USACE, 1970b). Based on the calculated $D_{50}$ rock size, the flow depth and velocity at the end of the topslope (for the maximum topslope of 2 percent) will be approximately $0.10 \mathrm{ft}(30 \mathrm{~mm})$ and $1.51 \mathrm{ft} / \mathrm{s}(0.46 \mathrm{~m} / \mathrm{s})$, respectively. For the $4: 1$ sideslopes, the calculated flow depth and velocity are $0.11 \mathrm{ft}(33 \mathrm{~mm})$ and $3.6 \mathrm{ft} / \mathrm{s}(1.16 \mathrm{~m} / \mathrm{s})$, respectively (see Attachment 1 , Calculation 11-322-01-00).

The slope of the toe transitions from 25 percent on the sideslopes to a 2-percent apron slope. Based on the design $D_{50}$ rock size, the flow depth and mean flow velocity over the toe apron will be $0.12 \mathrm{ft}(0.037 \mathrm{~mm})$ and $3.17 \mathrm{ft} / \mathrm{s}$ $(0.97 \mathrm{~m} / \mathrm{s}$ ), respectively (see Attachment 1, Calculation 11-322-02-00).

\subsection{EROSION PROTECTION}

\subsubsection{Topslopes}

The surface layer of riprap on the topslope, which is designed to protect the disposal cell from wind and water erosion, has been sized to withstand the erosive velocities resulting from an on-pile PMP. The DOE proposes to use an 8 -in $(200-\mathrm{mm})$ thick layer of rock with a required $D_{50}$ of 1.7 in $(43 \mathrm{~mm})$. The riprap will be placed on a 6 -in $(200-\mathrm{mm})$ thick bedding layer. The safety factor method was used to determine the appropriate rock size for the topslope. A detailed discussion of rock sizing, including gradation information, is presented in Attachment 1, Calculations 11-322-01-00 and 11-322-03-00.

\subsubsection{Sideslopes}

The rock layer on the sideslopes, which also protects the disposal cell from wind and water erosion, is designed to withstand an occurrence of the local on-pile PMP. The DOE proposes to use a $1-\mathrm{ft}(0.3-\mathrm{m})$ thick layer of rock with a required $D_{50}$ of approximately 4.0 in $(100 \mathrm{~mm})$. The $D_{50}$ rock size where the sideslope transitions to the toe apron will be 5.8 in $(150 \mathrm{~mm})$. The rock layer will be placed on a $0.5-\mathrm{ft}(0.2-\mathrm{m})$ thick bedding layer. Stephenson's Method was used to determine the required rock sizes. The gradation and required thickness of cover layers are presented in Attachment 1, Calculation 11-322-01-00. 


\subsubsection{Toe and sides of the embankment}

At the toe of the disposal cell, the DOE is placing a $20-\mathrm{ft}(6-\mathrm{m})$ wide, $5-\mathrm{ft}(2-\mathrm{m})$ deep layer of rock, with a minimum $D_{50}$ rock size of 5.8 in $(0.15 \mathrm{~m})$. Rock in the toe apron will be placed on a $1-\mathrm{ft}(0.3-\mathrm{m})$ thick sand/gravel bedding layer (see Attachment 1, 11-322-02-01). Several methods were used to estimate the rock size required for the toe apron, including the safety factors method (Stevens et al., 1976), the U.S. Army Corps of Engineers Stilling Basin Method (USACE, 1965), and the Stephenson Method (Stephenson, 1979). The toe apron is designed to protect against local scour due to runoff from a PMP event. Erosion protection requirements are presented in Table 4.1.

Table 4.1 Rock size requirements and layer thickness for the Burro Canyon disposal cell

\begin{tabular}{|c|c|c|c|c|c|}
\hline \multirow[b]{2}{*}{ Location and grade } & \multicolumn{3}{|c|}{ Rock size requirements } & \multicolumn{2}{|c|}{ Layer thickness } \\
\hline & Rock size & (in) & $(\mathrm{mm})$ & (in) & $(\mathrm{mm})$ \\
\hline Topslopes $(2 \%)$ & $D_{50}$ & 1.7 & 43 & 8 & 200 \\
\hline Sideslopes $^{\circ}(25 \%)$ & $D_{50}$ & 4.0 & 100 & 12 & 300 \\
\hline Toe protection & $D_{50}$ & 5.8 & 150 & 60 & $1.5 \mathrm{~m}$ \\
\hline
\end{tabular}

\subsection{ROCK DURABILITY}

The proposed rock borrow sites are located within $5 \mathrm{mi}(8 \mathrm{~km})$ of the proposed Burro Canyon disposal site. These sources are adjacent to the Dolores River and near the UC and NC sites. The gravel and riprap from the selected borrow sites were tested in accordance with the methods and tests described in NUREG/CR2642 (Lindsey et al., 1982). The average score of the tested material was 77. A total of 14 samples were tested and complete results of the tests are presented in Attachment 1. Calculation 11-231-02-02.

\subsection{QUALITY CONTROL TESTING AND INSPECTION FOR EROSION PROTECTION}

Attachment 1 provides details of testing and inspection procedures.

\subsection{UPSTREAM DAM FAILURES}

McPhee Dam is located approximately $36 \mathrm{mi}(58 \mathrm{~km}$ ) (linear distance) upstream from the Burro Canyon disposal site. Based on a flood and floodplain analysis of the Dolores River that included a dam-break scenario, a local PMP event by itself would cause much higher water levels in the Dolores River near Slick Rock than a catastrophic failure of the McPhee Dam and the subsequent release of impounded water. As the Burro Canyon disposal site is nearly $400 \mathrm{ft}(100 \mathrm{~m})$ higher than the invert elevation of the Dolores River, it will not be affected by the probable maximum flood or a breach of the McPhee Dam. 


\subsection{SUMMARY}

The DOE concludes that the Burro Canyon disposal cell design will meet EPA requirements as stated in 40 CFR Part 192 with regard to flood design measures and erosion protection. An adequate hydraulic design has been provided to reasonably ensure stability of the contaminated material and tailings for a period of up to 1000 years. 


\subsection{WATER RESOURCES PROTECTION}

The DOE must demonstrate compliance with EPA standards for ground water protection at inactive uranium mill tailings sites. These standards are contained in proposed revisions to Subparts A and C of 40 CFR Part 192 (1993) under Title I of the UMTRCA, as amended. Remedial action taken by the DOE must comply with the proposed standards until the EPA promulgates thern in final form (UMTRCA, Section 108) (42 USC $\$ 7901$ et seq.). This section summarizes the water resources protection strategy for the Slick Rock uranium mill tailings Burro Canyon disposal site and demonstrates compliance with the proposed ground water standards. A detailed hydrogeologic characterization of ground water at the UC and NC processing sites and the Burro Canyon disposal site is presented in Attachment 3 . The water resources protection strategy for the Burro Canyon disposal site is presented in Attachment 4.

To achieve compliance with the proposed EPA ground water protection standards (Subpart A of 40 CFR Part 192), the DOE proposes to apply supplemental standards for limited use ground water because of low yield (less than 150 gallons per day [gpd]) $\left(6.6 \times 10^{-3}\right.$ liters per second [L/s]) in the uppermost aquifer.

Ground water in lithologic units underlying the upper sandstone unit of the Burro Canyon Formation (uppermost aquifer) is protected from potential site-related contamination by hydrogeologic isolation. Low permeability mudstone units separate the three (upper, middle, and lower) sandstone units of the Burro Canyon Formation, and upward vertical hydraulic gradients in the lower and middle sandstone units inhibit the downward migration of water. As a result, the proposed remedial action will ensure protection of human health and the environment.

\subsection{HYDROGEOLOGIC CHARACTERIZATION}

The DOE has characterized the hydrogeologic units, aquifer hydraulic and transport properties, tailings materials, geochemical conditions, and water use at the Slick Rock UC and NC processing sites and the Burro Canyon disposal site. Major points are discussed in the following subsections. Attachment 3 describes in detail the hydrologic site characterization efforts.

\subsubsection{Identification of hydrogeologic units}

\section{Processing site}

The uppermost aquifer at the NC and UC sites consists of three hydrostratigraphic units: the Quaternary alluvium associated with the Dolores River floodplain deposits; the Slick Rock and Dewey Bridge Members of the Entrada Formation; and the Navajo Sandstone. A plan map of the NC and UC sites is provided in Figure 5.1. Figure 5.2 provides a stratigraphic cross section transecting both the UC and NC processing sites. Ground water flow is unconfined in the alluvium and is expected to be semiconfined to confined in the underlying Entrada Formation and unconfined to confined in the Navajo 


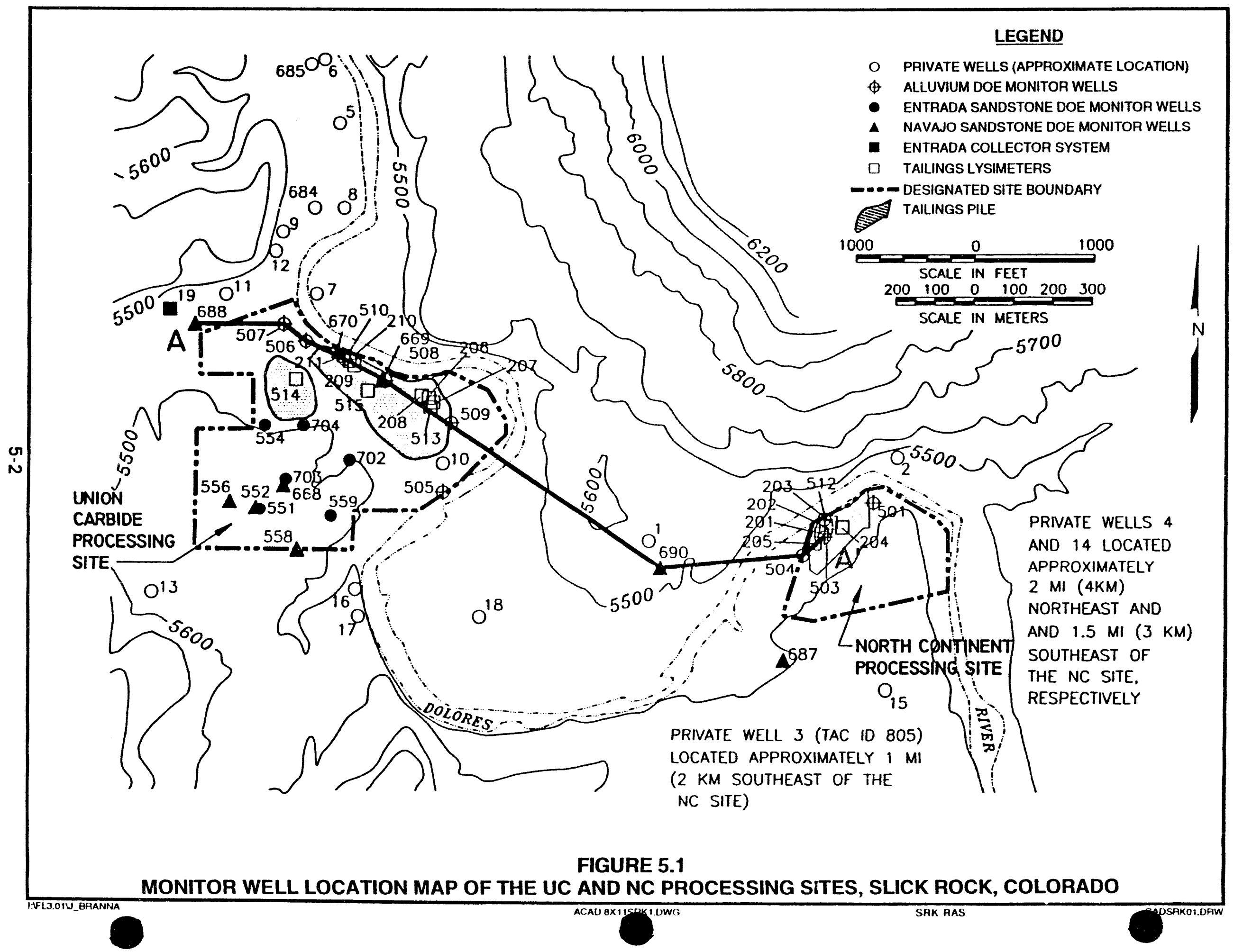




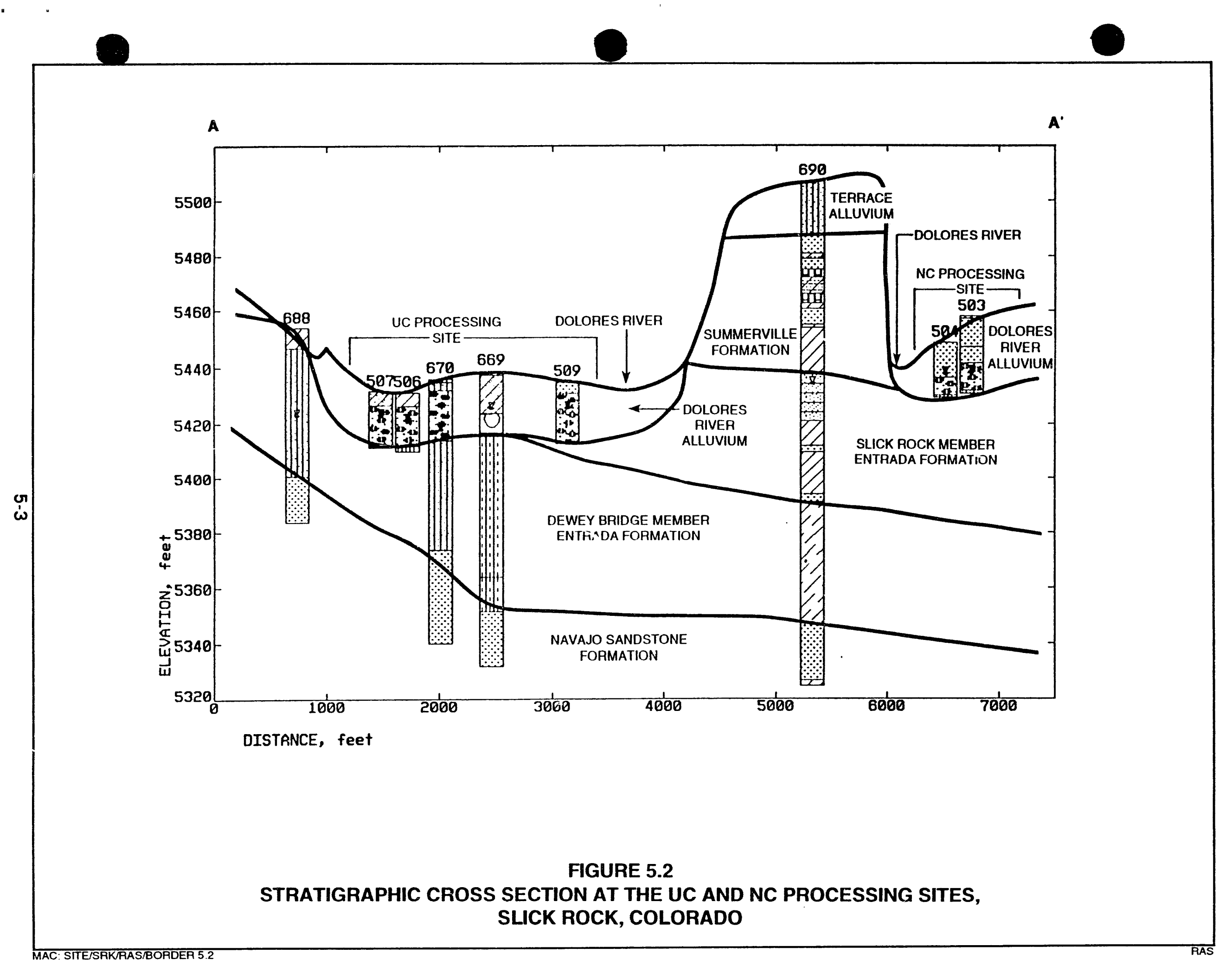


Sandstone Formation. These three formations may be hydraulically connected, based on lithologic data and ground water levels. Ground water elevations in the alluvium, Entrada Formation, and Navajo Sandstone remain relatively constant and do not show seasonal fluctuations.

The Dolores River alluvium is composed of unconsolidated clayey sands, sandy gravels, and cobbles from the ground surface to an approximate depth of $20 \mathrm{ft}$ $(6 \mathrm{~m})$ at both the UC and NC sites. Quaternary alluvium materials also cap the tops of terraces surrounding the Dolores River floodplain. However, the occurrence of ground water in the alluvium at the processing sites is limited to the recent channel and paleochannels of the Dolores River. The depth to ground water at both processing sites ranges from 10 to $20 \mathrm{ft}(3$ to $6 \mathrm{~m})$ in wells screened in the alluvium and is approximately the same as the surface water level of the Dolores River. Ground water flow in the alluvium is generally to the north.

Jurassic Entrada Formation underlies the alluvium in the Dolores River floodplain and underlies the Summerville Formation in terraced areas adjacent to the floodplain. The canyon walls of these terraces consist of sandstones, mudstones, and shales of the Summerville Formation. Two members of the Entrada Formation are present: the Slick Rock Member and the Dewey Bridge Member. The Slick Rock Member is composed of light brown fine-grained sand that is generally not well cemented and therefore erodes easily. The Dewey Bridge Member of the Entrada Formation underlies the Slick Rock Member at the NC processing site and directly underlies Dolores River alluvium at the UC site, where the Slick Rock Member is absent. Consisting of reddish-brown clayey siltstone, very fine-grained sandstone, and shale, the Dewey Bridge Member is more impermeable than the Slick Rock Member. The Dewey Bridge and Slick Rock Members of the Entrada Formaticn were encountered beneath the alluvial deposits to depths ranging from 20 to $160 \mathrm{ft}(6$ to $49 \mathrm{~m})$. Ground water movement appears to be to the east in the Entrada Formation, based on available water level data from monitor wells on the UC site. However, this representation may be biased by a limited number of monitor wells placed across a relatively small areal extent of the UC site.

The Navajo Sandstone Formation underlies the Entrada Formation throughout the Slick Rock area at depths ranging from 53 to $170 \mathrm{ft}(16$ to $52 \mathrm{~m}$ ) below the surface. The Navajo Sandstone is composed of light-brown to reddish-brown, fine-grained sandstone. The direction of ground water flow in the Navajo Sandstone is generally to the north at both processing sites. Variability in the directions of the ground water flow is expected to be primarily a result of differences in subsurface material permeability. The static ground water elevations suggest that ground water in the Navajo Sandstone is unconfined to confined, depending upon the permeability and thickness of the overlying hydrostratigraphic units. Because the bottom of the Navajo Sandstone was not encountered in any of the DOE borings, the thickness of the Navajo Sandstone has not been determined directly in the area of the Slick Rock processing sites. 
However, Shawe et al. (1968) report that the Navajo Sandstone Formation ranges from 0 to $420 \mathrm{ft}(128 \mathrm{~m})$ thick in the Slick Rock district.

\section{Disposal site}

A site plan with hydrogeologic testing locations at the proposed Burro Canyon site is shown in Figure 5.3. Four hydrostratigraphic units, consisting of one unsaturated unit and three saturated units, underlie the proposed disposal site, as shown in the hydrogeologic cross section in Figure 5.4. The unsaturated hydrostratigraphic unit is the lowest unit of the Dakota Sandstone and the uppermost Burro Canyon claystones and mudstones. The three saturated sandstone units within the Burro Canyon Formation are at approximate depths of 100,200 , and $300 \mathrm{ft}(30,60$, and $90 \mathrm{~m})$ and are described as the upper, middle, and lower units, respectively. These units are composed of fine- to medium-grained sandstone layers ranging from 20 to $75 \mathrm{ft}(6$ to $23 \mathrm{~m})$ in thickness. The sandstone layers are hydrogeologically separated from one another by interbedded mudstone and siltstone units approximately 25 to $75 \mathrm{ft}$ $(7.6$ to $23 \mathrm{~m})$ thick.

The lowest unit of Dakota Sandstone consists primarily of low-permeability carbonaceous shale and mudstone. Two thin sandstone layers, approximately 1 to $6 \mathrm{ft}(0.3$ to $2 \mathrm{~m})$ thick, are interbedded with the shales and mudstones in the lower Dakota Sandstone.

Ground water in the upper sandstone unit of the Burro Canyon Formation is semiconfined and the yield is very low. The top of the upper sandstone unit is 77 to $99 \mathrm{ft}(23$ to $30 \mathrm{~m})$ below the surface. The depth to the water table ranges from 75 to $110 \mathrm{ft}(23$ to $34 \mathrm{~m})$. Measured ground water elevations have remained constant over time. The upper sandstone unit is not a current or potential source of drinking water because the quantity of water available is less than $150 \mathrm{gpd}\left(6.6 \times 10^{-3} \mathrm{~L} / \mathrm{s}\right)$, as evidenced by on-site aquifer performance tests. As a result, the ground water in the upper sandstone unit is Class III (limited use) ground water, as defined in 40 CFR $\$ 192.11(\mathrm{e})$ of the EPAproposed ground water standards.

The middle sandstone unit is a confined aquifer approximately $53 \mathrm{ft}(16 \mathrm{~m})$ thick. It is overlain by approximately 60 to $70 \mathrm{ft}$ (about $20 \mathrm{~m}$ ) of laterally extensive mudstone. The top of the middle sandstone unit occurs between 170 and $191 \mathrm{ft}(52$ to $58.2 \mathrm{~m}$ ) below the surface in the vicinity of the disposal cell footprint. The potentiometric surface is approximately $40 \mathrm{ft}(12 \mathrm{~m})$ above the top of the middle sandstone unit, resulting in an upward hydraulic gradient.

The lower sandstone unit of the Rurro Canyon Formation is $39 \mathrm{ft}(12 \mathrm{~m})$ thick beneath the disposal cell, and the top of the unit is approximately $305 \mathrm{ft}$ $(93.0 \mathrm{~m})$ below the surface. Ground water in this unit is confined by the thick sequence of overlying low-permeability mudstones and siltstones of the Burro Canyon Formation and has an upward gradient with the potentiometric surface averaging $52 \mathrm{ft}(16 \mathrm{~m})$ above the middle sandstone unit. 


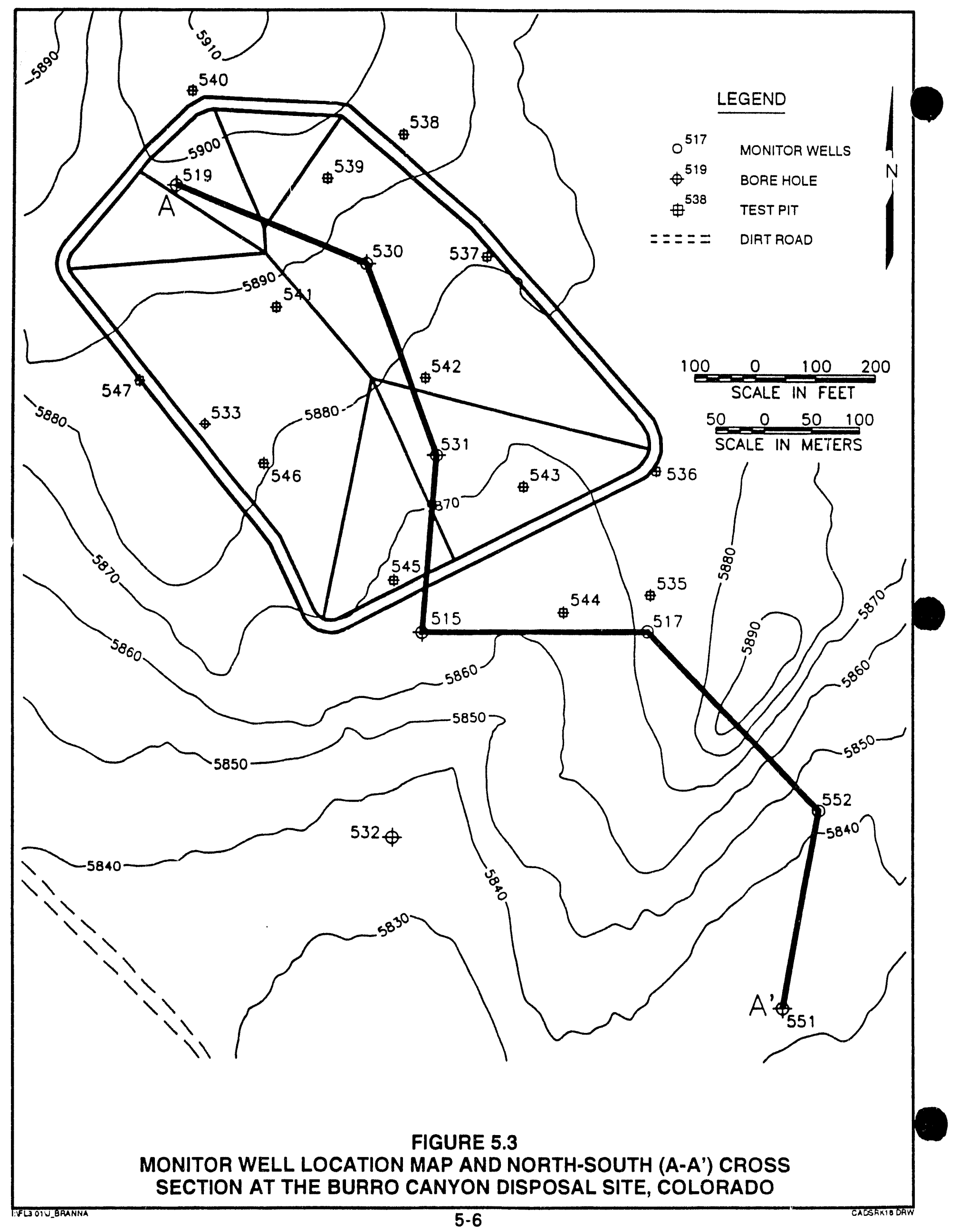




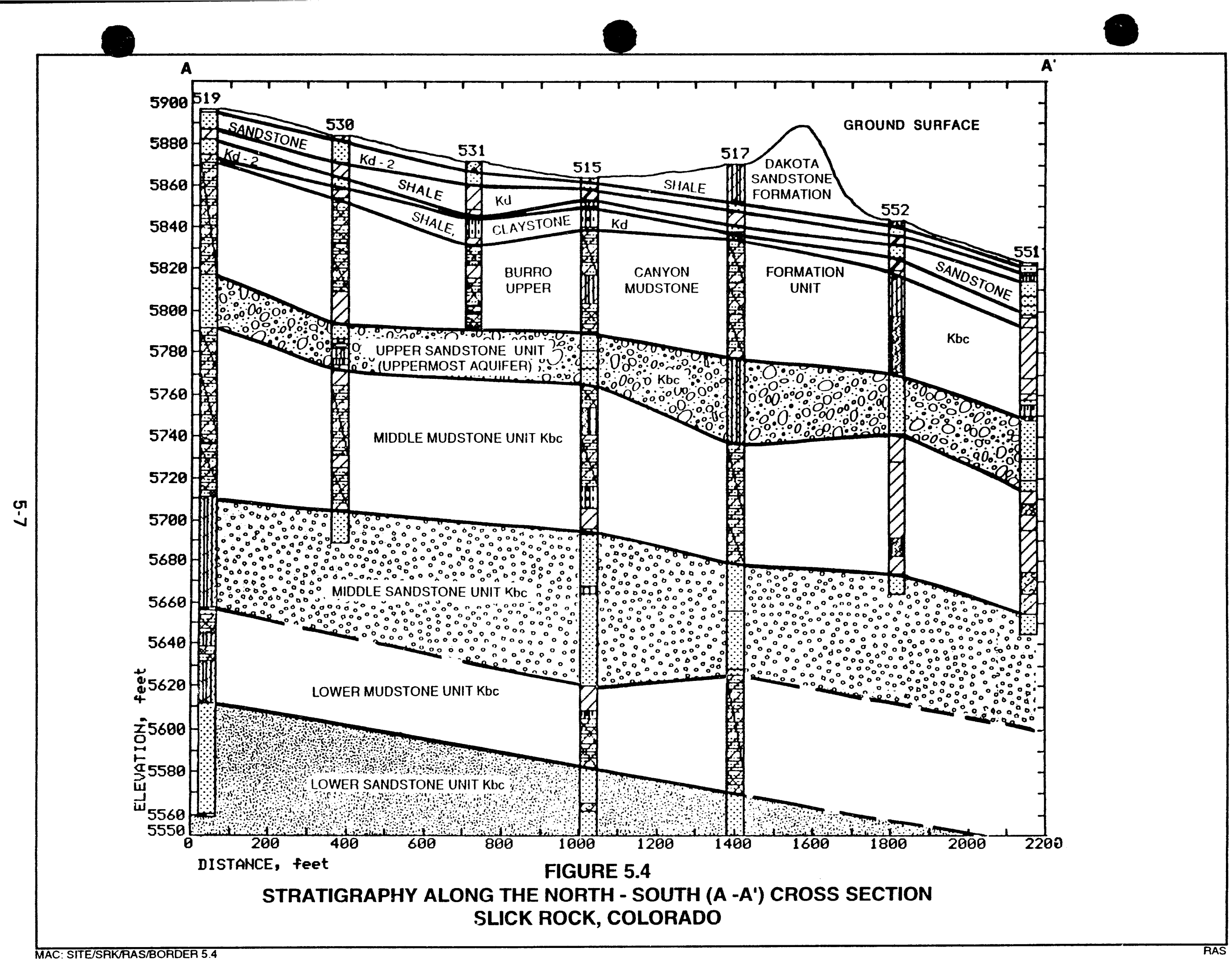


The source of recharge is approximately 0.25 to $0.75 \mathrm{mi}(0.40$ to $1.2 \mathrm{~km})$ northeast of the site. Sandstone beds outcrop along the east limb of the Disappointment syncline and intercept tributaries to the Nicholas Wash drainage system. Ground water then flows to the south-southeast and eventually dissipates (discharges) into the surrounding geologic strata south of the Burro Canyon disposal site.

\subsubsection{Hydraulic and transport properties}

\section{Processing sites}

Slug tests were conducted in the shallow alluvium and in the Navajo Sandstone at the NC and UC processing sites in 1986 and 1987. The middle hydrostratigraphic unit, the Entrada Formation, was not tested. Table 5.1 shows the hydraulic conductivities estimated for the Dolores River alluvium and the Navajo Sandstone at the Slick Rock, Colorado, processing sites.

Table 5.1 Average hydraulic properties at the processing sites

\begin{tabular}{lll}
\hline \multicolumn{1}{c}{ Characteristic } & \multicolumn{1}{c}{ Dolores River alluvium } & \multicolumn{1}{c}{ Navajo Sandstone } \\
\hline $\begin{array}{l}\text { Average hydraulic conductivity } \\
\text { (UC) }\end{array}$ & $14 \mathrm{ft} / \mathrm{day}$ & $2.4 \times 10^{-2} \mathrm{ft} / \mathrm{day}$ \\
& $\left(4.9 \times 10^{-3} \mathrm{~cm} / \mathrm{s}\right)$ & $\left(8.5 \times 10^{-6} \mathrm{~cm} / \mathrm{s}\right)$ \\
$\begin{array}{l}\text { Average hydraulic conductivity } \\
\text { (NC) }\end{array}$ & $\begin{array}{l}23 \mathrm{ft} / \mathrm{day} \\
\left(8.1 \times 10^{-3} \mathrm{~cm} / \mathrm{s}\right)\end{array}$ & Not determined \\
$\begin{array}{l}\text { Average linear ground water } \\
\text { velocity (UC) }\end{array}$ & $150 \mathrm{ft} / \mathrm{yr}$ & $1 \mathrm{ft} / \mathrm{yr}\left(1 \times 10^{-6} \mathrm{~cm} / \mathrm{s}\right)$ \\
$\begin{array}{l}\text { Average linear ground water } \\
\text { velocity (NC) }\end{array}$ & $\left.11.4 \times 10^{-4} \mathrm{~cm} / \mathrm{s}\right)$ & \\
\hline
\end{tabular}

The average linear ground water velocity in the alluvium at the NC site was estimated to be $100 \mathrm{ft}$ per $\mathrm{yr}(\mathrm{ft} / \mathrm{yr})\left(1 \times 10^{-4} \mathrm{~cm} / \mathrm{s}\right)$, based on an average hydraulic conductivity of $23 \mathrm{ft} / \mathrm{day}\left(8.1 \times 10^{-3} \mathrm{~cm} / \mathrm{s}\right)$, a hydraulic gradient of 0.003 , and an effective porosity of 0.25 for sand and gravel (Freeze and Cherry, 1979). The average linear ground water velocity in the alluvium at the UC site is estimated to be $150 \mathrm{ft} / \mathrm{yr}\left(1.4 \times 10^{-4} \mathrm{~cm} / \mathrm{s}\right)$, based on an average hydraulic conductivity of $14 \mathrm{ft} / \mathrm{day}\left(4.9 \times 10^{-3} \mathrm{~cm} / \mathrm{s}\right)$, a hydraulic gradient of 0.008 , and an effective porosity of 0.25 . The Dolores River alluvium is recharged by seepage from the Dolores River upstream of the NC site and by precipitation. Ground water discharges from the alluvium into the Dolores River downgradient of the UC site.

The average linear ground water velocity of the Navajo Sandstone also is considerably lower than that of the alluvium. The calculated average linear ground water velocity in the Navajo Sandstone is $1 \mathrm{ft} / \mathrm{yr}\left(1 \times 10^{-6} \mathrm{~cm} / \mathrm{s}\right)$, based on an average hydraulic conductivity of $2.4 \times 10^{-2} \mathrm{ft} /$ day $\left(8.5 \times 10^{-4} \mathrm{~cm} / \mathrm{s}\right)$ 
under a hydraulic gradient of 0.02 and an estimated effective porosity of 0.30 (Cooley et al., 1969). The Navajo Sandstone is expected to be recharged by seepage from the Dolores River and overlying stratigraphic units. Ground water discharges into surrounding stratigraphic units downgradient of the site.

\section{Disposal site}

Table 5.2 presents average aquifer parameters and average linear ground water velocities for the Dakota Sandstone and the Burro Canyon Formation. The hydraulic conductivities of the unsaturated Dakota Sandstone bedrock and the unsaturated Burro Canyon mudstones were determined by field packer tests. The average horizontal hydraulic conductivity of the lower Dakota Sandstone Formation was $4 \times 10^{-1} \mathrm{ft} / \mathrm{day}\left(1 \times 10^{-4} \mathrm{~cm} / \mathrm{s}\right)$, and the average horizontal hydraulic conductivity of the Burro Canyon mudstones was $6 \times 10^{-3} \mathrm{ft} / \mathrm{day}$ $\left(2 \times 10^{-6} \mathrm{~cm} / \mathrm{s}\right)$. Packer tests indicate that the saturated horizontal hydraulic conductivity of the Dakota Sandstone is moderate and is several orders of magnitude greater than the Burro Canyon mudstone. The hydraulic conductivity decreases with depth in the Burro Canyon mudstone, reflecting decreased fracture permeability with depth.

Table 5.2 Average hydraulic properties at the disposal site

\begin{tabular}{|c|c|c|c|c|c|}
\hline \multirow[b]{2}{*}{ Characteristic } & \multirow{2}{*}{$\begin{array}{c}\text { Dakota } \\
\text { Sandstone }\end{array}$} & \multirow{2}{*}{$\begin{array}{c}\text { Burro Canyon } \\
\text { mudstone }\end{array}$} & \multicolumn{3}{|c|}{ rurro Canyon Formation Sandstone units } \\
\hline & & & Upper & Middle & Lower \\
\hline $\begin{array}{l}\text { Hydraulic } \\
\text { conductivity }\end{array}$ & $\begin{array}{l}4 \times 10^{-1} \mathrm{ft} / \text { day } \\
\left(1 \times 10^{-4} \mathrm{~cm} / \mathrm{s}\right)\end{array}$ & $\begin{array}{l}6 \times 10^{-3} \mathrm{ft} / \text { day } \\
\left(2 \times 10^{-6} \mathrm{~cm} / \mathrm{s}\right)\end{array}$ & $\begin{array}{l}4 \times 10^{-2} \mathrm{ft} / \mathrm{day} \\
\left(1 \times 10^{-5} \mathrm{~cm} / \mathrm{s}\right)\end{array}$ & $\begin{array}{l}9 \times 10^{-2} \mathrm{ft} / \mathrm{day} \\
\left(3 \times 10^{-5} \mathrm{~cm} / \mathrm{s}\right)\end{array}$ & $\begin{array}{l}5 \times 10^{-3} \mathrm{ft} / \mathrm{day} \\
\left(2 \times 10^{-6} \mathrm{~cm} / \mathrm{s}\right)\end{array}$ \\
\hline $\begin{array}{l}\text { Average linear } \\
\text { ground water } \\
\text { velocity }\end{array}$ & NA & NA & $\begin{array}{c}6 \mathrm{ft} / \mathrm{yr} \\
\left(6 \times 10^{-6} \mathrm{~cm} / \mathrm{s}\right)\end{array}$ & $\begin{array}{c}2 \mathrm{ft} / \mathrm{yr} \\
\left(2 \times 10^{-6} \mathrm{~cm} / \mathrm{s}\right)\end{array}$ & $\begin{array}{c}1 \mathrm{ft} / \mathrm{yr} \\
\left(1 \times 10^{-6} \mathrm{~cm} / \mathrm{s}\right)\end{array}$ \\
\hline
\end{tabular}

NA - not applicable.

The average linear ground water velocity in the Burro Canyon upper sandstone unit was estimated to be $6 \mathrm{ft} / \mathrm{yr}\left(6 \times 10^{-6} \mathrm{~cm} / \mathrm{s}\right)$, based on an average hydraulic conductivity of $4 \times 10^{-2} \mathrm{ft} /$ day $\left(1 \times 10^{-5} \mathrm{~cm} / \mathrm{s}\right)$, a hydraulic gradient of 0.038 , and an effective porosity of 0.10 . Ground water flow is to the southeast along the axis of the Disappointment syncline.

The average linear ground water velocity of the Burro Canyon middle sandstone unit is $2 \mathrm{ft} / \mathrm{yr}\left(2 \times 10^{-6} \mathrm{~cm} / \mathrm{s}\right)$, assuming an average hydraulic conductivity of $9 \times 10^{-2} \mathrm{ft} / \mathrm{day}\left(3 \times 10^{-5} \mathrm{~cm} / \mathrm{s}\right)$, a hydraulic gradient of 0.02 , and an effective porosity of 0.2 . The confined conditions in this unit create a substantial upward hydraulic potential. The potentiometric surface of the middie unit averages $42 \mathrm{ft}(13 \mathrm{~m})$ above the top of the sandstone unit. This potentiometric surface, however, is not higher in elevation than the overlying potentiometric surface measured in monitor wells screened in the upper sandstone unit. The direction 
of ground water flow is to the southeast. Recharge to the middle sandstone unit occurs upgradient from the disposal cell, approximately 0.25 to $0.75 \mathrm{mi}$ $(0.40$ to $1.2 \mathrm{~km})$ northeast of the site. Sandstone beds outcrop along the east limb of the Disappointment syncline and intercept tributaries to the Nicholas Wash drainage system. Ground water then flows to the south-southeast and eventually dissipates (discharges) into the surrounding geologic strata south of the Burro Canyon disposal site.

The average linear ground water velocity in the Burro Canyon lower sandstone unit is $1 \mathrm{ft} / \mathrm{yr}\left(1 \times 10^{-6} \mathrm{~cm} / \mathrm{s}\right)$, assuming a hydraulic conductivity of $5 \times$ $10^{-3} \mathrm{ft} /$ day $\left(2 \times 10^{-6} \mathrm{~cm} / \mathrm{s}\right)$, a gradient of 0.06 , and an effective porosity of 0.1 . Ground water in this unit is confined by the thick sequence of overlying lowpermeability mudstones and siltstones of the Burro Canyon Formation. Ground water has an upward gradient with the potentiometric surface 169 to $240 \mathrm{ft}$ $(51.5$ to $73 \mathrm{~m})$ above the top of the lower sandstone unit and averaging $52 \mathrm{ft}$ $(16 \mathrm{~m})$ above the middle sandstone unit. The lower sandstone unit has an extremely low velocity and well yield. Vertical recharge to and discharge from the lower sandstone unit is restricted because the low-permeability interbedded claystone and siltstone strata impede infiltration.

\subsubsection{Geochemical conditions}

\section{Processing site}

Background ground water quality is defined as the quality of ground water expected at the site if uranium processing had not occurred. Background ground water quality is characterized as follows for each of the three hydrostratigraphic units:

Dolores River alluvium. Background ground water quality in the alluvial materials is characterized as a calcium sodium sulfate type at both the NC and UC sites. Total dissolved solids (TDS) concentrations measured in alluvial background monitor wells range from 622 to 1180 milligrams per liter (mg/L). TDS average $802 \mathrm{mg} / \mathrm{L}$ at the NC site and $986 \mathrm{mg} / \mathrm{L}$ at the UC site. The background $\mathrm{pH}$ ranges from 6.9 to 7.7. Concentrations or activities of chromium, molybdenum, uranium, and Ra-226 and -228 exceeded the maximum concentration limits $(\mathrm{MCL})$ in one or more background alluvial monitor wells.

Entrada Formation. Background ground water quality of the Entrada Formation is characterized as a calcium bicarbonate to sodium bicarbonate type. The $\mathrm{pH}$ of ground water in the Entrada is slightly above neutral, ranging from 7.8 to 8.0. TDS concentrations measured in the Entrada background monitor wells range from 147 to $1990 \mathrm{mg} / \mathrm{L}$. Selenium and Ra-226 and -228 exceeded their respective MCLs in ground water samples collected from the background monitor wells screened in the Entrada Formation.

Navajo Sandstone. Background ground water quality in the Navajo Sandstone is characterized as a sodium bicarbonate type at the NC site and a magnesium 
bicarbonate type at the UC site. The $\mathrm{pH}$ of ground water measured in background NC and UC monitor wells screened in the Navajo Sandstone ranges from 7.2 to 7.8. TDS concentrations are generally lower at the UC site (ranging from 229 to $1160 \mathrm{mg} / \mathrm{L}$ ) than at the NC site (ranging from 492 to $1530 \mathrm{mg} / \mathrm{L}$ ). The MCLs for chromium, molybdenum, Ra-226 and -228 , selenium, silver, and uranium were equaled or exceeded on one or more occasions in Navajo Sandstone background monitor well samples.

\section{Tailings}

The NC tailings site consists of the tailings pile and windblown contaminated areas, covering approximately 12 ac $(4.9 \mathrm{ha})$. The tailings primarily consist of sandy gravel, sand, and silty sand. At the UC site, the tailings pile and surrounding contaminated land cover 55 ac (22 ha). The tailings consist of mostly fine- to medium-grained sand with some clayey sand and silt. The tailings material is finer-grained at the UC site than at the NC site. Seepage from the tailings has contaminated the ground water in the alluvium beneath both the NC and UC sites.

The chemical characteristics of the NC and UC tailings materials were evaluated by pore fluid sampling with suction lysimeters. The $\mathrm{pH}$ of the tailings pore fluid is near neutral, ranging from 6.2 to 7.8. The TDS concentrations range from 2430 to $33,900 \mathrm{mg} / \mathrm{L}$. Average concentrations of arsenic, cadmium, molybdenum, selenium, and uranium exceeded the MCLs in lysimeter samples collected from the NC site. At the UC site, the average pore fluid concentrations of cadmium, molybdenum, nitrate, selenium, and uranium exceeded the MCLs.

On-site and downgradient (baseline) water quality has been compared to that of background ground water. Average TDS concentrations in baseline alluvial ground water are approximately 3 times those of background. The primary regulated hazardous constituents of concern in the Dolores River alluvium are molybdenum, nitrate, selenium, and uranium at the UC processing site and selenium and uranium at the NC processing site. The baseline water quality of the Entrada Formation also appears to be affected by uranium processing activities; the average concentrations of TDS in baseline Entrada monitor wells are approximately 3 times those observed in background Entrada monitor wells and concentrations of selenium exceed the $\mathrm{MCL}$ and background. Baseline water quality in the Navajo Sandstone does not appear to be affected by processing activities. TDS, $\mathrm{pH}$, and the regulated constituents show minimal variation between background and baseline water quality.

\section{Disposal site}

Ground water quality data were characterized individually for each sandstone unit in the Burro Canyon Formation because the units are hydrogeologically separated from one another. Ground waters in the upper and middle Burro Canyon sandstone units have been classified as sulfate/sodium bicarbonate. 
Ground water in the lower Burro Canyon Sandstone unit is sodium bicarbonate. Ground water pH is near neutral to slightly above neutral, ranging from 7.5 to 9.1 in the upper sandstone unit, 7.2 to 7.6 in the middle sandstone unit, and 8.6 to 9.6 in the lower sandstone unit. TDS concentrations tend to decrease with depth, ranging from 598 to $945 \mathrm{mg} / \mathrm{L}$ in the upper sandstone unit, 460 to $658 \mathrm{mg} / \mathrm{L}$ in the middle sandstone unit, and 281 to $336 \mathrm{mg} / \mathrm{L}$ in the lower sandstone unit.

Naturally occurring selenium and Ra-226 and -228 have equaled or exceeded the proposed EPA MCLs in monitor wells screened in the upper sandstone unit. In addition, the EPA MCL for Ra-226 and -228 was slightly exceeded in one monitor well screened in the middle sandstone unit, in a one-time occurrence.

\subsubsection{Characterization methods}

The DOE characterized the hydrogeologic setting of the processing and disposal sites by installing monitor wells, collecting water level data from these monitor wells, and performing hydraulic testing of the properties, tailings source term characterization through pore water analyses, and periodic ground water quality analyses from select monitor wells. Attachment 3 provides details of these characterization efforts. The characterization programs conducted by DOE followed procedures outlined in the standard operating procedures for the UMTRA Project (JEG, n.d.) and the TAD (DOE, 1989).

Ground water quality was characterized by analyzing constituents listed in Table 8.1 of the TAD (DOE, 1989). The standard operating procedures for the UMTRA Project (JEG, n.d.) outline procedures for sampling, preserving, storing, and analyzing samples and include $\mathrm{OA}$ and $\mathrm{OC}$ protocols.

Attachment 3 provides a statistical treatment of ground water quality in the uppermost aquifer at both the processing and disposal sites. The statistical analyses include the minimum, mean, median, maximum, percentage of nondetects, and the 98-percent confidence interval for background, on-site, and downgradient ground water quality. Ground water quality can be characterized by describing an average concentration and a statistical maximum. The procedures for calculating average and statistical maximum concentrations are discussed in the Statistical Analysis of Ground-Water Monitoring Data at RCRA Facilities-Interim Final Guidance (EPA, 1989) and are described in the TAD. Average concentrations of hazardous constituents are represented statistically by a mean or median, depending on the proportion of nondetects, the distribution of the water quality data, and the number of samples available. The following guidelines apply:

- If the coefficient of variation of the data is greater than 1 , the distribution is assumed to be lognormal and the geometric mean is reported.

- If the coefficient of variation of the data is less than 1, the distribution is assumed to be normal and the arithmetic mean is reported. 
- If more than 15 percent of the data are below detection, the median is reported.

- If fewer than four samples are available, the median is reported. Distribution types are unknown if fewer than four samples are reported.

The statistical maximum is the upper limit of the 98-percent confidence interval for the true average concentration assuming normal or lognormal distributions. A nonparametric upper confidence interval is used if more than 15 percent of the data are below detection. If fewer than four samples are reported, the maximum observed concentration is chosen as a statistical maximum. When most of the data are below detection, the reported statistical maximum may be the detection limit divided by two, as computed by the UMTRA Software Program for Environmental Analysis and Reporting (SPEAR) system (DOE, 1992a). When the statistical values calculated are below the actual laboratory detection limits, the laboratory detection limits reported in Table $\mathbf{8 . 1}$ of the TAD (DOE, 1989) are applied.

\section{Processing sites}

Site-specific studies that addressed ground water at the Slick Rock NC and UC processing sites were initiated in 1981. Ford, Bacon \& Davis Utah Inc.

(FBDU, 1981) conducted an engineering assessment. The DOE initiated a reconnaissance investigation of the Slick Rock NC and UC sites in November 1984. Initial hydrogeologic characterization efforts at the processing sites continued through 1986. These investigations included the installation of six shallow monitor wells in the Dolores River alluvium, four deep monitor wells in the Navajo Sandstone, nine auger borings to the top of bedrock, and three test pits. From this limited hydrogeological characterization, it appeared that the Navajo Sandstone was confined by the Entrada Formation and an upward potentiometric gradient existed from the Navajo Sandstone Formation into the Entrada Formation.

Additional site characterization at the UC site continued during 1987. Related field activities included excavating 22 test pits, conducting surface geophysics, drilling 10 borings, and packer testing 2 boreholes in the Entrada Formation. The DOE drilled one borehole and installed three monitor wells in the Entrada Formation in 1989. Unconfined, near-surface ground water was encountered in these monitor wells. Additional drilling in the Entrada indicated the presence of buried paleochannels incised by the ancestral Dolores River. In August 1989, the DOE completed a seismic refraction survey across the UC processing site. In addition, the data produced from some of these field activities suggested that the Entrada Formation may not be laterally extensive across the site and may not completely separate the Dolores River alluvium from the Navajo Sandstone, as was previously thought.

To more accurately define these subsurface features, the DOE initiated a final site characterization drilling program. Monitor wells $(10)$ and exploratory 
boreholes (12) were installed in September 1989. This program identified 1) the locations, dimensions, and gradients of paleochannels; 2) numerous terraces associated with the incision of the Dolores River; 3) the presence of unconfined, near-surface ground water in the Entrada Formation and the Navajo Sandstone across parts of the UC processing site; and 4) the susceptibility of the Navajo Sandstone aquifer to contamination, due to localized erosion of the Entrada Formation confining beds. As a result, it was concluded that the Entrada Formation may not be a laterally extensive confining unit as was originally thought. Additional information regarding ground water occurrence and hydraulic properties is provided in Sections 3.1.3 and 3.1.4 of Attachment 3. Tables 3.1 and 3.2 of Appendix A of Attachment 3 provide monitor well construction information for the NC and UC processing sites, respectively. Appendix B of Attachment 3 provides lithologic logs and construction information for all DOE monitor wells.

Ground water elevations were measured and water table maps were constructed to determine the direction of ground water flow and hydraulic gradients. Slug tests were performed in the shallow alluvial material and in the Navajo Sandstone to estimate hydraulic conductivity. Sediment, tailings, surface water, ground water, and lysimeter pore fluid samples were collected at the NC and UC processing sites and analyzed to characterize existing conditions. Lysimeter pore fluid samples were analyzed to characterize the tailings source term. Ground water samples have been used to establish the nature and extent of contamination caused by uranium processing activities. The frequency and duration of sample collection is a function of when the monitor wells were installed, their proximity to the processing sites, and water quality data.

\section{Disposal site}

Three site-specific hydrologic investigations have been conducted in the vicinity of the Burro Canyon disposal site. In 1985, preliminary testing was conducted southeast of the current Burro Canyon disposal site location. Eight test pits and three boreholes were excavated to determine whether the location was suitable as a relocated disposal site. The area was found to be suitable for tailings disposal, as reported in the Comparative Analysis of Disposal Site Alternatives Report for the UMTRA Project Slick Rock Sites Located at Slick Rock, Colorado (DOE, 1986).

A second detailed site investigation was conducted during 1990 and 1991 at the current Burro Canyon site. During 1990, the DOE installed 16 monitor wells, 6 boreholes, and 20 test pits to characterize lithology, ground water elevations and hydraulic gradients, aquifer properties, and ground water quality at the disposal site.

Additional testing was conducted in 1991 in response to two issues raised by the Colorado Department of Health (CDH): 1) the extent of the mudstone aquitard between the upper and middle sandstone units of the Burro Canyon 
Formation southeast (downgradient) of the proposed disposal site; and 2) the degree of downgradient saturation in the upper sandstone unit. An exploration corehole was drilled approximately $900 \mathrm{ft}(300 \mathrm{~m})$ from the edge of the disposal cell to a total depth of $179 \mathrm{ft}(54.6 \mathrm{~m})$ below the surface. The exploration corehole confirmed that the Burro Canyon mudstone and sandstone units were continuous. A monitor well placed approximately $10 \mathrm{ft}(3 \mathrm{~m})$ north of the exploration corehole was completed to the base of the upper Burro Canyon sandstone unit for a total depth of $113 \mathrm{ft}(34.4 \mathrm{~m})$. A second monitor well, placed approximately $650 \mathrm{ft}(200 \mathrm{~m})$ southeast of the edge of the proposed disposal cell, was drilled through the upper sandstone unit (from 72 to $101 \mathrm{ft}$ [22 to $30.8 \mathrm{ml}$ ) and the mudstone aquitard (from 101 to $169 \mathrm{ft}$ [30.8 to $51.5 \mathrm{~mJ})$ and $10 \mathrm{ft}(3 \mathrm{~m})$ into the middle sandstone unit for a total depth of $179 \mathrm{ft}(54 \mathrm{~m})$. This well was then backfilled with bentonite and a screen was installed at the base of the upper sandstone unit from 80 to $100 \mathrm{ft}(20$ to $30 \mathrm{~m})$, with filter pack material from 65 to $102 \mathrm{ft}(20$ to $31.1 \mathrm{~m})$. Geophysical logs (natural gamma, gamma-gamma, neutron, and resistivity) were run in the exploratory borehole and five DOE monitor wells.

Table 3.42, Appendix A of Attachment 3, presents monitor well information. Appendix $B$ of Attachment 3 provides the lithologic logs and monitor well construction information.

The chemical and mineralogical properties of Burro Canyon sediment samples were characterized in 1990 by Pittsburgh Mineral \& Environmental Technology, Inc. (PMET, 1990). Sediment samples were collected from the Dakota Sandstone Formation (sandstones and shales) and from Burro Canyon Formation (mudstones and sandstones). The laboratory work included chemical analyses, polarized light microscopy with modal analyses, chemical analyses, and $X$-ray diffraction analyses.

Relatively undisturbed samples were recovered for visual inspection and laboratory tests to determine unsaturated hydraulic conductivity, porosity, and other selected parameters. Five sediment samples were collected from sandstones and shales of the Dakota Sandstone and mudstones and sandstones of the Burro Canyon Formation. Laboratory analyses were conducted to determine moisture contents, bulk densities, porosities, saturated hydraulic conductivities, soil moisture retention curves, and particle densities (Daniel B. Stephens \& Associates, Inc., 1991).

Ground water elevations were measured to map the potentiometric surface to determine the direction of ground water flow and hydraulic gradients. Bailer recovery tests, aquifer performance rests, and slug injection tests were conducted to determine hydraulic parameters of the upper, middle, and lower Burro Canyon sandstone units. Water quality samples collected from selected wells in the Burro Canyon sandstone units established background water quality at the disposal s..e. 


\subsubsection{Water use}

\section{Processing site}

A well survey conducted in Fobruary 1994 has indicated that 18 private wells currently or historically exist within a $2-\mathrm{mi}(3-\mathrm{km})$ radius of the Slick Rock UC and NC processing sites. Fourteen of these wells are registered with the Colorado Division of Water Resources, and the remaining four are nonregistered. Detailed information regarding private well locations, well permits, sampling dates, well construction, ground water units of completion, well status, and water use is provided in Appendix A to Attachment 3, Table 3.41. Well permit information indicates that the nearby private wells are screened in the alluvium. Entrada, and Navajo Sandstone Formations. The 1994 well survey has indicated that of the 18 private wells, 3 are actively used, 10 existing wells are presumed to be currently inactive, 3 wells adjacent to the site that could not be located in the field are presumed to be sealed, and the status of 2 registered wells located approximately $2 \mathrm{mi}(3 \mathrm{~km})$ east (upgradient of the processing sites) is unknown because of limited roadway access. Three private wells are downgradient of the UC site and are expected to be beyond the reach of the contaminant plume, as evidenced by the water quality in downgradient alluvial DOE monitor wells. The remainder of the wells are upgradient or crossgradient of the UC site. A ground water flow boundary appears to follow the course of the Dolores River and is expected to hydrologically separate these three wells from the NC tailings, which are on the opposite side of the Dolores River from the private wells.

In addition to the 18 private wells, a collector system that taps the Entrada Formation is located along a cliff face approximately $1500 \mathrm{ft}(450 \mathrm{~m})$ west (upgradient) of the UC site. This collector system appears in good shape and is believed to be used for livestock.

Staff from the Bureau of Land Management and U.S. Geological Survey have reported, as of February 1994, that they are unaware of any additional ground water users within $2 \mathrm{mi}(3 \mathrm{~km})$ of the Slick Rock processing sites.

Surface water from the Dolores River is another potential source of water in the processing site vicinity. The Dolores River will be the source of water used during remedial action construction. Rights to the surface water will be secured prior to surface remedial action construction.

\section{Disposal site}

No known registered or private wells are actively used within the upper sandstone unit of the Burro Canyon Formation within a $2-\mathrm{mi}(3-\mathrm{km})$ radius of the Burro Canyon disposal site.

Ground water development in the vicinity of the disposal site should not increase over the next $\mathbf{5 0}$ years, because not enough water is available to 
support development on any time scale. The first saturated hydrostratigraphic unit, the upper sandstone unit, has a low yield lless than 150 gpd $16.6 \times 10^{-3}$ $\mathrm{L} / \mathrm{s}]$ ), and is therefore classified as Class III (limited use) in accordance with Part 40 CFR $\$ 192.11(\theta)$ of the EPA ground water protection standards. By definition, Class III (limited use) ground water is not a current or potential source of drinking water.

\subsection{CONCEPTUAL CESIGN FEATURES FOR WATER RESOURCES PROTECTION}

This section summarizes the principal design features of the proposed disposal cell at the Burro Canyon disposal site. Section 3.3 describes in detail the design features of the proposed disposal cell. The design features will ensure compliance and do not rely on active maintenance to ensure adequate long-term performance. Additional details and specifications of the conceptual design are provided in Attachment 1.

The disposal cell will hold approximately $620,000 \mathrm{yd}^{3}\left(470,000 \mathrm{~m}^{3}\right)$ of contaminated material and cover an area approximately $610 \mathrm{ft}(190 \mathrm{~m})$ wide and $905 \mathrm{ft}(276 \mathrm{~m})$ long along the southwest face of the mesa. The height of the cell will range from $30 \mathrm{ft}(9 \mathrm{~m})$ to $50 \mathrm{ft}(15 \mathrm{~m})$ above the existing ground surface. The completed disposal cell will occupy an area of 12 ac (4.9 ha). A buffer area of 31 ac (13 ha) will bring the total area to 43 ac (17 ha). The DOE will schedule long-term surveillance of the disposal area.

The disposal cell cover will have a rock riprap surface layer and additional components below the rock. A detailed schematic of the cover is shown in Attachment 1, Drawings SRK-DS-10-0335 and SRK-DS-10-0336.

The design for the disposal embankment cover consists of the following layers, in descending order:

- Erosion protection layer. A layer of riprap (8 to 12 in $[0.2$ to $0.30 \mathrm{~m}]$ ) will prevent erosion of the disposal cell by surface water runoff.

- Bedding laver. A 6-in $(0.2-\mathrm{m})$ thick sand/gravel bedding layer will prevent displacement of large diameter rock, protect the underlying frost protection layer from erosion, and drain water laterally.

- Frost protection layer. A 2.0-ft $(0.61-\mathrm{m})$ thick frost protection layer, consisting of fine-grained soil with some sand, will protect the radon/infiltration barrier from the effects of freezing and thawing.

- Radon barrier layer. A 2.0-ft $(0.61-\mathrm{m})$ thick sandy clay radon barrier will inhibit radon emanation and reduce infiltration through the underlying contaminated material.

The material properties and available quantities for the cover materials have been adequately defined to conform with the applicable provisions of the SRP. 
In addition, the performance of the cover system has been evaluated using both state-of-the-art techniques and standard engineering methods. The results indicate the cover will remain effective for a period of time that is in compliance with the EPA standard 40 CFR $\$ 192.02$ for long-term performance.

Natural, stable materials have been proposed for use in constructing the Burro Canyon disposal cell to ensure long-term performance. Materials for the rock erosion protection layer have been selected, based on durability, suitability, and size, to perform adequately over the design life of the disposal cell. The compacted radon barrier material will be protected from erosion by the overlying cover components.

\subsection{DISPOSAL}

The proposed EPA standards in Subparts A and C of 40 CFR Part 192 require information and assessments to demonstrate that the disposal of RRM complies with ground water protection and performance standards. The required information and assessments can be categorized as follows: the ground water protection standard (see Section 5.3.1); a performance assessment and a closure performance standard (see Section 5.4); and a monitoring and corrective action program (see Section 5.5). The purpose of the ground water protection and performance standards is to establish the minimum acceptable performance of the disposal and control of RRM to prevent or control future releases of hazardous constituents. The performance assessment confirms the adequacy of the disposal cell and provides corrective action that may be necessary if the disposal cell does not perform adequately (NRC, 1989). The following sections describe in detail the four components of the ground water protection and performance standards.

\subsubsection{Ground water protection standard for disposal}

The Burro Canyon disposal cell is designed to control radioactive materials and nonradioactive contaminants as required by the proposed EPA ground water protection standards in 40 CFR $\$ 192.02$ (a)(3). The proposed ground water protection compliance strategy applies supplemental standards for Class III (limited use) ground water. Protection of human health and the environment will be achieved because the uppermost aquifer has a low vield lless than $\left.150 \mathrm{gpd}\left[6.6 \times 10^{-3} \mathrm{~L} / \mathrm{s}\right]\right)$, as demonstrated in on-site aquifer performance tests. No known potable water supply wells exist within the uppermost aquifer in a $2-\mathrm{mi}(3-\mathrm{km})$ radius of the disposal site. The uppermost aquifer is hydrogeologically isolated from underlying saturated units by thick $125-$ to $75-\mathrm{ft}$ [7.6- to 23-m]) mudstone units and by significant upward vertical hydraulic gradients. A narrative supplemental stan lard is provided in Section 5.3.2.

The ground water protection standard consists of three components: 1) a list of hazardous constituents, 2) a corresponding list of concentration limits for the constituents, and 3 ) a point of compliance (POC) (NRC, 1989). The DOE has identified hazardous constituents in the tailings pore fluids measured in lysimeter 
samples and in shallow alluvial ground water at the processing sites. For this narrative supplemental standard application, no concentration limits or POCs have been established for the identified potentially hazardous constituents because the uppermost aquifer at the proposed Burro Canyon disposal site meets the insufficient vield criteria of Class III (limited use) ground water, as defined in 40 CFR $\$ 192.11(e)$ of the EPA-proposed ground water standards. There is no historic or current beneficial use of ground water in the upper sandstone unit of the Burro Canyon Formation. As a result, defining concentration limits and a POC would not further protect human health and the environment. A demonstration that the remedial action is as close as reasonable to meeting the otherwise applicable standard is presented in Section 5.3.2.

\section{Hazardous constituents}

Hazardous constituents at the Burro Canyon disposal site were identified from characterization of the tailings materials. A description of the uranium recovery process and an evaluation of ground water quality data are included in Attachment 3.

Hazardous constituents potentially of concern at the Burro Canyon site have been determined, based on two criteria: 1) they must be present in (or reasonably expected to be present in) or derived from the RRM to be stabilized at the disposal site; and 2) they must be constituents listed in the proposed EPA ground water protection standards (52 FR 36000 (1987)).

Average concentrations or activities of eight inorganic hazardous constituents with MCLs that 1 ) are related to uranium processing activities, and 2) exceeded laboratory method detection limits in the lysimeter pore fluid samples from the NC or UC sites include arsenic, cadmium, lead, molybdenum, net gross alpha, nitrate, selenium, and uranium. Six additional hazardous constituents without MCLs that exceeded the laboratory method detection limits are antimony, copper, thallium, tin, vanadium, and zinc. Table 5.3 summarizes the hazardous constituents identified at the Slick Rock processing sites.

Ground water at the processing site was screened for the organic hazardous constituents. One organic screening ground water sample was collected froin a DOE monitor well at the NC processing site and another was collected from a DOE monitor well at the UC processing site. No organic hazardous constituents were detected in the monitoring well sample collected from the UC processing site. Two organic compounds were detected in the NC ground water sample; however, the concentrations of the detected organic compounds are believed to be the result of laboratory contamination, rather than from the processing operations at the NC site. Additional discussion is provided in Section 3.1.6 of Attachment 3.

The DOE has evaluated the potential effects of relocating the tailings to the Burro Canyon disposal site and has determined that because the uppermost aquifer has a low yield (less than $150 \mathrm{gpd}\left[6.6 \times 10^{-3} \mathrm{~L} / \mathrm{s}\right]$ ) and is not a current 


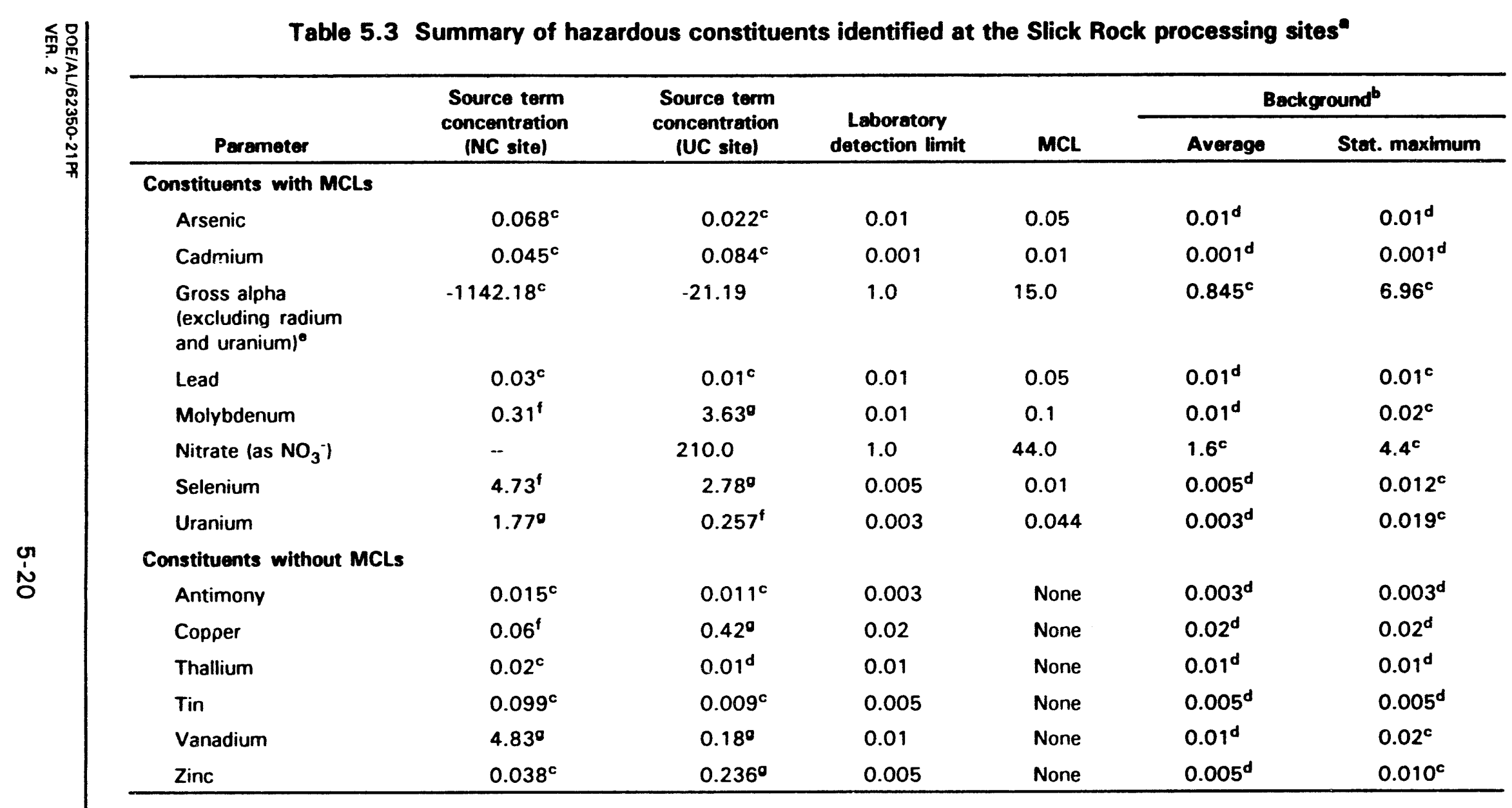

-All units are milligrams per liter (mg/L) unless otherwise noted. Source term concentrations are based on lysimeter samples collected from January 1989 to October 1992.

background ground water quality in the Burro Canyon Formation, upper unit (uppermost aquifer).

'Nonparametric distribution.

'Statistical values are below laboratory detection limits in Table 8.1 of the Technical Approach Document (DOE, 1989).

- Units are picocuries per liter (pCi/L).

Normal distribution, mnan is arithmetic.

'Lognormal distribution, mean is geometric. 
or potential source of water, hazardous constituents from the tailings source term will not affect human health and the environment. The disposal cell will minimize release of the potentially hazardous constituents identified in Table 5.3. Approximately 50 to $65 \mathrm{ft}(15$ to $20 \mathrm{~m})$ of low-permeability $(2.3 \times$ $10^{-6} \mathrm{~cm} / \mathrm{s}\left[6.5 \times 10^{-3} \mathrm{ft} /\right.$ day $]$ interbedded mudstone and siltstone sequences will separate the base of the disposal cell from the uppermost aquifer (upper sandstone unit of the Burro Canyon Formation). The upper sandstone unit is hydrogeologically separated from the middle sandstone unit by another 60 to $70 \mathrm{ft}$ (about $20 \mathrm{~m}$ ) of mudstone and by an upward vertical gradient. As a result, if any potentially hazardous constituents are released below the disposal cell foundation, the low-permeability mudstone and siltstone sequences are expected to limit further migration. Therefore, the disposal cell design should result in human health standards being met in the first potentially usable aquifer beneath the disposal cell (the middle unit of the Burro Canyon Formation). Additional discussion of potential points of exposure is presented in Section 5.3.3. The uppermost aquifer is hydrogeologically isolated from the underlying water bearing units by low-permeability mudstone and upward vertical gradients, as discussed in Attachment 3.

\section{Proposed concentration limits}

To achieve compliance with the proposed EPA ground water protection standards at the disposal site, the DOE proposes to apply a narrative supplemental standard based on Class III (limited use) ground water due to insufficient yield in the uppermost aquifer. A narrative supplemental standard is reasonable for the Burro Canyon disposal site for the following reasons:

- The quantity of water available is less than $150 \mathrm{gpd}\left(6.6 \times 10^{-3} \mathrm{~L} / \mathrm{s}\right)(40$ CFR $\$ 192.11(\mathrm{e})(3))$, as demonstrated by on-site aquifer performance testing.

- There is no historic or existing beneficial use of the ground water in the uppermost aquifer, due to limited yield.

- The proposed disposal cell foundation will be separated from the uppermost aquifer by a thick layer of low-permeability mudstone ( 25 to $75 \mathrm{ft}$ [ 7.6 to $23 \mathrm{ml}$ ).

- Ground water in the sandstone units underlying the uppermost aquifer is protected from potential site-related contamination by the low-permeability mudstone units that inhibit the downward migration of water and steady state upward vertical hydraulic gradients in the lower and middle sandstone units of the Burro Canyon Formation.

- There is rio evidence of discharge anywhere in the vicinity of the site; therefore, there is no point of exposure. 
- The proposed remedial action at the Burro Canyon disposal site comes as close to meeting the otherwise applicable standards (40 CFR Part 192) as is reasonable under the circumstances (see Section $\mathbf{5 . 2}$ for a discussion of disposal cell design features for protection of ground water). A discussion of how the remedial action at the Burro Canyon disposal site will protect human health and the environment is provided in Section 5.3.3.

\section{Point of compliance}

A POC has not been established for the proposed Burro Canyon disposal site for the reasons previously discussed.

\subsubsection{Narrative supplemental standard}

The NRC must consider the following four items before granting supplemental standards (NRC, 1989); 1) the criteria for applicability, 2) description of the supplemental standard, 3 ) demonstration that the remedial action satisfies the proposed supplemental standard, and 4) demonstration that the supplemental standard is as low as reasonable under the circumstances. Items 1, 3, and 4 are discussed in this section. Item 2 is discussed in Section 5.3.1.

\section{Applicability criteria}

To achieve compliance with the proposed EPA ground water protection standards, the DOE proposes the application of a narrative supplemental standard (Subpart C of 40 CFR Part 192) at the Burro Canyon disposal site. Ground water in the uppermost aquifer meets the definition of Class III (limited use (40 CFR §192.11(e)) based on insufficient yield and ground water use. These criteria are discussed below.

The EPA defines "sufficient yieis" as a quantity of water from a well or spring sufficient to meet the long-term needs of an average family (EPA, 1986). The yield must be sustainable into the future. The EPA has estimated that the lowest quantity that meets this requirement is $150 \mathrm{gpd}\left(6.6 \times 10^{-3} \mathrm{~L} / \mathrm{s}\right)$. Ground waters with yields less than this criterion are defined as Class III (limited use).

The ground water protection standards in 40 CFR $\$ 192.02(a)(3)$ apply to the uppermost aquifer hydraulically downgradient from the disposal unit. The upper sandstone unit of the Burro Canyon Formation is the uppermost aquifer at the Burro Canyon disposal site. Ground water in this unit occurs under semiconfined conditions at constant levels and does not show seasonal fluctuations. The upper sandstone unit is not a current or potential source of drinking water because the quantity of water available is less than $150 \mathrm{gpd}$ (6.6 $\times 10^{-3} \mathrm{~L} / \mathrm{s}$ ), as evidenced by on-site aquifer performance tests. As a result, the ground water in the upper sandstone unit is limited use, or Class III ground water, as defined in 40 CFR $\$ 192.11(e)$ of the EPA's proposed ground water standards. Furthermore, the upper sandstone unit is hydrogeologically isolated 
from the underlying middle and lower sandstone units, as discussed in Section 3.2.3 of Attachment 3.

By definition, Class III (limited use) ground water is not a current or potential source of drinking water. No known registered or private wells are actively used within the upper sandstone unit of the Burro Canyon Formation in a 2-mi $(3-\mathrm{km})$ radius of the Burro Canyon disposal site, because of limited yield. Furthermore, ground water development in the vicinity of the disposal site should not increase over the next 50 years, because there is not enough water available to support development on any time scale.

\section{Demonstration that remedial action satisfies the proposed supplemental standard}

This section describes potential impacts of ground water use to human health and the environment. There are no historic or existing beneficial uses of ground water in the upper sandstone unit of the Burro Canyon Formation, based on the applicability criteria discussed above.

Human health and the environment will be protected for the following reasons:

- The quantity of water available is less than $150 \mathrm{gpd}\left(6.6 \times 10^{-3} \mathrm{~L} / \mathrm{s}\right)(40$ CFR \$192.11(e)(3)), preventing future ground water development and use.

- Ground water in the uppermost aquifer beneath the proposed Burro Canyon disposal site is not a current or potential source of drinking water.

- The proposed disposal cell foundation will be separated from the uppermost aquifer by 25 to $75 \mathrm{ft}(7.6$ to $23 \mathrm{~m})$ low-permeability mudstone.

- The first potentially usable aquifer beneath the disposal site, the middle sandstone unit, will meet human health standards because it is separated from the disposal cell by over $100 \mathrm{ft}(30 \mathrm{~m})$ of mudstone (including the upper and middle mudstone units of the Burro Canyon Formation, collectively) and steady-state upward vertical hydraulic gradients in the middle and lower sandstone units, thus inhibiting the downward migration of water.

- There is no point of exposure downgradient of the disposal site. Details are provided in Section 5.3.3.

\section{As low as reasonable under the circumstances}

The proposed disposal cell design meets the as low as reasonable under the circumstances criterion. The design features, described in Section 5.2, will ensure that human health and the environment are protected. Active maintenance will not be required to ensure long-term performance. The proposed disposal embankment cover will use natural, stable materials to 
prevent surface erosion, provide protection against freezing and thawing, and inhibit radon emanation and water seepage, by incorporating design features that are as close to meeting the otherwise applicable standards as are reasonable under the circumstances.

\subsubsection{Point of exposure}

Pursuant to 40 CFR Part 192, this section assesses the potential for human and environmental exposure and concludes that the probability of exposure is low enough to prevent adverse impacts from ground water contamination. For the purposes of this discussion, points of exposure can be divided into two categories: 1) surface expressions where water enters the uppermost aquifer as precipitation and outflows as surficially exposed drainage, and 2) subsurface drainage.

\section{Surface points of exposure}

The upper sandstone unit is recharged by infiltration of water from the surface outcrop upgradient of the site. Sandstone beds outcrop along the east limb of the Disappointment syncline and intercept tributaries to the Nicholas Wash drainage system. Ground water movement in the upper sandstone unit parallels the axis of the Disappointment syncline and eventually dissipates (discharges) into the Burro Canyon Formation southeast of the disposal site (Figure 5.5). The Burro Canyon Formation has a grade of approximately 3 percent. The Joe Davis Canyon is about $1 \mathrm{mi}(2 \mathrm{~km})$ south of the disposal site. Based on a cross section shown in Figure 5.6 (modified from Shawe et al., 1968), the upper sandstone unit of the Burro Canyon Formation is present only as a cap at the top of the Joe Davis Canyon. Any potential seepage into the Joe Davis Canyon from the Burro Canyon Formation is expected to be from the middle and/or lower Burro Canyon sandstone units. Furthermore, based on the direction of ground water movement, the Joe Davis Canyon is crossgradient from the Burro Canyon disposal cell. Therefore, any potential leachate from the disposal cell would never reach Joe Davis Canyon.

Additional potential points of exposure include two thin sandstone layers of the Dakota Sandstone Formation that outcrop at the base of the disposal cell mesa within 200 to $300 \mathrm{ft}(60$ to $90 \mathrm{~m})$ of the toe of the disposal cell. As the Dakota Formation is incised during disposal cell construction, the lateral migration of contaminated pore fluid through relatively permeable sandstone layers is a potential concern. An investigation was conducted to assess whether contaminated fluid could leach from the disposal cell through the thin sandstone layers of the Dakota Formation and form seeps where the layers outcrop at the base of the small mesa (Appendix C to Attachment 3, Calculation SRK-11-9312-06-00). Data collected from the Burro Canyon disposal site, laboratory tests, and measurements reported in the literature were used in this seepage assessment. These measurements provide the basis for qualitative comparison with materials from other tailings disposal sites and comparison with hydrologic modeling results from other studies. The quantitative evaluation summarizes 


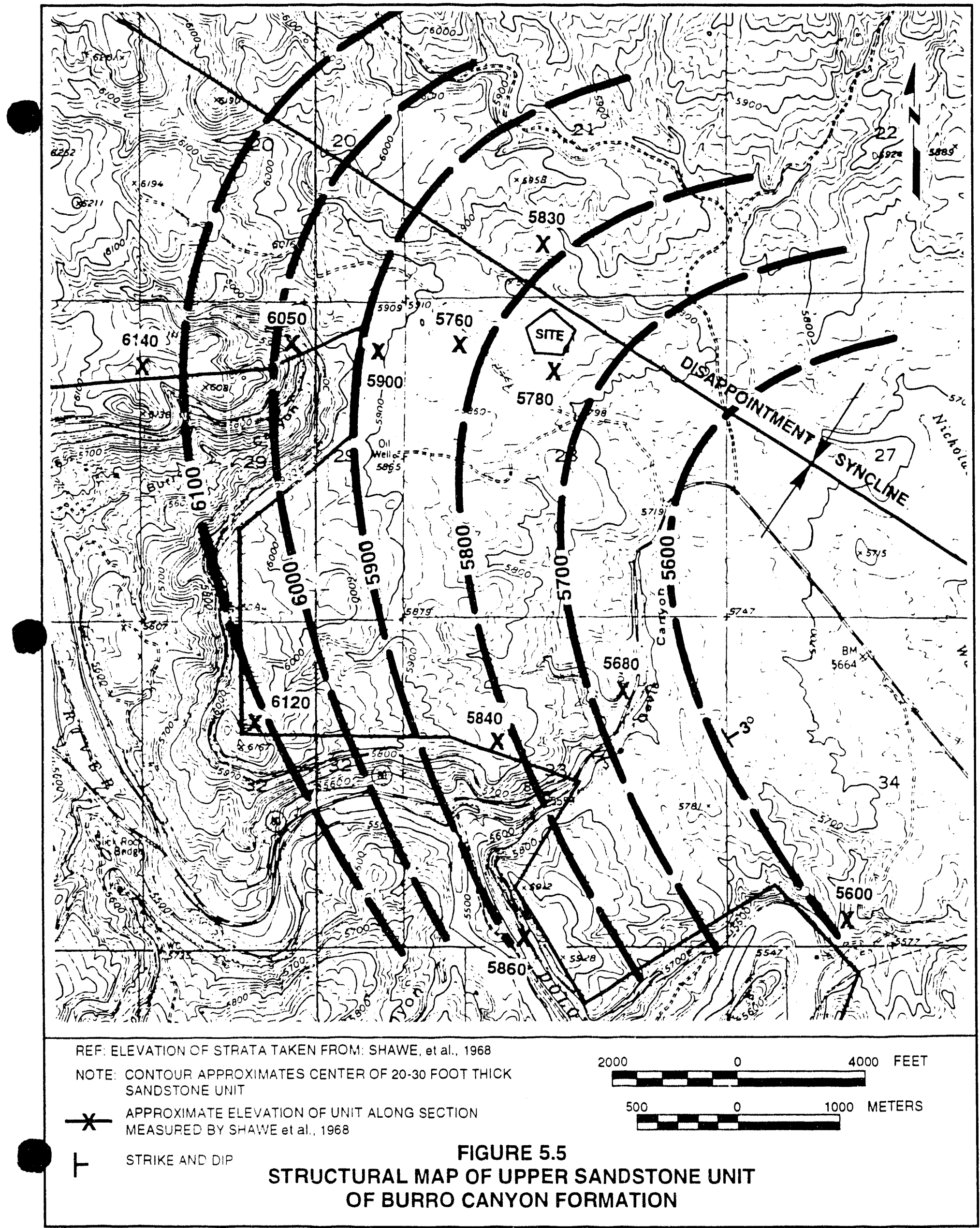




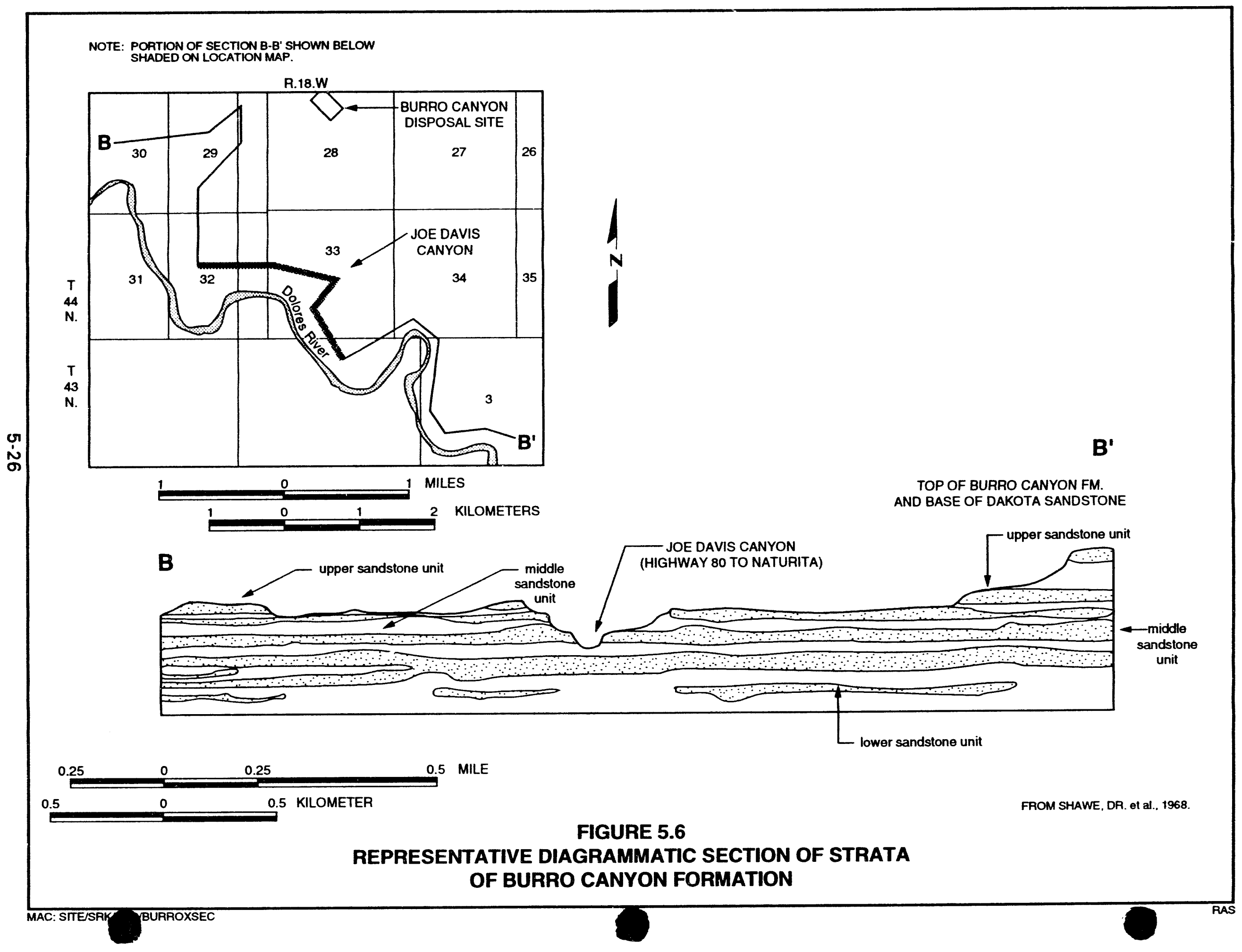


the physical properties, including hydraulic characteristics, of both contaminated and uncontaminated material. The qualitative assessment discusses the drainage characteristics of the contaminated material and compares the Slick Rock disposal cell design and materials with a similar design at Morton Ranch, Wyoming, that was evaluated and modeled by Pacific Northwest Laboratories (PNL, 1980). Remaining issues that may have some impact for the potential for lateral seepage, including the cover flux and the formation of a saturated zone above the interface of the natural foundation materials (mudstones and claystones of the lower Dakota Sandstone Formation and top of the Burro Canyon Formation) and the tailings, was addressed by using the UNSAT2 (NRC, 1983) computer code and evaluating the results. Details of this investigation are provided in Calculation SRK-11-93-12-06-00 and are summarized below:

- Given that the sand tailings are very dry (level of saturation is less than 20 percent) and little water addition is required to meet either compaction or dust control requirements, almost no water is available to cause lateral or vertical seepage.

- The one-dimensional (UNSAT2) vertical profile model runs have demonstrated that the moisture contents at which the tailings and other contaminated material are placed have a profound impact on the maximum height of the saturated zone. Low moisture contents for material placed in a disposal cell greatly reduces the volume of water available for creating a saturated zone (pond) at the contact of the Burro Canyon Formation.

- Based on the UNSAT2 model results, the permissible range of saturated hydraulic conductivities of the radon/infiltration barrier is $10^{-6}$ to $10^{-7} \mathrm{~cm} / \mathrm{s}$, with an average value of $5 \times 10^{-7} \mathrm{~cm} / \mathrm{s}$.

- The disposal cell design calls for excavating approximately 6.0 to $7.5 \mathrm{ft}(2.0$ to $2.5 \mathrm{~m}$ ) into the claystones and mudstones at the base of the Dakota Sandstone Formation and Burro Canyon upper mudstone unit. These natural foundation materials will cut off any potential pathways of seepage and create a liner effect.

- The excavated mudstone/claystone will provide an impermeable layer from the base of the pit to approximately 2.0 to $2.5 \mathrm{~m}$ up the side wall, effectively forming a continuous saucer-shaped bottom and side liner. These natural low-permeability mudstone and claystone materials will further mitigate any potential of a saturation front moving into the sandstone stringers of the Dakota Formation.

This investigation and others (PNL, 1980) have demonstrated that the relatively small volume of leachate from the dry sand tailings will not create seeps at the base of the mesa at the proposed Burro Canyon disposal site. 


\section{Subsurface points of exposure}

Subsurface drainage potentially could result from transient drainage of excess moisture from the tailings. The tailings at the Slick Rock sites consist of sand and poorly graded sand with silt. The tailings saturated hydraulic conductivity is approximately $140 \mathrm{ft} /$ day $\left(4.9 \times 10^{-2} \mathrm{~cm} / \mathrm{s}\right)$, which is characteristic of a clean, free-draining sand (Freeze and Cherry, 1979). As a result, the tailings will have a low moisture content when they are placed in the disposal cell. This low moisture content of the RRMs, coupled with a 2-ft $(0.6-\mathrm{m})$ thick radon barrier, will inhibit radon emanation and water seepage through the underlying contaminated material.

Approximately 50 to $65 \mathrm{ft}(15$ to $20 \mathrm{~m})$ of low-permeability $\left(6.5 \times 10^{-3} \mathrm{ft} / \mathrm{day}\right.$ $\left.\left[2.3 \times 10^{-6} \mathrm{~cm} / \mathrm{s}\right]\right)$ interbedded mudstone and siltstone sequences will separate the base of the disposal cell from the upper sandstone unit of the Burro Canyon Formation. Ground water in lithologic units underlying the uppermost aquifer is also protected from potential seepage from the disposal cell by 1) hydrogeologic isolation, provided by the low-permeability Burro Canyon mudstone units that inhibit the downward migration of water, and 2) upward vertical hydraulic gradients in the lower and middle sandstone units of the Burro Canyon Formation.

\subsection{PERFORMANCE ASSESSMENT AND DEMONSTRATION}

The DOE is required to demonstrate that the performance of the disposal cell will comply with the EPA ground water protection standard (40 CFR $\$ 192.02(a)(3))$. To achieve compliance, the DOE proposes to apply supplemental standards, because the uppermost aquifer is not a current or potential source of drinking water due to limited vield.

Aquifer performance testing has been conducted at the proposed Burro Canyon disposal site to assess the hydraulic properties and amount of interconnection between the saturated units of the Burro Canyon Formation. The results of these and other site-specific hydrogeologic investigations (described in Attachment 3) demonstrate that ground water is protected from potential siterelated contamination in the upper sandstone unit of the Burro Canyon Formation (uppermost aquifer) and in the underlying sandstone units. Hydrogeologic isolation is provided by the low-permeability mudstone units above and below the uppermost aquifer and by upward vertical hydraulic gradients in the middle and lower sandstone units of the Burro Canyon Formation.

The DOE has demonstrated that the proposed RAP at the disposal site will comply with Subpart A (40 CFR Part 192) of the proposed ground water protection standards. The disposal cell will minimize the release of hazardous constituents to ground water and surface water and of radon emissions to the atmosphere to the extent necessary to protect human health and the environment (40 CFR $\$ 192.02(a)(4)$ ). Natural, stable materials have been 
proposed for use in the construction of the disposal cell so that long-term performance is ensured (see Section 3.3). The DOE also has demonstrated that design features necessary for compliance with the ground water protection standards minimize the need for further disposal site maintenance. Because sustainable amounts of ground water are not available from the upper sandstone unit, no existing or potential users are in the area.

\subsection{GROUND WATER MONITORING}

Pursuant to 40 CFR $\$ 192.02$ (a)(4)(b), this section addresses a ground water monitoring plan to be carried out during and after the remedial action period. The DOE has determined that proposing concentration limits and monitoring a POC at the Burro Canyon disposal site would not further protect human health and the environment for the reasons discussed in Sections 5.3.1 and 5.3.2. An assessment of the potential effects to human health and the environmental exposure and a determination that the probability of exposure will be low enough to prevent adverse impacts from ground water contamination are provided in Section 5.3.3. Points of exposure have been divided into two categories: 1) surface expressions where the source of recharge is precipitation and discharge is surficially exposed drainage, and 2) subsurface drainage. Ground water monitoring would not be effective at the Burro Canyon disposal site, and is therefore not proposed, because insufficient yield in the uppermost aquifer will preclude its future use. The only point of exposure that could potentially affect human health or the environment would be surface seepage at the base of the disposal cell mesa. In lieu of ground water monitoring, the DOE will conduct long-term surveillance monitoring by conducting inspections to locate surface expressions of seepage at and in the vicinity of the Burro Canyon disposal site. These visual inspections will include looking for physical evidence of mineralization, phreatophyte vegetation, and the presence of saturated zones at sandstone outcrops.

\subsection{GROUND WATER CLEANUP}

The DOE is responsible for demonstrating compliance of cleanup or control of existing processing-related ground water contamination at the Slick Rock sites with the proposed EPA ground water protection standards in Subpart B of 40 CFR Part 192.

\subsubsection{Ground water cleanup standard}

The current level of site characterization is sufficient to address only whether remedial action will comply with the draft final EPA ground water protection standards. The DOE has decided that aquifer restoration (ground water cieanup) will be addressed under a separate DOE program and will be part of a separate National Environmental Policy Act process. Additional ground water characterization may be conducted to include water quality, ground water flow, and aquifer properties. A conceptual ground water restoration strategy will be developed. 
The current level of characterization at the Slick Rock processing sites is sufficient to address only whether the remedial action will comply with Subpart A of the proposed EPA ground water protection standards. Additional investigations will be conducted as necessary to determine the appropriate ground water cleanup strategy for the Slick Rock processing sites. The proposed surface remedial action will not preclude or interfere with any potential ground water remediation activities at these processing sites.

\subsubsection{Cleanup demenstration}

Demonstration of cleanup and control of existing processing-related ground water contamination will be addressed under a separate DOE UMTRA Program and will be part of a separate process to comply with the National Environmental Policy Act. The proposed remedial action will not preclude or interfere with active ground water restoration at the processing sites, should it be required, because the tailings will be relocated to a remote disposal site.

\subsubsection{Cleanup monitoring program}

Ground water monitoring and site characterization will continue at the processing sites, as needed. Procedures for collecting, handling, and analyzing ground water samples are outlined in the UMTRA Project standard operating procedures (JEG, n.d.) on file at the UMTRA Project Albuquerque Operations Office.

\section{W.7 WATER RESOURCES PROTECTION STRATEGY SUMMARY}

To achieve compliance with the proposed EPA ground water protection standards (Subpart A of 40 CFR Part 192), the DOE proposes to apply supplemental standards for Class III (limited use) ground water because of low yield (less than $\left.150 \mathrm{gpd}\left(6.6 \times 10^{-3} \mathrm{~L} / \mathrm{s}\right)\right)$ in the uppermost aquifer. The proposed remedial action will ensure protection of human health and the environment. A summary of the principal features of the water resources protection strategy for the Burro Canyon disposal site follows.

- Uranium tailings and associated contaminated materials at the UC and NC mill sites will be consolidated and relocated to the Burro Canyon disposal site. These materials will be placed in a partially below-grade disposal cell designed to reduce radon emanation, resist degradation, reduce infiltration, and withstand differential settlement.

- The disposal cell foundation and the site location have been optimized to utilize favorable hydrogeologic and geochemical conditions of the site. A multiple-component cover has been included. The design for the disposal embankment cover consists of the following layers, in descending order: 1) riprap, to prevent erosion of the disposal cell by surface water runoff; 2) a sand and gravel bedding layer, to prevent displacement of large diameter rock, protect the underlying frost protection layer from erosion, 
and drain water laterally; 3) a frost protection layer (fine-grained soil with some sand), to prctect the radon/infiltration barrier from the effects of freezing and thawing; and 4) a thick sandy clay radon barrier, to inhibit radon emanation and infiltration through the underlying contaminated material. The base of the cell will be excavated into the low-permeability claystone and mudstones to provide an impermeable barrier to vertical migration. These same natural foundation materials will be used to line (will function as a liner) the side walls from the pit bottom and extending 2.0 to $2.5 \mathrm{~m}$ upward to inhibit latera! seepage.

- Low moisture contents in the sand tailings (level of saturation less than 20 percent) and little addition of water during construction will limit the volume of water available for creating a saturated zone (pond) at the contact of the Burro Canyon Formation.

- The proposed ground water protection compliance strategy applies supplemental standards. The demonstrated quantity of water available from the uppermost aquifer is less than $150 \mathrm{gpd}\left(6.6 \times 10^{-3} \mathrm{~L} / \mathrm{s}\right)$ and is classified as Class III (limited use) because it refers to ground water that is not a current or potential source of drinking water.

- Ground water in lithologic units underlying the upper sandstone unit of the Burro Canyor Formation (uppermost aquifer) is protected irom potential siterelated contamination by 1) hydrogeologic isolation provided by the lowpermeability mudstone units that inhibit the downward migration of water, and 2) upward $v \quad$ hydraulic gradients in the lower and middle sandstone units urro Canyon Formation.

- Ground water monitoring woulij not be effective at the Burro Canyon disposal site, and is therefore not proposed, because insufficient yield in the uppermost aquifer will preclude its future use. The only point of exposure that could potentially affect human health or the environment would be surface seepage at the base of the disposal cell mesa. In lieu of ground water monitoring, the DOF will conduct compliance monitoring by conducting inspections to locate surface expressions of seepage at and in the vicinity of the Burro Canyon disposal site. These visual inspections will include louking for physical evidence of mineralization, phreatophyte vegetation, and the presence of saturated zones at sandstone outcrops.

- Demonstration of cleanup and control of existing processing-ralated ground water contamination at the UC and NC sites will be addressed under a separate DOE UMTRA Project program and will be part of a separate process to comply with the National Environmental Policy Act. The proposed surface : emedial action will not preclude or interfere with active ground water restoration at the processing site, should it be required, because the tailings will be relocated to a remote disposal site. 


\subsection{RADON ATTENUATION AND SITE CLEANUP}

\subsection{INTRODUCTION}

This section summarizes the disposal cell design and relevant parameters used to evaluate the radon barrier, site radiological characteristics, and radiological survey plan to provide reasonable assurance that compliance with the EPA standards outlined in 40 CFR Part 192 (1993) will be achieved.

\subsection{DESIGN}

The proposed remedial action will consolidate contaminated materials from the NC and UC areas within the boundaries of the designated Slick Rock sites into a single disposal cell at the Burro Canyon site. The approximate volume of these contaminated materials is $620,000 \mathrm{yd}^{3}\left(470,000 \mathrm{~m}^{3}\right)$. In addition, an estimated $3000 \mathrm{yd}^{3}\left(2000 \mathrm{~m}^{3}\right)$ of uncontaminated demolition debris from the recreation building, other site structures, and on-site scrap materials will be disposed of in the main disposal cell. Efforts will be made to place materials with relatively low Ra-226 concentrations over materials with higher concentrations. A compacted (95 percent) earthen radon barrier 24 in $(0.60 \mathrm{~m})$ thick will be placed directly over the contaminated material. The sequencing of contaminated material within the cell and cover replacement will reduce the radon flux to below the EPA standards, to levels that are as low as reasonably achievable (ALARA).

Additional cover components will be sequentially placed above the primary earthen radon barrier. On the gradual topslope, these components will consist of a $2.0-\mathrm{ft}(0.61-\mathrm{m})$ thick frost protection layer, a 6 -in $(0.2-\mathrm{m})$ thick bedding layer, and an 8-in $(0.2-\mathrm{m})$ thick riprap layer. The sideslopes will contain the same layers as the topslope; however, the sideslo oe riprap layer will be $1.0 \mathrm{ft}$ $(0.3 \mathrm{~m})$ thick.

The radon barrier, frost protection layer and bedding layer will all contribute to the reduction of surface radon flux; however, to be conservative, only the radon barrier was considered in the radon flux attenuation calculations.

\subsection{RADON BARRIER PARAMETERS}

The radon barrier design parameters and supporting calculations were used in conjunction with the RAECOM model (NRC, 1984) to determine the cover thickness needed to control radon flux to meet the EPA standard of $20 \mathrm{pCi} / \mathrm{m}^{2} \mathrm{~s}$. Procedures for determining the thickness of the radol barrier are described in the TAD (DOE, 1989).

Specific parameters discussed below include long-term moisture content, radon diffusion, radon emanation, bulk density, specific gravity, porosity, layer thickness, and average Ra-226 concentrations. The RAECOM input parameters 
for the Slick Rock materials are presented in Attachment 1, Calculation 11-321-01-00 (Radon Barrier Design).

As of the date this calculation was performed, analytical test data for the radon barrier material properties were incomplete. Some assumptions and empirical correlations have been used while additional field investigation and analytical testing are conducted. The radon barrier design parameters will be verified and/or revised upon completion of the additional investigation.

\subsubsection{Leng-term moisture}

The average long-term moisture content for the earthen radon barrier and contaminated material was determined by using the optimum and capillary moisture content, the Rawls procedure, and the in situ residual moisture. In general, the lowest value obtained from the tests was selected to characterize the radon barrier. Four radon barrier soil samples from the Disappointment Valley borrow site were tested separately. The in situ residual moisture content was compared to the minus 15 bar capillary moisture content for the same sample, and the lower value was selected as the long-term moisture content of the sample. The average long-term moisture content was calculated to be 11.6 percent by weight using selected values of each sample.

Separate sample sets were tested from each of the representative areas of contamination to determine their respective long-term moisture content: the NC site (two samples) and the UC site (five samples). In situ moisture tests on these samples yielded values that are at or near typical residual moisture content values for similar materials. Therefore, minus 15 bar capillary suction measurements were not conducted on these samples. The volume-weighted average moisture contents for the NC site and UC site were 8.5 and 6.2 percent moisture by weight, respectively.

\subsubsection{Radon diffusion}

Average radon diffusion coefficients for the earthen radon barrier material and contaminated materials were determined using four different cover soil samples and three and four soil samples from the NC and UC contaminated areas, respectively. Radon diffusion for each type of material was measured in the laboratory as a function of moisture content. For each soil sample, between three and six diffusion measurements were made, each at a different moisture content within the moisture content range. Test results for the cover and contaminated materials were plotted separately, and a best fit to an analytical model curve was obtained for each material category using a least squares methodology. An average radon diffusion coefficient of $1.1 \mathrm{E}-02 \mathrm{~cm}^{2} / \mathrm{s}$ was derived for the earthen component of the radon barrier at 54-percent saturation (11.6 percent by weight). Diffusion coefficients of $2.9 \mathrm{E}-02$ and $1.9 \mathrm{E}-\mathrm{O}-\mathrm{Cm} \mathrm{cm}^{2} / \mathrm{s}$ were estimated for the UC tailings and offpile, respectively. A diffusion coefficient of $1.9 \mathrm{E}-02 \mathrm{~cm}^{2} / \mathrm{s}$ was estimated for the contaminated material from 
the NC site. Each diffusion coefficient value selected corresponds to the individual estimated long-term moisture content for the effective material.

\subsubsection{Radon emanation}

In general, radon emanation has been shown to be statistically independent of both moisture and Ra-226 concentrations using standard regression and statistical analysis. Twelve standard measurements of radon emanation for NC tailings-contaminated materials ranged from 0.23 to 0.62 , with an arithmetic average of 0.42 and a standard error of the mean of \pm 0.03 . Fourteen standard measurements of radon emanation for UC tailings-contaminated materials ranged from 0.10 to 0.29 , with an arithmetic average of 0.19 and a standard error of the mean of \pm 0.02 . Nine standard measurements of radon emanation for UC offpile-contaminated materials ranged from 0.31 to 0.59 , with an arithmetic average of 0.45 and a standard error of the mean of \pm 0.03 .

\subsubsection{Dry densities and porosities}

The dry densities, specific gravities, and porosities for the earthen radon barrier and contaminated materials were determined using standard tests, assuming a design compaction of 95 and 90 percent, respectively. Radon barrier soils had maximum dry densities ranging from 1.75 to 1.90 grams per cubic centimeter $\left(\mathrm{g} / \mathrm{cm}^{3}\right)$ and specific gravities of 2.67 to 2.80 , for separate measurements made on seven and five cover soil samples, respectively. An average density at 95-percent compaction of $1.73 \mathrm{~g} / \mathrm{cm}^{3}$ and an average specific gravity of 2.74 were used to obtain a representative porosity of 0.37 for the radon barrier.

Thirty contaminated material samples were tested for maximum dry density (22) and specific gravity (31), and measured values ranged from 1.53 to $1.94 \mathrm{~g} / \mathrm{cm}^{3}$ and 2.55 to 2.75 , respectively. The respective average compacted density in $\mathrm{g} / \mathrm{cm}^{3}$ (90 percent compaction) and specific gravity for each contaminated area were 1.64 and 2.70 for the UC offpile and subpile areas (11 samples), 1.46 and 2.69 for the UC tailings area (10 samples), and 1.51 and 2.70 for the NC area (9 samples). The estimated porosities for contaminated soils from the UC offpile and subpile areas, UC tailings area, and NC area were $0.39,0.46$, and 0.44 , respectively.

\subsubsection{Layer thickness}

Specific thicknesses of three discrete layers of contaminated materials were calculated for NC site materials, UC tailings and subpile materials, and UC offpile materials. Thicknesses for the contaminated layers were calculated based on estimated volumes of materials and their ultimate geometric locations in the disposal cell, with layers sequentially placed in increasing numerical order from bottom to top. Volumes of materials were determined from radiometric measurements and radiological analyses of soil samples and from boring and test pit material collected across the Slick Rock sites. Information on layer 
thicknesses can be found in Calculations 11-212-01-01 and 11-321-02-00 of Attachment 1.

\subsubsection{Radium-226 concentrations}

Average Ra-226 concentrations were estimated based on an assessment of radiometric measurements (hand-held and borehole gamma logs), and radiochemical and gamma spectroscopic measurements of contaminated material collected from surface soil samples, test pits, and boreholes within each subarea. Incremental Ra-226 depth profiles were constructed at each measurement grid point within the subareas. The average Ra-226 concentration for each subarea was determined by integrating the profiles over the volume contained between the topographical surfaces defining the ground surface and the excavation depth required to comply with EPA cleanup standards. Estimated design volumes are shown in Table 1.1 of Section 1.0 of this document.

\subsubsection{Ambient radon concentration}

An ambient radon concentration in air of $1.5 \mathrm{pCi} / \mathrm{L}$ was used for the RAECOM computer code. The code was based on 24-hr background air samples collected with continuous radon samplers in the vicinity of the Slick Rock sites (FBDU, 1977). However, preremedial action radon monitoring at the disposal site for four quarters (August 1990 through August 1991) using integrating Track-Etch detectors indicates that an ambient radon concentration of $0.5 \mathrm{pCi} / \mathrm{L}$ is more appropriate (DOE, 1991). Use of either radon concentration value will result in equivalent radon barrier design thickness determinations.

\subsection{EVALUATION OF RADON BARRIER}

The radon barrier was evaluated for compliance with the EPA radon flux standard of $20 \mathrm{pCi} / \mathrm{m}^{2} \mathrm{~s}$ using the above parameters in the RAECOM code. Only the high clay content earthen layer directly over the contaminated material was considered. A minimum thickness of 20 in $(0.51 \mathrm{~m})$ is needed on the topslopes of the disposal cell to achieve the $20 \mathrm{pCi} / \mathrm{m}^{2} \mathrm{~s}$ standard under worst-case conditions. Similar calculations for the sideslopes indicate that at least 26 in $(0.66 \mathrm{~m})$ of radon barrier is required if UC tailings are placed directly underneath the radon barrier. A minimum radon barrier thickness of 24 in $(0.61 \mathrm{~m})$ is required on the sideslopes, if $U C$ tailings material is placed $2.5 \mathrm{ft}(0.76 \mathrm{~m})$ away from the edge of the sideslopes. For added safety, however, UC tailings will be placed a minimum distance of $10 \mathrm{ft}(3 \mathrm{~m})$ (measured horizontally) away from the edge of the sideslope.

A sensitivity analysis was conducted for the Burro Canyon radon barrier design in accordance with TAD procedures (DOE, 1989). The 20-in $(0.51-\mathrm{m})$ radon barrier thickness calculated for the "average + or - SEM" (worst case) condition is less than the 24 -in $(0.61-\mathrm{m})$ barrier that will be constructed; therefore, the 
design of the disposal cell provides reasonable assurance of compliance with EPA standards.

6.5

SITE CLEANUP

Extensive field sampling and radiological surveys were conducted by several investigators to determine the extent and degree of contamination at the Slick Rock sites. Figure 6.1 shows the distribution of contaminated materials. Some of the areas shown in Figure 6.1 have been determined to be uranium ore deposits.

\subsubsection{Radiological site characterization}

Details of site characterization data are presented in Calculation 11-212-01-02 in Attachment 1. Measurements of background radioactivity near the Slick Rock sites and measurements of existing radiological site conditions are summarized in Table 6.1.

Table 6.1 Background radioactivity and radiological conditions at the Slick Rock sites

\begin{tabular}{lccc}
\hline \multicolumn{1}{c}{ Parameter } & Background & NC site & UC site \\
\hline Gamma exposure rate $(\mu \mathrm{R} / \mathrm{hr})^{\mathrm{a}}$ & 13 & 160 & 63 \\
Radon-222 (pCi/L) & 0.5 & 4.1 & 1.4 \\
Radon Flux (pCi $\left./ \mathrm{m}^{2} \mathrm{~s}\right)$ & $\mathrm{NA}$ & 240 & 70 \\
Radium-226 (pCi $/ \mathrm{g})^{\mathrm{b}}$ & 1.4 & 345 & 99 \\
\hline
\end{tabular}

${ }^{a} \mu \mathrm{R} / \mathrm{hr}$ - microroentgens per hour.

bVolume-weighted average.

NA-not applicable.

Approximately $621,000 \mathrm{yd}^{3}\left(475,000 \mathrm{~m}^{3}\right)$ of contaminated materials cover $69 \mathrm{ac}(28 \mathrm{ha})$ at the Slick Rock processing sites. This excludes the contaminated soil thinly dispersed over 17 ac (6.9 ha) in the floodplain area across the Dolores River from the UC sites where the DOE proposes to apply supplemental standards.

Additional areas of contamination outside the designated UC and NC sites were determined to be uranium ore deposits which will not be remediated (Attachment 1, Calculation 11-270-01-00).

Estimated design volumes for the various major contaminated materials are presented in Table 1.1 of Section 1.0. Depths of contamination range from less than $0.5 \mathrm{ft}(0.2 \mathrm{~m})$ for windblown areas east of the Dolores River to approximately 14 and $50 \mathrm{ft}(4$ and $15 \mathrm{~m})$ at the $N C$ and $U C$ tailings piles, respectively. The Ra-226 soil concentration at the NC and UC sites ranges from 


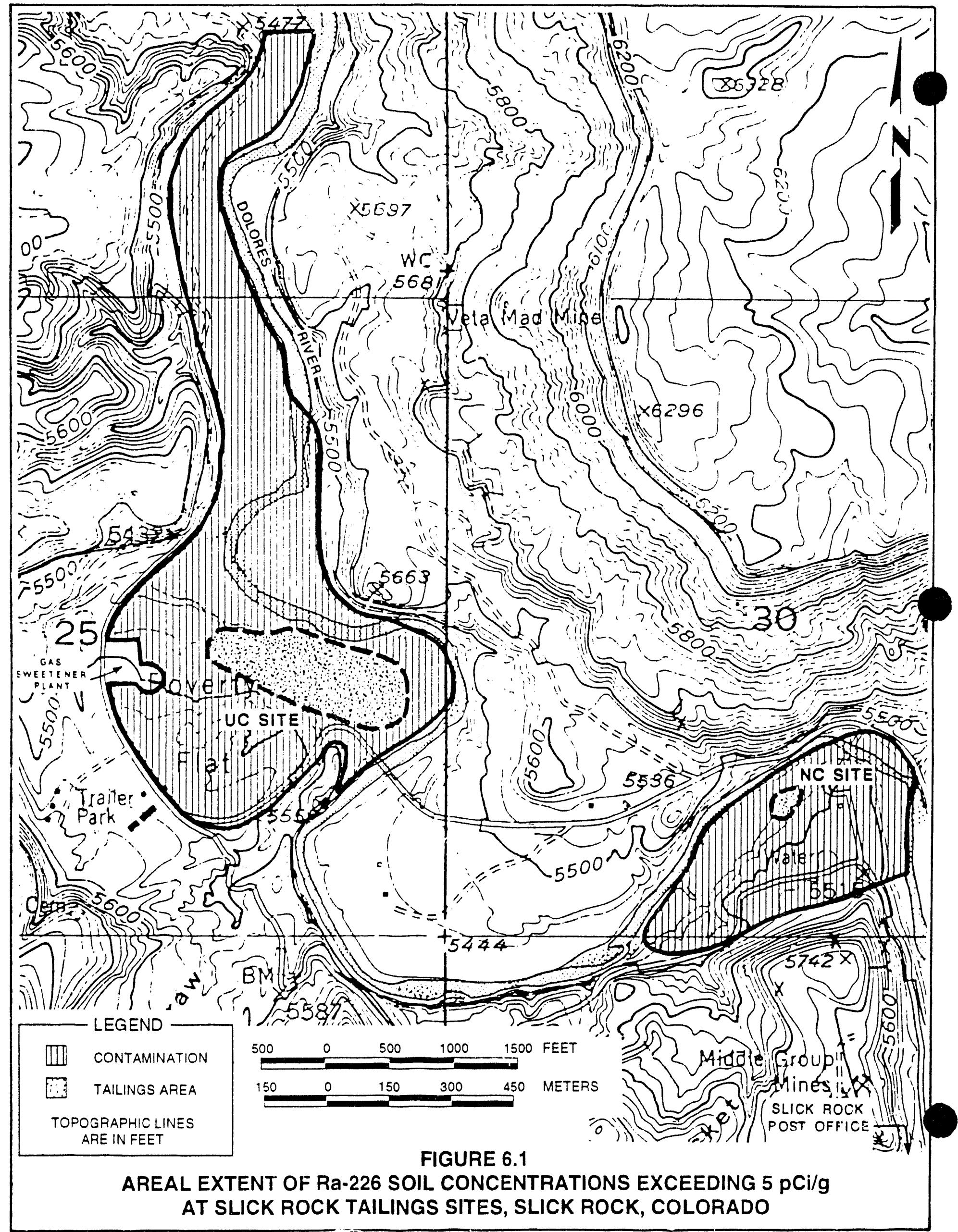


1 to $8903 \mathrm{pCi} / \mathrm{g}$, with a volume-weighted average of $345 \mathrm{pCi} / \mathrm{g}$ for the NC site materials, $135 \mathrm{pCi} / \mathrm{g}$ for the UC site tailings, and $35 \mathrm{pCi} / \mathrm{g}$ for the UC offpile and subpile materials.

\subsubsection{Standards for cleanup}

The DOE is committed to removing contaminated materials and placing them in an engineered, off-site disposal cell to meet all EPA standards in 40 CFR Part 192. Applying the supplemental standard provisions of 40 CFR Part 192 appropriate to vicinity properties will exclude the floodplain area across the Dolores River from the UC site from the remedial action. An appropriate application will be developed and submitted for NRC concurrence. The application will be based on the following conditions: limited long-term health impacts, presented by the low-level Ra-226 contamination dispersed over an estimated $17 \mathrm{ac}(6.9 \mathrm{ha})$ with an average concentration of $7.4 \pm 1.4 \mathrm{pCi} / \mathrm{g}$; human habitation of the area is unlikely because access to the site is limited by the river on one side and steep cliffs on the other; remedial action would be very costly due to necessary construction of a temporary bridge across the Dolores River; and long-term environmental harm from remedial action is probable if scarce riparian habitat is destroyed.

All disturbed areas on the processing site and vicinity properties will be restored to grade for adequate control of surface drainage. No contaminated material or buildings are now planned to be released for unrestricted use; decontamination would be achieved to levels that meet EPA standards, NRC limits, and guidelines and requirements of the UMTRA Project Environmental, Health, and Safety Plan (DOE, 1992b).

\subsubsection{Verification of cleanup}

Excavation control monitoring will be conducted during remedial action to prevent both inadequate underexcavation and costly overexcavation. Verification sampling will ensure that the $5 \mathrm{pCi} / \mathrm{g}$ and $15 \mathrm{pCi} / \mathrm{g}$ above background Ra-226 design standards are met for surface and subsurface soils. The verification survey will provide reasonable assurance of compliance with the standards.

Thorium-230 (Th-230) will be excavated and verified in accordance with the NRC-approved generic protocol for Th-230 cleanup and verification at UMTRA Project sites. This document is available at the UMTRA Project Office, Albuquerque Operations Office, Albuquerque, New Mexico.

The DOE and the TAC will conduct independent radiological and health/safety audits during remedial action to ensure that all activities are performed to meet federal, state, and local standards and guidelines. $\mathrm{QC}$ and $\mathrm{QA}$ requirements and procedures are in place to ensure that adequate cleanup and subsequent verification are properly implemented and documented (DOE, 1993b). 
Final verification surveys will document average Ra-226 (and Th-230, when applicable) concentrations in the top 6 -in $(0.2-\mathrm{m})$ layer of soil on all area grids less than or equal to $100 \mathrm{~m}^{2}$ at the site. Nine-plug, composite-surface soil samples will be collected above the water table for each grid area less than or equal to $100 \mathrm{~m}^{2}$ and analyzed by gamma spectroscopy or other analytical methods approved by the UMTRA Project Office to verify compliance with EPA standards.

In addition, a nine-point composite in situ gamma measurement technique may be used in windblown-contaminated areas. This hand-held verification protocol will be site-specific and must be app, oved by the DOE UMTRA Project Office. The RTRAK mobile gamma detection unit may be used to verify contaminated areas that are too large to sample by hand methods. Verification sampling for Th-230 will be performed in accordance with NRC-approved generic protocol for Th-230 cleanup and verification at UMTRA Project sites.

If areas with cobbly soils are encountered during the cleanups and verifications, an NRC-approved procedure ("Soil Verification Using Cobbles-to-Fines Corrections") may be implemented at the site for bulk radionuclide concentration determinations, excavation depth control, and site verification. This approved procedure provides an appropriate quantitative method for cleanup and verification of soils that contain a high percentage of gravels, cobbles, and boulders.

\section{SUMMARY AND CONCLUSION}

The DOE is committed to cleaning up the Slick Rock sites in accordance with EPA standards, NRC guidelines, and UMTRA Project health and safety requirements. The disposal cell and radon barrier design will reduce the surface radon flux to levels below the EPA standards defined in 40 CFR $\$ 192.02$ (b). Actual radon flux levels will be verified upon completion of the disposal cell to demonstrate compliance with 40 CFR Part 61, Subpart T, "National Emission Standards for Radon Emissions from the Disposal of Uranium Mill Tailings." Appropriate supplemental standards will be developed that will exclude the floodplain area across the river from the UC site from remedial action. These supplemental standards will be submitted for NRC approval. To date, data have been collected, verified, and analyzed to provide a reasonable preliminary design; subsequent refinements of the final design will ensure the fulfillment of DOE's commitment. 


\subsection{LIST OF CONTR!BUTORS}

The following individuals contributed to the preparation of this report.

\begin{tabular}{ll}
\hline Name & Contribution \\
\hline M. B. Leaf & Overall document responsibility \\
G. Lindsey & Geology, seismicity \\
K. Monks & Hydrology, hydrogeology \\
J. Crain & $\begin{array}{l}\text { Document coordinator; engineering, geotechnical, } \\
\text { surface water hydrology }\end{array}$ \\
A. Meijer & Geochemistry \\
W. James, G. Simiele & Radiology \\
L. Keith, C. Slosberg & Text processing \\
E. Bond, J. Brannan, B. Harvey, & Graphic design \\
E. Wagner & Technical editing and document production \\
D. Thalley, J. Torline & coordination \\
\hline
\end{tabular}




\subsection{REFERENCES}

ASTM (American Society for Testing and Materials), 1991. "Soil and Rock, Building Stones, Geotextiles," Annual Book of ASTM Standards, Volume 04.08, Philadelphia, Pennsylvania.

Campbell, K. W., 1981. "Near-Source Attenuation of Peak Horizonal Acceleration," in Bulletin of the Seismological Society of America, Vol. 71, pp. 2039-2070.

Cooley et al. (M. E. Cooley, J. W. Hershbarger, J. P. Akers, and W. F. Hardt), 1969. Regional Hydrogeology of the Navajo and Hopi Reservations, Arizona, New Mexico, and Utah, U.S. Geological Survey Professional Paper 521-A, Washington, D.C.

Daniel B. Stephens \& Associates, Inc., 1991. Laboratory Analysis of Soil Hydraulic. Properties of the Burro Canyon Rock Samples, prepared for the U.S. Department of Energy, UMTRA Project Office, Albuquerque Operations Office, Albuquerque, New Mexico.

DOE (U.S. Department of Energy), 1993a. Environmental Assessment of Remedial Action at the Slick Rock Uranium Mill Tailings Sites, Slick Rock, Colorado, DOE/EA-0339, draft, prepared by the U.S. Department of Energy, UMTRA Project Office, Albuquerque Operations Office, Albuquerque, New Mexico.

DOE (U.S. Department of Energy), 1993b. UMTRA Project Quality Assurance Plan, UMTRA-DOE/AL-185, Revision 4, prepared oy the U.S. Department of Energy, UMTRA Project Office, Albuquerque Operations Office, Albuquerque, New Mexico.

DOE (U.S. Department of Energy), 1992a. Software Program for Environmental Analysis and Reporting (SPEAR) System, U.S. Department of Energy, UMTRA Project Office, Albuquerque Operations Office, Albuquerque, New Mexico.

DOE (U.S. Department of Energy), 1992b. UMTRA Project Environmental, Heaith, and Safety Plan, UMTRA-DOE/AL-150224.0006, DOE UMTRA Project Office, Albuquerque Operations Office, Albuquerque, New Mexico.

DOE (U.S. Department of Energyi, 1991. Analysis of Infiltration through a Clay Radon Barrier at an UMTRA Disposal Cell, UMTRA-DOE/AL-400667.0000, prepared by the U.S. Department of Energy, UMTRA Project Office, Albuquerque Operations Office, Albuquerque, New Mexico.

DOE (U.S. Department of Energy), 1989. Technical Approach Document, UMTRA-DOE/AL-050425.0002, DOE UMTRA Project Office, Albuquerque Operations Office, Albuquerque, New Mexico. 
DOE (U.S. Department of Energy), 1986. Comparative Analysis of Disposal Site Alternatives Report for the UMTRA Project Slick Rock Site Located at Slick Rock, Colorado, DOE UMTRA Project Office, Albuquerque Operations Office, Albuquerque, New Mexico.

EPA (U.S. Environmental Protection Agency), 1989. Statistical Analysis of Ground-Water Monitoring Data at RCRA Facilities-Interim Final Guidance, EPA/530-SW-89-026.

EPA (U.S. Environmental Protection Agency), 1986. Guidelines for Ground-Water Classification Under the EPA Ground-Water Protection Strategy, final draft, EPA Office of Ground-Water Protection, Office of Water, Washington, D.C.

FBDU (Ford, Bacon \& Davis Utah, Inc.), 1981. Engineering Assessment of Inactive Uranium Mill Tailings, Slick Rock Sites, Slick Rock, Colorado, DOE/UMT-0115, FBDU 360-07, UC 70, prepared by FBDU, Salt Lake City, Utah, for the U.S. Department of Energy, UMTRA Project Office, Albuquerque Operations Office, Albuquerque, New Mexico.

FBDU (Ford, Bacon \& Davis Utah Inc.), 1977. Engineering Assessment of the Inactive Uranium Mill Tailings, Slick Rock, Colorado, DOE/UMT-0115, prepared by FBDU, Salt Lake City, Utah, sor the U.S. Department of Energy, Albuquerque Operations Office, Albuquerque, New Mexico.

Freeze, R. A., and J. A. Cherry, 1979. Ground Water, Prentice-Hall, Inc., Englewood Cliffs, New Jersey.

JEG (Jacobs Engineering Group Inc.), n.d. Albuquerque Operatiuns Manual, standard operating procedures, prepared by Jacobs Engineering Group Inc., Albuquerque, New Mexico, Albuquerque Operations Office, Albuquerque, New Mexico.

Lindsey et al. (C. G. Lindsey, L. W. Long, and C. W. Begej), 1982. Long-Term Survivability of Riprap for Armoring Uranium Mill Tailings and Covers: $A$ Literature Review, U.S. Nuclear Regulatory Commission, NUREG/CR-2642, Washington, D.C.

NGDC (National Geophysical Data Center), 1989. "Dry Flats site, Colorado: Epicentral Compilation for Magnitude $M=4$ and $I=1, "$ Boulder, Colorado.

NOAA (National Oceanic and Atmospheric Administration), 1977. Hydrometeorological Report No. 49, Probable Maximum Precipitation Estimates - Colorado River and Great Basin Drainages, Silver Spring, Maryland.

NRC (U.S. Nuclear Regulatory Commission), 1989. Standard Format and Content for Documentation of Remedial Action Selection at Title 1 Uranium Mill Tailings Sites, Staff Technical Position, February 24, 1989. 
NRC (U.S. Nuclear Regulatory Commission), 1985. Standard Review Plan for the UMTRCA Title I Mill Tailings Remedial Action Plans, U.S. Nuclear Regulatory Commission, Washington, D.C.

NRC (U.S. Nuclear Regulatory Commission), 1984. Radon Attenuation Handbook for Uranium Mill Tailings Cover Design, NUREG/CR-3533, U.S. Nuclear Regulatory Commission, Washington, D.C.

NRC (U.S. Nuclear Regulatory Commission), 1983. "Documentation and User's Guide: UNSAT2 - Variable Saturated Flow Model," NUREG/CR 3390, U.S. Nuclear Regulatory Commission, Washington, D.C.

PMET (Pittsburgh Mineral \& Environmental Technology), 1990. Chemical and Mineralogical Characterization of Soil Samples from Slick Rock, CO IBurro Canyon), prepared by Wolfgang Baum of PMET, for Jacobs Engineering Group Inc., Albuquerque Operations Office, Albuquerque, New Mexico.

PNL (Pacific Northwest Laboratory), 1980. "Model Assessment of Contaminant Seepage from Buried Uranium Mill Tailings," Pacific Northwest Laboratory, Richland, Washington.

Shawe et al. (D. R. Shawe, G. C. Simmons, and N. L. Archibold), 1968. Stratigraphy of Slick Rock District and Vicinity, San Miguel and Dolores Counties, Colorado, U.S. Geological Survey Professional Paper 576-A, Washington, D.C.

Stephenson, D., 1979. Rockfill in Hydrologic Engineering, Elsevier Scientific Publishing Company, New York, New York.

Stevens et al. (M. A. Stevens, D. B. Simons, and G. L. Lewis), 1976. "Safety Factors for Riprap Protection," in Journal of Hydraulic Engineering. American Society of Civil Engineers.

USACE (U.S. Army Corps of Engineers), 1970a. Laboratory Soils Testing, EM-1110-21906, U.S. Department of the Army, Office of the Chief of Engineers, Washington, D.C.

USACE (U.S. Army Corps of Engineers), 1970b. Hydraulic Design of Flood Control Channels, EM-1110-2-1601, U.S. Department of the Army, Office of the Chief of Engineers, Washington, D.C.

USACE (U.S. Army Corps of Engineers), 1965. "Hydraulic Design of Spillways," EM11102-1603, U.S. Depariment of the Army, Office of the Chief of Engineers, Washington, D.C.

\section{CODE OF FEDERAL REGULATIONS}

40 CFR Part 192, Health and Environmental Protection Standards for Uranium and Thorium Mill Tailings, U.S. Environmental Protection Agency, 1993. 


\section{FEDERAL REGISTER}

52 FR 36000, Standards for Remedial Actions at Inactive Uranium Processing Sites;

Proposed Rule, September 24, 1987.

\section{UNITED STATES CODE}

42 USC $\$ 7901$ et. seq., Uranium Mill Tailings Radiation Control Act, November 8, 1978.

\section{END DATE $4 / 19 / 94$}

